Florida International University FIU Digital Commons

\title{
Cubanía and Caridad : a comparative analysis of Cuban Marianism
}

\author{
Alma DeRojas \\ Florida International University
}

DOI: $10.25148 /$ etd.FI14062246

Follow this and additional works at: https://digitalcommons.fiu.edu/etd

Part of the Latin American Studies Commons

\section{Recommended Citation}

DeRojas, Alma, "Cubanía and Caridad : a comparative analysis of Cuban Marianism" (2004). FIU Electronic Theses and Dissertations. 2776.

https://digitalcommons.fiu.edu/etd/2776

This work is brought to you for free and open access by the University Graduate School at FIU Digital Commons. It has been accepted for inclusion in FIU Electronic Theses and Dissertations by an authorized administrator of FIU Digital Commons. For more information, please contact dcc@fiu.edu. 
FLORIDA INTERNATIONAL UNIVERSITY

Miami, Florida

\title{
CUBANÍA AND CARIDAD: \\ A COMPARATIVE ANALYSIS OF CUBAN MARIANISM
}

\author{
A thesis submitted in partial fulfillment of the \\ requirements for the degree of \\ MASTER OF ARTS \\ in \\ LATIN AMERICAN AND CARIBBEAN STUDIES \\ by
}

Alma DeRojas

2004 
To: $\quad$ Dean R. Bruce Dunlap

College of Arts and Sciences

This thesis, written by Alma DeRojas, and entitled Cubanía and Caridad: A Comparative Analysis of Cuban Marianism, having been approved in respect to style and intellectual content, is referred to you for judgment.

We have read this thesis and recommend that it be approved.

Sarah Mahler

Lisandro Pérez

Terry Rey, Major Professor

Date of Defense: March 17, 2004

The thesis of Alma DeRojas is approved.

Dean R. Bruce Dunlap College of Arts and Sciences

Dean Douglas Wartzok University Graduate School

Florida International University, 2004 


\section{ACKNOWLEDGMENTS}

This thesis would not have been possible without the guidance of my major professor, Dr. Terry Rey. I would also like to thank the other members of my committee, Dr. Lisandro Pérez and Dr. Sarah Mahler, for their support. I am especially grateful for the travel grant I received from the Cuban Research Institute to conduct my research in Cuba. Finally, I wish to dedicate this thesis to all those Cubans, both in Miami and on the island, who helped me to understand the power and significance of La Caridad. 
ABSTRACT OF THE THESIS

CUBANÍA AND CARIDAD:

A COMPARATIVE ANALYSIS OF CUBAN MARIANISM

by

Alma DeRojas

Florida International University, 2004

Miami, Florida

Professor Terry Rey, Major Professor

The primary purpose of the thesis was to compare the present cultural and political significance of La Virgen de la Caridad del Cobre for Cubans on the island and in exile, focusing on the Virgin's role as a symbol of national identity. The secondary purpose was to explore the historical evolution of the Virgin's myth through an analysis of documents and scholarly literature. In addition to participant observation, interviews of 50 Cubans were conducted at La Caridad's shrines in Cuba and Miami. These interviews reveal that the Virgin's symbol continues to meet the religious, economic, political, and social needs of Cubans everywhere. Furthermore, her symbol reveals insights into the nature of Cuban national identity. The thesis concludes that the myth of La Caridad, like Cuban identity itself, is dynamic, complex, multi-dimensional, and fluid. 


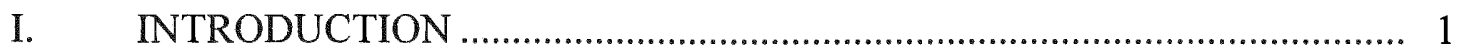

Research Question and Hypothesis............................................................. 2

Theoretical Perspective ............................................................................ 3

Significance of Study ............................................................................. 4

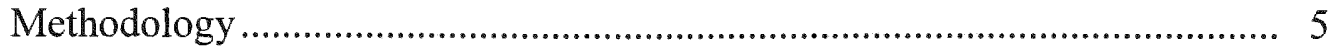

II. LITERATURE REVIEW ..................................................................... 7

III. THEORIZING THE VIRGIN'S VENERATION ..................................... 11

Symbolic Flexibility................................................................................ 11

Symbolic Liberation............................................................................. 15

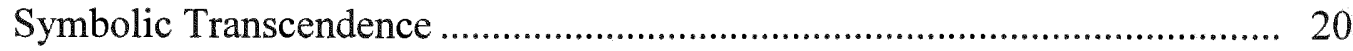

The Cuban Spirit .......................................................................................... 23

IV. OUR LADY OF CUBA LIBRE ..................................................... 30

Yo soy la Virgen de la Caridad .................................................................... 34

The Royal Slaves and the Virgin ........................................................... 36

La Virgen Mambisa................................................................................... 41

¡Virgen de la Caridad, salva a Cuba! ........................................................... 45

Reina de la República ................................................................................ 52

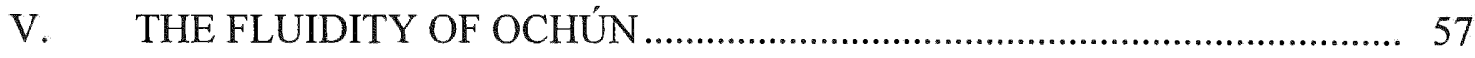

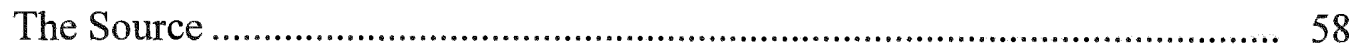

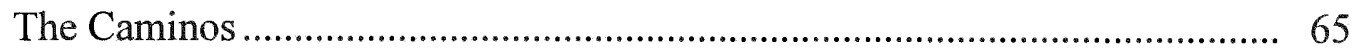

The Caminos of Cubanía ....................................................................... 70

VI. A COMPARATIVE ANALYSIS OF LA CARIDAD'S CURRENT

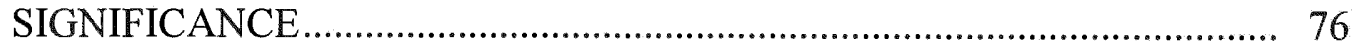

Miami: September 7 and 8, 2003 ........................................................ 76

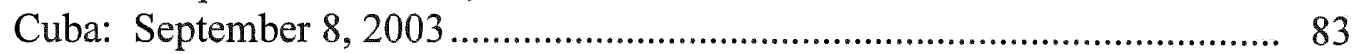

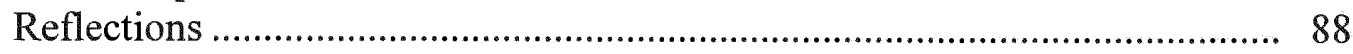

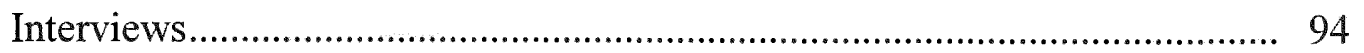

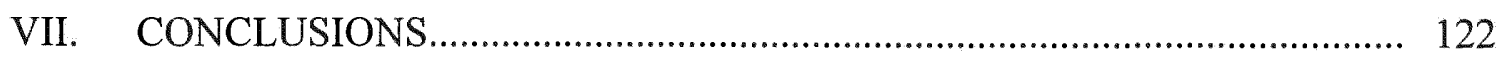

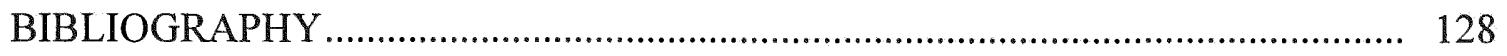

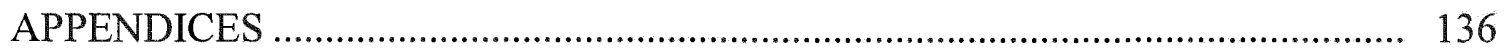




\section{CHAPTER 1:}

\section{INTRODUCTION}

On September 8, 2002, 9,000 exiled Cubans gathered in Miami's American Airlines Arena to celebrate the feast day of Cuba's patroness, La Virgen de la Caridad del Cobre. ${ }^{1}$ Meanwhile in Havana thousands of Cubans accompanied an image of La Caridad in a twelve-block procession led by their Archbishop. Throughout the island, similar processions and Masses were held in honor of the Virgin, which were each attended by some dissidents and human rights activists, and consequently by state security agents. In both Miami and Havana, cries of ¡Cuba libre! emanated from the crowds, yet in Havana, this cry for democracy resulted in the arrest of three dissidents (Fernandes). Fear of the political power of these celebrations even led Cuban authorities to prohibit a similar procession in the province of Villa Clara. Thousands still gathered, however, to hear the homily of Father Felix Ferre. Although his main message was to inspire Cubans to be the protagonists of their own history, he also emphasized that "Our Lady of Charity is the mother of all Cubans, inside and outside the country" (Fernandes).

As these celebrations on both sides of the Florida Straits reveal, La Virgen de la Caridad continues to affect the lives of Cubans around the world, nearly four hundred years after her statue was discovered in the Bay of Nipe. This thesis explores comparatively the symbolic significance of La Virgen de la Caridad del Cobre for Cubans in the diaspora and on the island, focusing on the Virgin's role as a symbol of national identity and her contested representations in Cuban politics. My primary

\footnotetext{
${ }^{1}$ Attendance figure given in the Spanish-language newspaper of the Archdiocese of Miami, La voz católica.
} 
purpose is to compare the present cultural and political significance of La Caridad for Cubans on and off the island, while my secondary purpose is to explore the historical evolution of the Virgin's myth.

As a national symbol of Cuba, the Virgin of Charity has been appropriated by various sectors of Cuban society and the Cuban exile community through the centuries. While I recognize that La Caridad's symbol does not appeal to all Cubans, especially to the growing number of Protestants on the island today, her appropriation by diverse sectors of Cuban society reveals her wide appeal. ${ }^{2}$ Specifically, I focus on the following groups: cobreros $^{3}$ of the eighteenth century, mambises ${ }^{4}$ of the independence wars, exiles of the twentieth century, followers of Santería (both on and off the island), and Cubans on the island today. For each group I analyze not only how the appropriation of the Virgin's symbol has met certain needs, but also how she is a symbol of cubania, or the Cuban spirit created by the desire to be Cuban, regardless of geographical, social, political, and cultural boundaries.

Research Question and Hypothesis

My research question consists of two equally important aspects:

1) How has the symbol of La Caridad evolved over the centuries?

2) How is the symbol of La Caridad a reflection of la cubania, and how does this differ among Cubans on the island and in exile? I hypothesize that:

2 According to the U.S. Department of State's "International Religious Freedom Report: Cuba," membership in Protestant churches on the island is currently estimated at 500,000 people, a significant percentage of the total population of 11 million.

${ }^{3}$ Cobreros were residents of El Cobre, a copper-mining village near Santiago de Cuba that was founded by the Spaniards in the sixteenth century. Today El Cobre is the site of the Virgin's shrine.

${ }^{4}$ Mambises were rebel Cuban soldiers who fought against Spain in the nineteenth-century independence wars. 
1) The symbol of La Caridad has evolved and diversified to meet the needs of devoted Cubans. Such needs may be religious, social, political, or economic, and depend primarily on factors of class and race. These factors explain the radical differences in devotion on the island and in exile.

2) Just as the symbol of La Caridad has evolved over time, so too have notions of Cuban identity. The fluidity of her symbol thus reflects the fluidity of cubania. By exploring the different dimensions of devotion to the Virgin, one can simultaneously explore the many ways to be "Cuban." As Fernando Ortiz writes, to possess cubania entails more than the possession of a Cuban passport or birth certificate; the desire to be Cuban is also essential. I hypothesize that this desire to be Cuban is expressed more intensely in exile than on the island because of the psychological anguish of separation from one's homeland. Consequently, the association between la cubanía and La Caridad will be stronger in exile.

\section{Theoretical Perspective}

Using a theoretical framework based on the fluidity of symbols, the role of religious needs, and the power of desire, my thesis examines the evolving significance of the Virgin of Charity. Principal theoretical sources include the theories of Max Weber on religious needs, Mircea Eliade on religious symbols, Thomas Tweed on diasporic religion, Fernando Ortiz on the connection between desire and la cubania, and Stuart Hall on the fluidity of identity. Oriented by the perspective of Jorge Duany, who emphasizes the dynamic and fluid nature of Cuban identity, my exploration of the Virgin's myth demonstrates both the power and fluidity of symbol and identity, of La 
Caridad and la cubanía. As a symbol of la cubanía, La Caridad encarnates this desire to be Cuban; in a sense, she is a visual representation of the Cuban spirit.

Significance of Study

This study is primarily significant for filling gaps in the literature on La Caridad. The two most important works on the Virgin are Thomas Tweed's Our Lady of the Exile: Diasporic Religion at a Cuban Catholic Shrine in Miami and Olga Portuondo Zúñiga's La Virgen de la Caridad del Cobre: Símbolo de cubania, each of which fails to address certain essential aspects of the Virgin's myth. While Tweed ignores La Caridad's significance in today's Cuba, Portuondo Zúñiga ignores her significance in exile. My thesis attempts to address this gap by conducting a comparative analysis of devotion to the Virgin in exile and on the island.

On a personal note, my thesis is significant as another aspect of my academic journey to understand the meaning of cubania. As the daughter of a Cuban father and an Irish-American mother, I have a personal interest in both the exile experience and the concept of "Cuban" identity. Much of my academic work has been motivated by my desire to explore what it means to be Cuban, including an undergraduate honors thesis at Susquehanna University on the expression of cubania in Cuban American literature of exile. In a sense, this thesis is a continuation of my quest to understand cubania. Instead of focusing on how the Cuban spirit is expressed on the page, however, I now seek to explore how it is encarnated in a religious symbol. Although I am Catholic, I am not especially devoted to the Virgin of Charity. I do recognize, however, the cultural power of her symbol. This thesis is therefore not intended to be a theological exploration of the 
Virgin, but an ethnographical analysis of her ability to meet the needs of her devotees and to symbolize Cuban identity.

\section{Methodology}

In order to understand the current symbolic significance of La Caridad for Cubans, I conducted a comparative analysis through participant observation at the Virgin's shrines in Miami, Florida and El Cobre, Cuba, as well as at her feast day Mass in Miami on September 8, 2003. In addition, I conducted fifty structured interviews of devoted Cubans, 25 in Miami and 25 in Cuba. Interviewees were recruited at the shrines on different days and times. Although this method does not assure a random sample, it did result in a diverse group in terms of gender, race, class, place of origin, and age.

Readers must be aware that my sample was restricted to those Cubans who visit the Virgin's shrines in Miami and Cuba. Therefore, my analysis primarily focuses on her current significance for devoted Cubans. Clearly not all Cubans have faith in the Virgin of Charity, especially atheists, as well as the more than half a million Protestants who currently live on and off the island. While the Marxist and Protestant perspectives on the Virgin are equally as valid as Catholic and Afrocuban interpretations of La Caridad, I have chosen to focus on her devoted followers. In light of Cuba's growing Protestant presence, the Virgin of Charity's role as "the Mother of all Cubans" is increasingly

contested, yet in the minds of her spiritual children, La Caridad is a powerful symbol of Cuban national identity. As often as possible, I use quotes from my interviewees in my analysis of La Caridad's current significance. Their words clearly reveal both the strength of her cult and the power of her symbol. 
The secondary goal of my thesis, a historical analysis of the Virgin's significance, was achieved through a review of scholarly literature on La Caridad and an analysis of documents and periodicals, including Miami Herald articles on her feast day celebrations from 1980 to 2003. While the historical aspect of the Virgin is not my primary focus, an exploration of her evolution is key to understanding her current political and cultural significance. 


\section{CHAPTER 2:}

\section{LITERATURE REVIEW}

The myth of the Virgin of Charity traces its roots back to 1612 , when a slave and two Indian brothers discovered floating in the Bay of Nipe a wooden statue of Mary inscribed with the following words: Yo soy la Virgen de la Caridad. ${ }^{5}$ The first written account of this apparition is a 1687 declaration by Juan Moreno, one of the three people who discovered the statue, to officials of the Catholic Church (Portuondo Zúniga 30). After Moreno's account, written versions of La Virgen's story were scarce for the next century, for her cult was still predominantly regional and had not yet secured a place in national Cuban consciousness. The few existing accounts are historical church documents, including one written by Father Onofre de Fonseca in 1703 and another by Father Julián Joseph Bravo in 1766 (Portuondo Zúñiga 30). Subsequent versions written in the nineteenth century all relied heavily on Fonseca's and added nothing of great importance.

Scholarly interpretations of La Caridad did not begin until the twentieth century. Academic interest in the Virgin was sparked in the 1920s when Irene Aloha Wright wrote about the similarities between the Virgins of Charity in El Cobre, Cuba and Illescas, Spain in the magazine Archivos del Folklore Cubano. This awakened the interest of the prominent Cuban sociologist Fernando Ortiz, who began to write, without completing, a book about La Caridad (Portuondo Zúñiga 28). A significant contribution to the literature on the myth was later added in 1939 by José Juan Arrom's essay, La Virgen del

\footnotetext{
${ }^{5}$ Through the years, the ethnic identities of the three men have changed, an element of the myth's fluidity that will be explored in greater detail in the section of historical analysis.
} 
Cobre: historia, leyenda y simbolo, which explores the Virgin's syncretic relationship with the Taíno deity Atabey and the Yoruba goddess Ochún. Arrom's essay represents the beginning of the focus on the syncretic aspects of the myth; it led the way for such scholars as Rómulo Lachatañere to write about the relation of La Virgen with Ochún, the Santería goddess of love, fertility, and rivers (Portuondo Zúñiga 29).

While Arrom and Lachatañere focus on the syncretic relationship of La Caridad with Atabey and Ochún, the Cuban historian Leví Marrero explores an important historical aspect in Los esclavos y la Virgen del Cobre: Dos siglos de lucha por la libertad, in which he focuses on the Virgin's role in the cobreros' struggle to achieve freedom. This historical aspect of the myth is further explored by Maria Elena Díaz in The Virgin, the King, and the Royal Slaves of El Cobre, published in 2000. Díaz's study of the Virgin's role in El Cobre represents a significant contribution to the literature, for it is not only a story of La Caridad, but it is also a wider account of how identity can be legitimized through the appropriation of symbols. Furthermore, the book is significant for its focus on the slaves of El Cobre, which offers a perspective "from below" and a story that is often forgotten by Cubans today. In the words of Díaz, it is a "total history" of a "people without history" that explores the cultural, social, political, and economic aspects of El Cobre and the town's role in the development of the Virgin's myth.

A highly significant contribution to the literature is La Virgen de la Caridad del Cobre: Símbolo de cubania, written in 1995 by Olga Portuondo Zúñiga. Primarily a historical analysis, the work is significant because it offers a comprehensive overview of the Virgin's evolution. Although Portuondo Zúñiga rightly believes that the Virgin is a 
symbol of cubania, she ignores La Caridad's evolution in exile, probably due to the fact that she lives on the island.

For an understanding of La Virgen's significance in exile, Thomas Tweed's Our Lady of the Exile: Diasporic Religion at a Cuban Catholic Shrine in Miami is essential. In this sociological analysis of the Virgin's shrine in Miami, Tweed successfully captures the importance of La Caridad for exiled Cubans in Miami by examining her place in exilic Cuban nationalism. However, just as Portuondo Zúñiga ignores Miami, Tweed ignores Cuba, limiting his ethnographic analysis to the significance of the Virgin in exile. In order to understand the power of the myth, clearly one must examine its evolution both on the island and in the exile community.

One must also examine the syncretic relationship between La Caridad and Ochún in order to appreciate the diverse aspects of the myth. In addition to Lachatañere's work, other significant works on Ochún include Lydia Cabrera's Yemayá y Ochún, a general overview of the two goddesses, and Osún Across the Waters: A Yoruba Goddess in Africa and the Americas, a collection of essays, edited by Joseph M. Murphy and MeiMei Sanford, that explores the importance of Yoruba images in negotiating social identity and political power in both Africa and the African diaspora. Other works include a recent essay by Miguel de La Torre that offers an analysis of the syncretic relationship between Ochún and La Caridad. In "Ochún: (N)either the (M)Other of All Cubans (n)or the Bleached Virgin," he writes that the Virgin/Ochún "has the potential to inspire a theology of reconciliation for the Cuban community of Miami, Florida and La Habana, Cuba" (838). Thus De la Torre believes that this syncretic symbol "can serve as a catalyst for reconciling the two Cubas" (838). Although I agree that the Virgin/Ochún can aid in the 
process of reconciliation between Cubans on and off the island, De la Torre's belief that there are "two Cubas" is simplistic. As the following pages will demonstrate, national identity is fluid and not so easily divisible into two neat categories based solely on geography.

In all, the literature on La Virgen de la Caridad lacks a singular analysis of the significance of her symbol on both sides of the Florida Straits. Through an historical analysis of both the Virgin's role among both the cobreros and mambises and her syncretic relationship with Ochún, followed by a comparative analysis of her current role among exiles, santeros, and Cubans on the island, I hope to fill this gap in the literature. Before conducting my analysis, however, a theoretical exploration of the cult of the Virgin Mary in the Americas is necessary. 


\section{CHAPTER 3:}

\section{THEORIZING THE VIRGIN'S VENERATION}

This chapter theorizes Cuban devotion to the Virgin of Charity. Cuba's veneration of the Virgin is not unique. Throughout the world, the Virgin Mary is venerated in various forms. Every year, for instance, millions of pilgrims visit Marian shrines such as Lourdes, Fatima, and Medjugorje. As the mother of God, Mary's maternal presence fills the Christian faithful with a sense of confidence, hope, inner strength, and inspiration. As Jim McManus writes in All Generations Will Call Me Blessed, Mary "offers a calm vision and a reassuring word to modern people, torn as they often are between anguish and hope" (95). Thus the spiritual role of Mary as the Mother of Jesus cannot be underestimated. However, my focus on the Virgin is not theological, but ethnographic, as I analyze Mary as a symbol for a particular ethnic group.

Symbolic Flexibility

The veneration of Mary has been particularly strong in Latin America ever since Christopher Columbus arrived with a gilded banner of Mary attached to the Santa Maria. Thus from the beginning of Marian devotion in the New World, the Virgin in her various forms has been associated with political agendas. For example, during the conquest of Mexico, the soldiers of Hernán Cortés carried a banner of Mary as they marched in their quest to conquer the country (Narbutas 13). In a sense, the Virgin served as a means to legitimize the power that Cortés craved, thus revealing one aspect of the characteristic duality of Latin American Marianism. As Terry Rey writes in Our Lady of Class Struggle, Marian devotion in Latin America is characterized by a "legitimization/liberation duality" (4). While dominant figures such as Cortés have 
manipulated the Virgin's symbol to legitimize their power, the suppressed have often found in her the inspiration for their struggles of liberation. As will be demonstrated in my historical analysis, the liberating power of the Virgin is a key aspect of La Caridad's evolution.

In general, the legitimization/liberation duality of Marian devotion is due to the differing needs of the faithful. In the words of Rey, "how religious symbols are interpreted, manipulated, and used is chiefly dictated by the needs or agenda of a group or individual" ("The Politics of Patron Sainthood in Haiti" 525). This association between religion and needs was first developed by Max Weber in The Sociology of Religion, in which he writes that the religion of the privileged springs from their need to legitimize their power; in a sense, they turn to religion for "the psychological reassurance of legitimacy" (Weber 107). The religion of the "disprivileged," on the other hand, springs from four basic needs: release from suffering; just compensation; "a hunger for worthiness"; and "saints, heroes, or functional gods" in order to deal with the struggles of daily life (103). In fact, Weber believes that the veneration of these saints constitutes "the real religion of the masses in everyday life" (104). This supports Rey's position that Catholicism in Latin America "is in reality the cult of the Virgin Mary" ("The Virgin's Slip is Full of Fireflies"" 956). In a Weberian sense, the veneration of the Virgin of Charity is "the real religion" of Cubans, for she serves as a functional god who enables Cubans to deal with daily struggles.

Due to the differing needs of the faithful, the Virgin Mary can be interpreted in a variety of ways. Thus the needs of the faithful, whether they be political, religious, economic, or social, "represent one of the driving forces behind the diversity of 
interpretations of the symbol of the Virgin Mary" (Rey, "The Virgin's Slip is Full of Fireflies" "965). This diversity of interpretations, as well as the sometimes conflicting needs of the faithful, reveals that symbols such as the Virgin are often contested. Therefore, the Virgin Mary can be interpreted as "a hotly contested symbol that takes on a host of causes and responds to the needs of both the dominant to dominate and the subjugated to resist" (957). Although the Virgin of Charity has often been interpreted as a means to unify Cubans, my analysis of her symbolic significance will reveal that La Caridad is indeed a contested symbol, due to the different interpretations and conflicting needs of Cubans.

The diversity of symbolic interpretations of the Virgin is extensive throughout Latin America, and reflects the differing needs of those who embraced her power as either a tool of oppression or liberation. During the Central and South American independence wars, for example, the rebels' principal need was political liberation, the inspiration for which they often found in the Virgin. Some examples of Mary's association with liberation movements include the proclamation of Chile's Virgin of Carmel as the Protectress of the Armed Forces, of Guatemala's Our Lady of the Rosary as Patroness of the Freedom Fighters in 1821, and of Uruguay's Blessed Virgin of the Thirty-Three as Patroness of the Rebel Army in 1825 (Narbutas 138). Perhaps the most famous association of the Virgin with political liberation is Mexico's Hidalgo Revolt of 1810 , in which an image of the Virgin of Guadalupe led the rebel soldiers in battle. Consequently, Guadalupe, like all forms of the Virgin who have been associated with independence movements, has since been associated with national identity, yet another 
facet of Mary's symbolic power. When placed in this historical context, the role of Cuba's Virgin of Charity in the nineteenth-century independence wars is not unique.

The association between the Virgin and liberation continued in the twentieth century, as disprivileged people in such countries as Brazil and Haiti often turned to the Virgin for inspiration in their struggles against social injustice. ${ }^{6}$ At the same time, the Virgin has continued to be used by the elite, including Latin American dictators, as a means of domination. However she is interpreted, the point remains that the power of Mary in Latin America, and throughout the world, is due to the fact that her symbol can be appropriated to meet the needs of all. As Stafford Poole writes in Our Lady of Guadalupe, the symbol of Mexico's patroness will endure "because it can be interpreted and manipulated by succeeding generations to meet the needs of the Mexican people" (225). Like Caridad for Cubans, Guadalupe is one of the most powerful national symbols of Mexican identity. Although Poole questions the historical reality of the myth of Guadalupe, he recognizes that her power is symbolic. In a sense, historical reality does not matter for those who believe in the symbol. Although "a historical woman obviously dwells at the root of this whole pheonomeon," the power of the Virgin Mary clearly resides in the plasticity of her image, thus enabling the Christian imagination "to create widely different Marian symbols and theologies in relation to spiritual and social needs" not only in Latin America, but around the world (E. Johnson).

Whether one examines the connection between, for example, Our Lady of Fatima and cold-war opposition to the Soviet Union, or between the Madonna of $125^{\text {th }}$ Street and

\footnotetext{
${ }^{6}$ For example, see Robin Nagle, Claiming the Virgin: The Broken Promise of Liberation Theology in Brazil and Terry Rey, Our Lady of Class Struggle: The Cult of the Virgin Mary in Haiti.
} 
the struggle of Italian immigrants in New York City, the diverse social and political implications of Mary reveal the fluidity of her symbol (E. Johnson). As Paul Johnson writes, religious images "are never closed symbols. They can always be 'worked'....Constantly making the world appear new, the work of a saint...is never done" (139). The importance of this concept of symbolic flexibility cannot be underestimated in any ethnographic analysis of the Virgin, including my own comparative analysis of La Caridad. For it is the fluidity of La Caridad's symbol that has enabled the diversity of interpretations on both sides of the Florida Straits. It is important to keep in mind that this diversity depends largely on issues of gender, class, and race. Although specific issues surrounding the phenomenon of La Caridad will be analyzed below, here it is incumbent to review the relationship between Marian symbolism and issues of gender, class, and race in general.

\section{Symbolic Liberation}

Whether the Virgin is interpreted as a symbol of oppression or liberation depends on the needs of those who venerate her, needs which are primarily determined by class, race, and gender. When analyzing Cuban devotion to the Virgin of Charity, one must keep in mind these key factors that determine the needs of her devotees. In this sense, it is useful to place Cuban devotion to La Caridad in the larger context of Marian devotion in general.

One of the most contested debates in the study of Mary is the symbolic meaning of her sexual status and how this affects the lives of females who venerate her. While some feminist theologians have found in Mary a positive expression of female power, many interpret the Virgin as a symbol of subordination and oppression (Foskett 2). One 
of the strongest condemnations of the Virgin's myth is Marina Warner's Alone of All Her Sex: The Myth and the Cult of the Virgin Mary, wherein Warner writes that the Virgin myth has condemned women to perpetual inferiority. As "the symbol of the ideal woman," the Virgin encarnates the "feminine" qualities of docility, humility, and submissiveness (Warner 336). This cult of the Virgin's femininity has flourished in countries where women have traditionally been restricted to the domestic domain, such as Spain, Ireland, and Italy (191). Warner maintains that women in these countries do not see Mary as a symbol of hope for a different life, but rather as a model of the ideal submissive housewife (191). This interpretation "both reinforces and justifies the ruling state of affairs," thereby perpetuating the patriarchal myth of female inferiority (191). The acceptance of female submissiveness is thus due to the fact that symbols such as the Virgin "create the inner conditions...that lead people to feel comfortable with or to accept social and political arrangements that correspond to the social system" (Christ 274).

Because symbols have such a compelling effect on the human psyche, feminist theologians argue that their interpretation cannot be left "in the hands of the fathers" (Christ 274). Thus many female theologians have taken the (re)interpretation of the Virgin into their own hands. While some argue that women do not need the Virgin, but rather a goddess who affirms the reality of female power, others embrace Mary herself as a model of liberation, especially female theologians from Latin America. ${ }^{7}$ As Ana María Bidegain writes in "Women and the Theology of Liberation," the figure of Mary "is for

\footnotetext{
${ }^{7}$ On the Virgin of Guadalupe's potential to empower females, see Our Lady of Guadalupe: Faith and Empowerment among Mexican-American Women by Jeannette Rodriguez.
} 
us the power and model of liberation" (31). This interpretation of the Virgin reveals that Marian symbolism is a complex phenomenon, for it transcends issues of female subordination/empowerment and enters the broader sphere of liberation. In the case of La Caridad for Cubans, it is this perspective that is most pertinent. Although issues of gender are clearly significant in the study of Marian devotion, gender is not the most significant factor of Cubans' veneration of La Caridad. For Cubans today, as well as in the past, the Virgin of Charity is not primarily a model of feminine passivity or empowerment. Rather, La Caridad has served Cubans of diverse religious and ideological backgrounds as a model of liberation.

Consequently, La Caridad's role as a liberating force for Cubans on the island should be placed within the larger context of liberation theology. According to Leonardo Boff, a key theme of liberation theology is Mary's role as "the prophetic and liberating woman of the people" (Introducing Liberation Theology 56-7). As an "ally of the oppresssed" (Gebara and Bingemer xi), the Virgin fills the marginalized of society with the strength to struggle for liberation, which for many in Latin America is nothing more than "bread, a roof over their heads, health, peace" (Boff, Introducing Liberation Theology 90). As will be demonstrated in my comparative analysis, these are the primary concerns of Cubans on the island today, whose devotion to La Caridad can be placed in the context of liberation theology. In essence, liberation theology "is about liberation of the oppressed -- in their totality as persons, body and soul -- and in their totality as a class: the poor, the subjected, the discriminated against" (29). Despite contrary claims of the current Cuban government, the political, social, and economic oppression of Cubans 
today cannot be denied. This fact is a significant component of devotion to the Virgin of Charity.

In general, Mary's role in the lives of the impoverished cannot be underestimated. For the poor in Latin America, the Virgin is experienced most intensely at the level of the daily struggle to survive. As Ivone Gebara and Maria Clara Bingemer write in Mary: Mother of God, Mother of the Poor, "life is such a tough battle that the relationship with Mary...is direct: it is connected to the people's immediate and vital needs, since the life of the poor unfolds basically at this level" (126). Throughout Latin America, the impoverished masses bring their troubles to centers of Marian pilgrimage, where "they dry their tears" and "are filled with renewed strength and hope to carry on struggling and surviving" (Boff, Introducing Liberation Theology 58). In this sense, the Virgin is one of the primary ways in which the poor deal with suffering (Espin 55). In the struggle to survive, Mary is "a symbol of the hope that nourishes the poor along their way" (Boff, The Maternal Face of God 162). As will be demonstrated below, the Virgin's role in the daily struggles of Cubans to survive is clearly evident in El Cobre, as is her ability to inspire hope in the future of the island.

In liberation theology, Mary is not interpreted as a symbol of passive hope, but rather as a tool of active liberation. For if she encourages passivity, the Virgin becomes a symbol of oppression by contributing to the status quo. Liberation theology, although primarily centered on the liberating power of Christ, therefore embraces Mary's potential to inspire action in the struggle against all forms of oppression (Boff, The Maternal Face of God 189). For example, the Virgin's potential to inspire political and economic change in Cuba is evident in the decision of the Cuban bishops to release their most 
recent pastoral letter demanding government reform on La Caridad's feast day, examined below. In light of this letter, Boff is correct that Christianity can no longer be dismissed as the "opium of the people," for it has now become "an active component to liberation" (Introducing Liberation Theology 7). Hence Mary can no longer be interpreted as passive; in the words of Pope Paul VI: "Mary of Nazareth...was far from being a passively submissive woman...; she was a woman who had no hesitation in affirming that God is the avenger of the humble and the oppressed, who pulls down the mighty from their thrones. We can recognize in Mary...a strong woman, who knew poverty, suffering, flight, and exile" (Boff, Introducing Liberation Theology 58). Pope John Paul II expresses similar sentiments; he views Mary as a model for those "who do not passively accept the adverse circumstances of personal and social life and are not victims of alienation... but who with her proclaim that God 'raises up the lowly' and, if necessary 'overthrows the powerful from their thrones"' (Gebara and Bingemer 165).

Mary's role as the avenger of the oppressed is rooted in the Magnificat, her prophetic and liberating canticle found in the New Testament, which is fundamental to understanding Marian piety in Latin America (Gebara and Bingemer 165). As Gebara and Bingemer write, "Mary's song is the people's song" (xii), for it sets forth God's "preferential love for the poor" (170). It would be more accurate, perhaps, to say God's preferential love is for the oppressed, a term that includes all marginalized people, including women, racial minorities, and those trapped in poverty.

\footnotetext{
${ }^{8}$ This famous phrase is found in the early writings of Karl Marx, who writes in his "Contribution to the Critique of Hegel's Philosophy of Right" that "religion is the sigh of the oppressed creature....It is the opium of the people" (244).
} 
The ultimate goal of liberation theology, the end of all oppression, is highly unlikely. As long as the conditions of oppression continue to exist, issues of gender, class, and race must therefore feature in any ethnographic anaylsis of Mary's symbolic power. In particular, issues of class and race are crucial to consider when analyzing Cuban devotion to the Virgin of Charity. As such, La Caridad transcends her symbol, for she is a reflection of the social conditions in which she is venerated. Thus the power of any symbol lies in its role as a reflection of society. It is this phenomenon that my theoretical framework will now address.

Symbolic Transcendence

Symbols are powerful forces, for they visually represent what is often difficult to articulate in words. As notes Talcott Parsons, "the essence of a symbol is that its importance, value or meaning is not inherent in the intrinsic properties of the symbol itself, but in the thing symbolized" (Skorupski 118). In general, symbols represent an abstract notion that is often affectively charged, and this affect is transferred to the symbol itself (118). For example, profound feelings of patriotism are transferred to symbols of a country, such as the national flag. Thus symbols reflect a reality or meaning that transcends the symbol itself. As Paul Avis writes in God and the Creative Imagination: "This need not necessarily be a supernatural reality.... The transcendent realm may be the spirit of a nation, a tradition, a cultural legacy, an ethical or political ideal. But it always carries a value greater than the individual" (107).

Religious symbols in particular possess special signifying power. As Mircea Eliade writes in Images and Symbols: Studies in Religious Symbolism, "the symbol, the myth and the image are of the very substance of the spiritual life" (11). Religious 
images, symbols, and myths are a mode of thought and feeling that is an essential function of human consciousness, for they "respond to a need and fulfill a function, that of bringing to light the most hidden modalities of being" (12). Symbols and images are thus necessary to bring to light these hidden modalities that are difficult to articulate. As Eliade writes, images "always express more than the subject who has experienced them could convey in words" (17). Hence religious symbols and images visually convey the ineffable.

Religious images and symbols also possess a communal aspect in the sense that they reflect the community that created and infused them with meaning. Symbols and images are created; in the words of Paul Avis, they are "living, dynamic, the product of creative imagination" (106). As the creation of society, they are cultural products that "articulate the social structures of a believer's world" (Morgan 2). Hence their social function cannot be underestimated. As Robert Cummings Neville writes in The Truth of Broken Symbols, religious symbols "tie a community together with its past, and they also, by virtue of their networked meanings, tie disparate parts and functions of the community into systematic interconnection" (21). Despite the reassuring cohesiveness and uniformity that Neville believes is suggested by symbols and images, a closer examination will often reveal "contradictions and disjunctures that must be mediated or concealed for the sake of a world's endurance" (Morgan 9). Images and symbols may conceal, while not mending, the disjunctures of society, a fact that will be made evident in my analysis of the contested interpretations of La Caridad. Although she may superficially appear to connect all Cubans, a closer examination will reveal the disjunctures of Cuban society inherent in the Caridad cult. 
Although religious symbols may not have the power to mend the fissures of a community, they provide assurance in both the struggles of daily life and the negotiation of significant life changes. As David Morgan writes in Visual Piety: A History and Theory of Popular Religious Images, the power of religious imagery "resides precisely in its contribution to the social construction of reality, whether in the everyday domain of visual and epistemological recipes that guide people through the day or the liminal passages of crisis and transformation that dramatically shape their lives" (17). Thus religious images can be deeply reassuring in both times of normalcy and crisis. Not only do images such as La Caridad enable believers to cope with the reality of exile, but they also enable the preservation of order in times of change. Their ability to preserve order, as illusory as this might be, is due to the fact that the images are reflections of cultural identity that shape the collective memory of a society. In a sense, the veneration of the Virgin of Charity in exile allows Cubans to maintain a sense of order by remaining connected to their collective past. As Tweed writes, devotion of La Caridad enables exiles to be transported to "the Cuba of memory and desire" (10).

Thus when considering the importance of any religious symbol or image, such as La Caridad or any of the various manifestations of the Virgin, one must keep in mind not only the theological implications, but also the social significance. Most importantly, one must realize that every symbol is a reflection of a transcendental realm, whether that be a political ideal, a social tradition, a cultural legacy, or in the case of La Caridad, the fractured spirit of a nation. 
If symbols are indeed reflections of a transcendental realm, then the Virgin of Charity can be analyzed as a reflection of Cuban identity. The following section of my thesis explores various scholarly interpretations of what it means to be Cuban. Identity is a complex issue, and I do not intend to explore its many dimensions, only to present the evolving conceptions of Cuban national identity.

For many years the accepted word to denote "Cubanness" was cubanidad, a word that dates back to the beginning of the nineteenth century (Pérez Firmat, "A Willingness of the Heart" 2). As Fernando Ortiz writes in a 1940 essay entitled Los factores humanos de la cubanidad, this term signifies "the quality of what is Cuban" (149). But what exactly is "Cuban"? Even Ortiz has difficulty in answering this question. To begin with, "Cuba" is not the same concept for everyone. Yes, Cuba is a place, but it is also a people. In addition, there are various ways to be Cuban, such as through birth or residency, but to be born or to live in Cuba does not automatically ensure that one is Cuban. Thus the term cubanidad is not an accurate way to describe Cuban identity because it refers primarily to birth or civil status. As Gustavo Pérez Firmat writes in "A Willingness of the Heart," cubanidad is "generic rather than individual, uniform rather than idiosyncratic. In its narrowest sense, cubanidad designates the junction of nationality and citizenship. As such, it is a civil status embodied in birth certificates, passports and naturalization oaths, and for this reason perhaps the most fragile manifestation of our nationality" (3). For Ortiz, being Cuban requires more than the possession of a Cuban birth certificate or passport; he writes that "the consciousness of being Cuban and the will to want to be Cuban" are also necessary (Ortiz 152). 
Because the term cubanidad does not accurately reflect this will to be Cuban, a key component of Cuban identity, Ortiz coins a term to describe the Cuban spirit: la cubania. According to Ortiz, la cubanía is "a self-conscious, willed cubanidad, a feeling of deep and pervasive identification with things Cuban" (Pérez Firmat, The Cuban Condition 30). Thus while cubanidad is a civil status, cubania is defined by an intense desire to be Cuban. This new term is necessary to distinguish between cubanidad, or "generic Cubanness," and cubanía, or "complete, felt, conscious, and desired Cubanness" (Ortiz 153).

Thus the most important ingredient of the Cuban spirit is the desire to be Cuban. In other words, "Ortiz locates the fullest form of Cubanness in a kind of longing: to desire cubanía is already to possess it" (Pérez Firmat, "A Willingness of the Heart" 7). Because cubania does not depend on place of residence, and therefore cannot be taken away from those who possess the desire to be Cuban, Pérez Firmat believes that it is the expression of Cubanness most available to exiles (8). As he eloquently writes, "I continue to take solace and sanctuary in the Cuba of cubania, a homeland one cannot leave or lose" (11). For Pérez Firmat, cubania is intimate, personal, spiritual, abstract, ineffable, a "willingness of the heart." He writes that (7):

Cubania forms part of one's inner life. It's not asserted but felt, it's not flaunted but desired. It's not a reflex but a choice....Cubanía appears in the theater of the individual's consciousness.... It finds expression not in a nation.... and not in a people...but in something more abstract and ineffable -- in a homeland, una patria.

Although I agree with Pérez Firmat that cubania is a matter of personal desire, its political implications cannot be ignored. In a sense, the construction of the Cuban 
patria has been characterized by elusive desire from the beginning of the nation's history. As Damián Fernández and Madeline Cámara Betancourt write in the introduction to The Elusive Nation, Cuban national identity is "characterized by unsatisfied longing, elusive desire" (3). In the words of Fernández, lo cubano is "the story of desire and disenchantment" (79). From the beginning of Cuban history, Cubans have longed for elusive political goals: sovereignty, democracy, the end of exile (Fernández and Betancourt 3). Over time, "the unfulfilled quest for 'la patria soñada por Martí...increasingly assumed an intense emotional charge.... The desired Cuba has been and is, therefore, an elusive nation caught between ideals and deep dissatisfaction" (Fernández 81). National identity clearly cannot be separated from national politics. In a sense, the politics of cubania are defined by a "chasm between aspiration and realization" (79). This tension between the ideal and the real thus gives cubania a "bittersweet" character. In the eloquent words of Fernández, "bittersweet is the taste of desire and disenchantment and of cubania and lo cubano, time after time" (98).

The bittersweet desire of cubania is clearly evident among Cubans in exile. For many Cubans separated from their patria, the desire to be Cuban is experienced daily in a world of never-ending nostalgia, defined as "the desire to come back to an idealized past" (Belleli and Amatulli 210). Of Greek origin, the word "nostalgia" is formed from the combination of two words: nostos, or "return," and algos, or "grief" (210). Together the Greek words signify "sadness emerging from the desire to go back home" (210). Not only do Cuban exiles desire to return to a mythical homeland of the past, but they also desire to construct a Cuba libre of the future. As long as this dream remains "an 
unrealized project, an unachieved blend of ser and querer ser," this desire can never be completely fulfilled (Pérez Firmat, "A Willingness of the Heart" 8). The unfulfilled desire for a Cuba libre is perhaps one of the most significant reasons why exiled Cubans turn to the Virgin of Charity for psychological comfort. In a sense, she fulfills their desire to be Cuban, at least until the day that their dream becomes reality.

The desire of Cubans to live in an elusive, mythical homeland is not limited to exiles. Those on the island also dream of a future Cuba free from the political and economic restraints of today. Therefore, the unfulfilled desires of Cubans everywhere can be analyzed in terms of elusive liberation. Thus Cubans on both sides of the Florida Straits are united by the bittersweet desire of cubania. As Fernández and Betancourt write, "new generations inside and outside of Cuba, although distanced from one another, are joined by elusive dreams of the nation that should be, not the one that is" (3). Just as exiles pray to the Virgin of Charity for the end of Fidel Castro's government, Cubans on the island pray that their living conditions will improve in the future. This reality is key to understanding the Virgin's role as a symbol of cubania. As long as the desires of Cubans remain unrealized, wherever they live, the Virgin of Charity will thus remain a central aspect of Cuban identity. If and when these desires are realized, the cult of La Caridad will then be transformed from a cult of desire to a cult of gratitude.

The reflections of Ortiz and Pérez Firmat on Cuban identity reflect the fact that identity is dynamic, fluid, and created by the individual. As Jorge Duany writes in "From the Cuban ajiaco to the Cuban-American Hyphen," "for Ortiz, national identity has no essence; it is always in the process of becoming" (13). In a sense, Ortiz was ahead of his time in his emphasis on identity's fluidity. Most contemporary thinking on identity has 
embraced the idea that it is "socially constructed, imagined, and often invented" (Duany, "From the Cuban ajiaco to the Cuban-American Hyphen" 4). The once-prevalent view that national identity is "fixed historically and bounded by geography" has been replaced by the perspective that identity transcends all boundaries (Fernández and Betancourt 2). In this sense, "national identity appears more fluid than static...; its character more elusive and malleable than fixed and permanent" (8). As Stuart Hall writes in "Cultural Identity and Diaspora," identity is a "production" that is never complete (21). Thus it "is a matter of 'becoming' as well as 'being.' It belongs to the future as much as to the past" (23). According to Hall, cultural identities undergo constant transformation due to the fact that identity is fluid, not static.

Not all theorists agree with this position, however, for some possess an essentialist viewpoint on identity, in which nations are concrete and well-defined, culture is homogeneous, and geography is the ultimate determinant of identity (Duany, "From the Cuban ajiaco to the Cuban-American Hyphen" 1). Essentialists thus believe that Cuba is a coherent nation without internal fragmentation, except for the deep rift between those on the island and those in exile (5). In the eyes of many Cubans, the nation and the diaspora are disjointed simply because of the physical separation (Duany, "Reconstructing Cubanness" 18). In a similar sense, Miguel de la Torre writes that "there are two Cubas": the island and the diaspora ("Cubans in Babylon" 73). The conflict between the essentialist and postmodern perspectives on Cuban identity is just one of the many ways in which cubania is contested, a topic I will explore in greater detail later on. Like most scholars, I believe that the essentialist viewpoint is too simplistic to take into account the complexity of Cuban identity. As Duany writes in his essay on 
reconstructing Cubanness, lo cubano should be approached from a deterritorialized, transnational perspective (34).

Because identity is fluid and not restricted by geographical boundaries, la cubania -- like the myth of La Caridad -- cannot be contained within the island of Cuba. To be Cuban one must not necessarily live in Cuba, for the concept of la cubanía transcends the island. To borrow the words of Gloria Anzaldúa, being Cuban is "a state of soul"; it cannot be defined by geographical borders, for it is not a matter of residence, but of spirit and desire. Speaking for Chicanas everywhere, Anzaldúa writes in Borderlands/La Frontera that "deep in our hearts we believe that being Mexican has nothing to do with which country one lives in. Being Mexican is a state of soul -- not one of mind, not one of citizenship" (84). In the same sense, being Cuban is not a matter of living in Cuba, but rather, of the possession of la cubania, Anzaldúa's equivalent to the Mexican state of soul.

Anzaldúa's perspective raises interesting questions about the concept of identity. If being Cuban truly is a state of soul, if la cubania does indeed transcend all boundaries, then theoretically anyone -- regardless of place of birth or residence -- can become Cuban, as long as they possess the desire. Although I have always been Cuban by blood, I have become Cuban in spirit through my academic quest to understand cubania, a quest motivated by my desire to be Cuban. In a sense, I have created my Cuban "state of soul." Yet as affirmed below, not all Cubans share my fluid perspective on identity. In the minds of many Cubans, a girl from Pennsylvania simply cannot be Cuban. In this light, the borders of identity -- despite my personal belief that they can be and often are transcended -- remain in place. 
Based on my self-definition as a Cuban, I agree with Anzaldúa that identity is a state of soul. While I have chosen to express my identity through words, an equally significant means of expression is through the use of symbols. Although many people may feel a deep connection with all things, say, Mexican or Cuban, not everyone can or will express their identity through words. Symbols are often necessary. And so when Mexicans see an image of La Virgen del Guadalupe, or Cubans see an image of La Caridad, they see an expression of their identity - a concept that is difficult to express verbally.

Thus I believe that Portuondo Zúñiga is indeed correct that the Virgin of Charity is a symbol of cubania. She is a visual representation of the "Cuban" spirit, whatever that may mean for the individual. Like Cuban identity itself, the myth of La Caridad is fluid, multidimensional, and complex. Just as the conception of what it means to be Cuban has continuously evolved, so too has the myth of La Caridad, as I will demonstrate in the following section of historical analysis. Yet despite the adaptation of her symbol to meet the needs of various sectors of Cuban society throughout history, two constants have remained among those who venerate La Caridad: the need for liberation and the undeniable desire to be Cuban. 


\section{CHAPTER 4:}

\section{OUR LADY OF CUBA LIBRE}

This chapter of my thesis presents an historical analysis of the Virgin of Charity's political and cultural significance. I analyze how each of the following groups in Cuban society viewed La Caridad as "Our Lady of Cuba libre": the royal slaves of El Cobre, the mambises of the independence wars, the Cuban exile community, and Cubans on the island today. Although each group is unique, their political agendas have all been based on a common goal: the desire for liberty, a goal that is inextricably intertwined with the myth of Cuba's patroness.

The following analysis must first be placed in the context of Cuba's religious history. Although the Catholic figure of La Caridad has indeed become a symbol of national identity, this does not necessarily imply that Cuba is, or ever was, a devoutly Catholic country. As Lisandro Pérez writes in "The Catholic Church in Cuba: A Weak Institution," "the Church never had as profound an impact on Cuba as it had on the rest of the Spanish colonies of the New World" (147). As a social institution, the Catholic Church in Cuba has been historically weak. Unlike the ecclesial hierarchies of most Latin American countries, the Cuban bishops have never possessed significant political power (148). This institutional weakness has been accompanied by a "relative lack of religiosity" in Cuban society, often characterized by its secularism (148).

Pérez attributes Cuba's secularism and the Church's weakness to five factors: the role of Havana as a port city, the organization and operation of the Church in Cuba, the sugar revolution and the secularization of the mill, the importance of non-Catholic religions, and the Church as an enemy of Cuban independence (149-155). The roots of 
Cuba's secularism can be traced to the cosmopolitan character of Havana, a busy port city that contained more than half of the island's population throughout the seventeenth century (150). Havana's "unquestionably secular character" permeated Cuban society, a significant factor of the island's relative lack of Catholic faith (150). A second factor of Cuban secularism is the general dearth of clergy and the concentration of priests in the cities throughout the colonial era and into the twentieth century (150-51). The Church's presence in rural areas, in fact, was "virtually nonexistent" (151). Although the majority of the rural population considered themselves Catholic, the people's relationship with the Church was often limited to baptism (Ramos, Protestantism and Revolution 21).

Also contributing to the weakness of the Church was the sugar revolution, which began in the late eighteenth century and gave rise to a new elite class with secular values (Pérez 151). Furthermore, the sugar revolution dramatically increased the number of African slaves in Cuba, whose religious beliefs gradually fused with Catholic practices. The proliferation of Afrocuban faiths in the nineteenth century is thus another reflection of the Catholic Church's institutional weakness. Although attempts to evangelize the slaves were made, the Church was simply unable to prevent the survival of African religious beliefs. Despite the impact of Afrocuban religions, Pérez writes that a greater threat was posed by the growth of Protestantism during the nineteenth and twentieth centuries (153). Beginning in the late nineteenth century, Protestant missionaries "found fertile ground in Cuba since the rural areas had been traditionally neglected by the Church" (154). ${ }^{9} \quad$ By 1883, the permanent presence of Cuban Protestantism was

\footnotetext{
${ }^{9}$ For a history of Protestantism in Cuba, see Panorama del Protestantismo en Cuba and Protestantism and Revolution in Cuba by Marcos A. Ramos.
} 
established at a time when the anti-independence attitudes of many Spanish bishops turned Cubans away from the Catholic Church (Ramos, Protestantism and Revolution 22). The subsequent growth of the Protestant presence in the twentieth century is yet another factor of the Cuban Catholic Church's historical weakness. By the early 1960s, in fact, the number of Protestants in Cuba reached between 250,000 and 360,000, a significant portion of the island's six million residents at the time (Pérez 154). Thus the historical importance of Protestantism in Cuba clearly cannot be ignored.

A final factor of the Cuban Catholic Church's historical weakness was its "proSpanish" image (Pérez 155). Widely perceived as an enemy of Cuban independence, the Church hierarchy consisted of Spanish priests who understandably supported the continuation of their homeland's rule (155). In the words of John Kirk, "the firm support of the madre patria...can be interpreted as the hallmark of the Catholic Church in Cuba" (5). As a defender of the status quo, Cuba's Catholic Church was viewed as an enemy of the island's rebel fighters during the nineteenth century independence wars. Hatred of Catholicism thus came to be viewed as a political necessity by those who wished to see Cuba free of Spanish domination. As Marcos Antonio Ramos writes, until the creation of the Republic in 1902 "the Cuban Church was nonexistent. The Church was simply Spanish" (Protestantism and Revolution 19-20).

The above brief exploration of the history of religion in Cuba clearly reveals that the island has never been a devoutly Catholic country. According to a 1954 study conducted by a Catholic student organization, 73 percent of Cubans claimed to be Roman Catholics, yet only 24 percent of Catholics regularly attended Mass (Pérez 156). In rural areas, the percentage of Catholics dropped to 52 percent (Kirk 45). Despite their lack of 
regular participation, the survey indicates that most Cubans generally considered themselves to be Catholic in their "own way," an attitude that persists to this day. For many Catholic Cubans, this "own way" involves the cult of La Caridad. Cubans are clearly devoted to the Virgin, but the myth that white Cubans have generally been devout Catholics is simply that -- a myth.

So how did a Catholic virgin become one of the most powerful and enduring national symbols of a relatively secular country? Simply put, La Caridad has always been perceived to be on the side of Cubans, especially during the island's struggles for independence. An additional factor of her immense popularity is her role as a maternal figure who comforts her spiritual children. As my historical analysis demonstrates, the absence of the institutional church in rural areas did not impede the spread of La Caridad's cult, for the veneration of the Virgin requires neither a priest nor a church building.

Furthermore, although veneration of a Catholic virgin may not have theologically appealed to the significant number of Protestants in Cuba, La Caridad did appeal to the Yoruba slaves who appropriated her image as their own. While Cuba's Protestants may not have agreed with the traditional emphasis placed on the Virgin Mary by Catholics, this did not necessarily prevent their admiration of La Caridad as a maternal figure and cultural symbol. Thus despite the island's religious heterogeneity, the Catholic Church's institutional weakness, and Cuban society's secular character, the Virgin of Charity has served as the spiritual mother of Cubans for more than four centuries. It is to the Virgin's historical evolution that my analysis now turns. 
The veneration of the Virgin Mary in Latin America and the Caribbean can be traced back to the arrival of the Spaniards in the fifteenth century. ${ }^{10}$ Due to the process of evangelization, the natives in Cuba were taught to venerate Mary long before la Virgen de la Caridad was revered (Portuondo Zúñiga 69). Since the discovery of this particular statue in 1612, the myth of La Virgen in Cuba has evolved to adapt to changing conceptions of identity and the patria. In order to understand this evolution, an examination of the myth's historical origins is first necessary.

Due to the Spanish crown's desire to extract copper in Cuba, the mining center of Santiago del Prado (also known as El Cobre) was founded by Spain in 1599 (Portuondo Zúñiga 81). It is in this important commercial center that the myth of La Virgen de la Caridad was born and originally cultivated. By 1608 the mining village consisted of 215 African and Creole slaves, one of whom, Juan Moreno, went on to play a crucial role in the consolidation of the myth (84). In approximately 1612, Moreno accompanied two Indian brothers named Rodrigo and Diego Hoyos in a small boat to collect salt in the Bay of Nipe, where they encountered the statue of La Virgen floating on the sea (Marrero, Cuba: economia $y$ sociedad 92). On the base of the statue was the following inscription: Yo soy la Virgen de la Caridad. The Indians then transported the statue to Santiago del Prado, where it was eventually placed in its own shrine (Portuondo Zúñiga 94). Although the natives' influence in the development of La Caridad's cult is not a focus of my historical analysis, her syncretic relationship with Atabey, the Taíno goddess of lakes and

\footnotetext{
${ }^{10}$ See "The Evolution of Marian Devotionalism" by Anthony Stevens-Arroyo for information regarding the development of the Virgin's cult in Spain.
} 
rivers, is an important element of the myth's origins. As Antonio Benítez-Rojo emphasizes in his interpretation of the myth, the Virgin of Charity was initially adored by native Cubans as both Atabey and Caridad (14). This complex relationship between the Taíno goddess and the Catholic virgin is often ignored by scholars, but it clearly deserves more attention. ${ }^{11}$

Soon after the statue's discovery, devotees of La Virgen began to report miracles associated with her presence in the community, miracles which thus sealed the myth's survival among subsequent generations (Marrero, Cuba: economía y sociedad 92). Through oral tradition, stories of La Caridad's discovery were passed from generation to generation. Therefore, Moreno's version of the Virgin's apparition represents only one account. Subsequent versions of her appearance do not mention the Hoyos brothers. Rather, many Cubans today believe that the Virgin appeared to three fishermen, two whites and one black, and calmed the waters during a fierce storm (Arrom 211). In yet other versions, the men were all black or all white, due to changing conceptions of Cuban identity through the centuries. However one chooses to identify the men, the changing racial identities of the Virgin's discoverers clearly reveal the fluidity of her myth, a characteristic that will be made evident in the following historical analysis of her symbolic appropriation.

Most Cubans today associate the story of La Virgen with the Tres Juanes: Juan el Blanco, Juan el Negro, and Juan el Mulato (Portuondo Zúñiga 33). The Three Juans are often associated with the three principal ethnic elements of Cuban identity: African,

\footnotetext{
${ }^{11}$ For information on the influence of native Cubans in the development of La Caridad's cult, see María del Pilar Poviones-Bishop, "The Braids of the Virgin: Taíno Roots of the Early Cult of La Virgen de la Caridad del Cobre in Cuba." M.A. Thesis, Florida International University, 2002.
} 
European, and Native American. As Arrom writes, "the three Juans are singular and triune because essentially our culture is singular and triune...In the canoe is the marvelous essence of our nationality" (214). Thus oral tradition associates the three Juans with a mythological utopia of ethnic harmony. In the words of Benitez-Rojo, the idea "conveys mythologically the desire to reach a sphere of effective equality where the racial, social, and cultural differences that conquest, colonization, and slavery created could coexist without violence" (52). As my thesis will reveal, the Cuban desire for equality remains unrealized to this day, for both La Caridad and Cuban identity remain contested notions. For now, however, I will focus on the Virgin's historical potential to unify certain sectors of Cuban society.

The Royal Slaves and the Virgin

As mentioned previously, the Virgin Mary has often been associated with liberation movements throughout Latin America and the Caribbean. Most notable is Mexico's Hidalgo Revolt of 1810 , inspired by devotion to the country's patroness, the Virgin of Guadalupe. Thus the association of Cuba's patroness with its various liberation movements is not unique. What is unique, however, is the community of El Cobre itself. The negotiation of freedom by the royal slaves of El Cobre in the eighteenth century, and the role of La Virgen in their quest for liberty, is a story often ignored by both modern Cuban devotees and scholars. In the words of María Elena Díaz, the cobreros are a "people without history," due to the lack of academic attention (6). Their story, however, exemplifies both the community's spirit of freedom and the power of the Virgin's myth as a tool of political unity. When considering the implications of this community's struggle for freedom, one must keep in mind that this was not a struggle for a Cuba libre, 
but rather, for a Cobre libre. The idea of Cuba as a nation did not yet exist; therefore, conceptions of the patria were limited to the patria chica, the local community.

The story of the royal slaves begins in 1670 when Spain confiscated the mines of El Cobre from a private contractor (Díaz 9). Suddenly, the 271 slaves of the mines were now slaves of the king. For the next one hundred years, however, the community was virtually free from government control; in fact, the government bothered the slaves only to count them or to demand service in the militia (Marrero, Los esclavos y la Virgen del Cobre 25). In the words of Leví Marrero, the royal slaves "began to live as free people" due to the lack of governmental control (24). Díaz echoes the conclusion of Marrero in her study of El Cobre, in which she argues that the royal slaves reconstituted themselves into a pueblo (10). She writes that "life in and as a pueblo entailed important reformulations of the meaning of slavery that pushed its limits into the realm of freedom" (11). As a pueblo, the slaves thus began to identify themselves as cobreros and developed a sense of patria chica. An appreciation of this sense of unity is crucial in order to understand the political mobilization of the community in the eighteenth century. This mobilization enabled the community to negotiate such rights as the right to mine and market copper, to own property, and to have a legal spokesman (Díaz 320). These entitlements are truly extraordinary when one considers that El Cobre was technically a slave society.

The cobreros' desire for freedom was the underlying motivation for their political agenda. The first act of communal mobilization in which the community clashed with the government occurred in 1677 , when male slaves received royal orders to move to Havana in order to work on military fortifications (Díaz 74). In response to these orders, 
Juan Moreno, the same slave who witnessed the Virgin's appearance, wrote a collective petition that expressed the slaves' reluctance to move. On July 13, 1677 Moreno wrote that "the love for our patria and our work moves us to ask...the mercy of being allowed to stay in our pueblo, paying tribute, in whatever manner it is arranged for us while we find a way to pay for our freedom" (Díaz 74). This petition represents a significant political act in the context of slavery, the first of many ways in which the slaves of El Cobre would negotiate their freedom in the next century. Although the petition received no response, the flight of several slaves into the surrounding mountains caused a local judge to decree that the slaves could not be sent to Havana (Díaz 92). In the words of Díaz, this victory is just one example of the "ambiguous ways of living between slavery and freedom" that characterized the community of El Cobre at this time (94).

The consolidation of the pueblo coincided with the expansion of the cult of $\mathrm{La}$ Virgen de la Caridad. This expansion is largely due to the central role played by the royal slaves, who claimed the Virgin as their patroness and protectress (Díaz 95). Juan Moreno's 1687 account of her apparition not only contributed to the expansion of the cult, but also served to legitimize the political aspirations of the community. In the words of Díaz, Moreno's story "became a major discursive site for the articulation of the community's identity and for many of its political aspirations" (96). Due to the Virgin's identity as the protectress of the mines, the cobreros began to self-identify as her chosen people, an identity which encouraged them to believe in their rights and unified the community in its political struggles. This unity was the source of the community's strength; in the words of Portuondo Zúñiga, "they found strength in unity, and the Sanctuary was the symbol of the community's sacred union" (158). 
The political struggles of the cobreros were in a sense legitimized through the divine favor of the Virgin. According to Moreno's account, she had chosen the site of her shrine, and consequently, the cobreros believed that she had thereby chosen to protect the community of El Cobre itself. Therefore, they felt entitled to the land on which they lived and worked, despite the fact that they were royal slaves. Their desire for autonomy is clearly evident in their refusal to participate in a 1731 military parade in Santiago, an act of protest against the abuse of their rights by the government (Portuondo Zúñiga 152). Instead of marching, many of the cobreros fled to the mountains. Before fleeing, however, they attempted to remove the image of La Caridad from her shrine. Although they were unsuccessful, this action demonstrates that they believed the Virgin was indeed theirs. Their revolt was condemned by the governor of Cuba at that time, Pedro Ignacio Ximénez, who denounced the slaves for "their corrupt inclination, desiring to live in complete liberty" (Marrero, Los esclavos y la Virgen del Cobre 26). After discovering the directors of the 1731 plan, Ximénez exiled 36 of the slaves, who became "the first Cubans forced into exile" (27). In 1733, however, the king defended the cobreros in a royal decree in which he ordered that they be treated without oppression (Portuondo Zúñiga 153). In gratitude, the miners gave thanks to the Virgin because she had permitted them to be heard by the king (153).

Although the royal slaves did enjoy certain entitlements due to their association with the king, tension existed between the cobreros and the local government officials. The slaves' special privileges, however, came to an end in 1780 when the mines of El Cobre were reprivatized (Díaz 180). In reaction to this royal edict, the cobreros wrote a 1783 document in which they protested their loss of rights by relying heavily on their 
privileged association with La Caridad (105). The document includes several examples of her power to intervene and prevent the community's loss of freedom. For example, it implies that the Virgin had the power to spur political support for the cobreros among certain sectors of colonial society. This is evident in the story of Governor de Céspedes' daughter, who fell ill and was then cured by the mantle of La Caridad. Out of gratitude to the Virgin, the governor did not immediately proceed with the 1780 royal orders to hand over the natives of El Cobre to the new private owners of the mines (Díaz 108). This story exemplifies the political potential of the myth and its power to give legitimacy to the community's claims; in the words of Díaz, "both the story and its political uses illustrate, how, by virtue of the cobreros' association with the Marian cult, their claims to community have been legitimized in the eyes of many believers" (109).

Despite the reprivatization orders of 1780 , the royal slaves of El Cobre remained convinced that they were not slaves. For the next twenty years, their struggle to achieve total freedom continued through such acts of political mobilization as flight, violence, and litigation (Díaz 324). Faith in the Virgin played a prominent part in their argument, and also helped to keep the community united. The cobreros' political negotiations culminated in the request for collective freedom, which was finally granted in a royal edict signed on April 7, 1800 and appropriately read from the steps of the Virgin's shrine. Even after formal freedom was granted, however, restrictions remained because the community was still subject to forced labor obligations (Díaz 320). Regardless of these restrictions, the achievements of the cobreros are truly extraordinary in the context of slavery. Although La Virgen de la Caridad may not have been a necessary factor of these achievements, her power as a tool of unity in the shaping of identity and the struggle for 
freedom cannot be denied. While La Caridad may not have been a symbol of cubanía for the cobreros (due to the fact that the concept of Cuban identity had not yet developed), she certainly symbolized the unique identity of the town of El Cobre.

Despite the Virgin's popularity today among Cubans, few remember the local context in which her cult emerged. In the words of Díaz, "there is...little memory among Cubans today of the remarkable historical community in which the Virgin of Charity's legend and tradition first flourished" (329). Although the origins of the cult may be forgotten today, it is crucial to remember that devotion to La Caridad first developed among this unique community before spreading throughout $\mathrm{Cuba}$ in the following century. As Antonio De Herrera-Vaillant writes in his essay about El Cobre, "the devotion of the humble royal slaves of Santiago del Prado became the devotion of an entire nation and its army" (25). It is this national army that my analysis now addresses.

\section{La Virgen Mambisa}

The belief in La Virgen gained prestige in the nineteenth century due to the legend of the struggles of the cobreros. As more pilgrims continued to visit the shrine in El Cobre, the cult slowly spread throughout Cuba. At the same time, thoughts of liberty also increased, and the desire for a Cuba libre began to intensify. Consequently, as criolles throughout Cuba assumed belief in the Virgin, she now "incarnated the utopia of freedom" (Portuondo Zúñiga 203). No longer merely a symbol of El Cobre, La Caridad now symbolized the dream of a free Cuba.

The desire for a Cuba free from the control of Spain ultimately led to la Guerra de los Diez Años in 1868, the first Cuban war of independence. According to Portuondo Zúñiga, La Virgen played a crucial role in this first armed struggle for freedom because 
she "served as a catalyst for unity among all Cubans" (226). Once again, as in El Cobre, Cubans appropriated the Virgin as a political tool of unity in order to achieve the elusive goal of liberty. It is important to keep in mind, however, that the Catholic Church hierarchy in Cuba did not share this popular view of the Virgin, due largely to its continued support of Spain. In spite of the lack of church support, the revolutionaries immediately began to appropriate La Virgen as the symbol of their cause. In fact, she now became known as La Virgen Mambisa, in reference to the mambises, the Cuban rebels (Portuondo Zúñiga 226). Her association with the Cuban desire for liberty is reflected in the following copla sung on the battlefields during the first independence war (229):

\author{
Virgen de la Caridad, \\ Patrona de los cubanos, \\ Con el machete en la mano \\ Pedimos la libertad. \\ (Virgin of Charity, \\ Patroness of Cubans, \\ With machete in hand, \\ We ask for liberty.)
}

The potential of the Virgin to serve as a tool of unity among Cubans is evident in the actions of Carlos Manuel de Céspedes, the Padre de la Patria and leader of the independence movement who in 1868 visited her sanctuary with his mambises (Portuondo Zúñiga 226). At the shrine Céspedes and his troops gave a patriotic tribute to the Virgin, an act of devotion that clearly was more than sacred. As Portuondo Zúñiga writes, "it was a political gesture of the Father of the Homeland that recognized devotion of the Virgin as a powerful means of union among Cubans" (226). As mentioned previously, the Virgin's identification with Cuba's liberation movement is similar to the 
role played by La Virgen de Guadalupe in Mexico's struggle for liberty. Both instances reveal the unifying power of religious symbols in political quests.

Although the first war of independence did not result in a Cuba libre, principles of patriotism remained united to the cult of La Virgen for the next several decades, until the second, and final, war of independence broke out in 1895. In this war, the mambises continued to associate the Virgin with their cause; members of the Liberation Army often carried medals of their protectress into combat, including such leaders of the war as Antonio Maceo (Portuondo Zúñiga 230). Wives and mothers of the mambises also frequently prayed novenas to La Virgen to protect their husbands and sons on the battlefields (231). By the time that Cuba finally achieved independence from Spain in 1898, the Virgin of Charity "had become the rebel Virgin, the patriot Virgin, the national Virgin" (Tweed 23). In the same sense that she enabled the royal slaves of El Cobre to articulate their identity, she now enabled Cubans from across the island, of all races and classes, to affirm their status as an independent nation. No longer merely a symbol of El Cobre, La Caridad had become a symbol of cubania, a reflection of the desire of the island to achieve independence. Thus the power of the Virgin's ability to unify is evident in the coming together of diverse sectors, whose bonds were based on a common belief in the national mother.

The actions of General Calixto Garcia, the chief of the Cuban army in Oriente, clearly demonstrate the importance of the Virgin's role in the war. In gratitude for her help in securing the independence of the island, García and his troops celebrated a Mass at the Virgin's shrine on September 8, 1898 (Román 1). At this Mass the mambises recognized that she had accompanied them throughout the most difficult moments of 
battle. This gesture of thanksgiving has been called la Declaración Mambisa de la Independencia del Pueblo Cubano (Román 1). Despite the achievement of independence, however, fears of the continued American presence and the possibility of annexation in Cuba abounded. Therefore, the Cuban priest who celebrated the Mass attempted to assuage the fears of the mambises by appealing to the Virgin, who he believed would assure the consolidation of the republic (Portuondo Zúñiga 231).

At the turn of the century, La Virgen de la Caridad was thus inseparable from the national identity of Cuba. This led to a growing desire among Cubans to declare her the official patroness of the island, a movement which was appropriately led by the veterans of the independence wars. In 1915, a group of 2000 mambises traveled to El Cobre for a reunion in which they once again expressed their gratitude for La Caridad's role in the war (Tweed 23). More importantly, they wrote a letter to the Vatican requesting that the Virgin of Charity be declared the official patroness of Cuba. In the words of the mambises addressed to Pope Benedict XV, "as members of the Liberating Army of Cuba, we turn to Your Excellency to realize the most beautiful of our hopes and the most noble of the aspirations of the Cuban soul: to declare the Virgin of Charity Patroness of our young republic" (Rabí et al 1). The soldiers go on to write that the Virgin was a guiding light of consolation during the war. In their minds she was "an excellent Cuban" and therefore, deserved to be declared the patroness of the island, a title made official on May 10, 1916 by the Pope (Portuondo Zúñiga 245). Thus the regional protectress of El Cobre had now officially become the national patroness of Cuba.

Over the next few decades, as Cuba experienced the difficulties of the consolidation of the Republic, devotion to La Virgen continued among all sectors of 
Cuban society. However, now that political freedom had been obtained (at least in name), she was no longer politicized or appropriated as a tool of unity. The events of 1959 , however, would once again bring the Virgin to the frontlines of the political battlefields.

¡Virgen de la Caridad, salva a Cuba!

Like the mambises of the independence wars, members of Fidel Castro's Rebel Army often carried medals of the Virgin of Charity (Portuondo Zúñiga 271). In gratitude for the success of the rebels' campaign in 1959, many pilgrims came to the Virgin's sanctuary to give thanks for the fall of the dictator Fulgencio Batista (271). After the euphoria of the revolution, however, social tension among many of La Caridad's devotees became apparent. In November 1959, Catholic authorities organized a visit of her original image to Havana for the National Catholic Congress, one of the most significant events in the history of the Virgin (Tweed 24). This religious reunion became a political protest, an act of defiance that revealed the growing disillusion among many Cuban Catholics with Castro. To the same rhythm of iParedón! cried by Castro's revolutionaries, the anti-Castro Catholics at this reunion began to chant ;Caridad!, a clear indication that not only did they reject Castro, but that they also claimed the Virgin for their side (Tweed 24). Just as in the independence wars, Cuba's patroness was once again associated with political protest. The politizication of La Caridad's symbol clearly reveals that the political dimensions of cubania cannot be ignored.

Tensions between Catholics and Castro were just beginning. Many counterrevolutionaries appropriated the Virgin as a symbol of their cause, a motherly figure who would protect them in their quest for a Cuba libre. In this context, a Cuba libre signified 
a Cuba without Castro, as opposed to the Cuba libre of the mambises, which signified a Cuba without Spain. The hopes of the counter-revolutionaries were dashed, however, when the Bay of Pigs invasion failed in April 1961. Had they been successful, the exile brigade who led the invasion would have read a proclamation in which they claimed the Virgin for their cause: "Have faith, since the victory is ours, because God is with us and the Virgin of Charity cannot abandon her children" (Tweed 25). Tensions between Catholics and the Cuban government intensified as the Virgin's feast day of September 8 approached. Despite the cancellation of the annual procession in Havana, due to the government's declaration that it could only be held at 7:00 a.m., about 4,000 devotees gathered in front of the Parish of La Virgen de la Caridad in Havana on September 10, 1961 (Tweed 25). They started to process through the streets, toward the presidential palace, and gradually the religious procession became a political protest. This act culminated in a shootout with the police that resulted in the death of a young man who had led the protest, and caused the government to prohibit all subsequent religious processions (26).

Events such as this led many Cubans who opposed the revolution into exile. Most believed that the Virgin was on their side. As Thomas Tweed writes in Our Lady of the Exile, exiled Cubans "felt sure about where the Virgin stood on the issue: she stood with them, opposing Castro and socialism and advocating democracy and capitalism" (26). Once again, the Virgin of Charity had become a tool of political unity in the struggle for a Cuba libre. In exile, she became a powerful symbol of the dream of Cuban exiles around the world: a Cuba libre. Nowhere is this dream more tangible than in Miami, the center of the Cuban diaspora. Although Portuondo Zúñiga devotes only three paragraphs to the 
evolution of the Virgin's myth in exile, I believe it is a crucial aspect in any analysis of the role of Cuba's patroness. For her role in exile not only shows the power of the Virgin among Cubans as a tool of political unity, but also demonstrates the fluidity of the myth in its various appropriations as a symbol of a Cuba libre.

The Virgin's power is clearly evident in the events of September 8, 1961 in Miami, two days before the violence erupted in Havana. Many Cubans had already chosen to leave the island and began to plan their own celebration of the Virgin's feast day. Through the help of Italy's ambassador to Cuba, a replica of La Virgen was smuggled from a church in Havana to Miami Stadium on September 8, just in time for the celebration which drew over 25,000 Cubans (Underwood 1A). As she entered the stadium, the crowd began to weep and shout and sing, full of the emotions of exile, overcome with joy that a piece of their homeland had been recovered. This was clearly more than a sacred celebration, however; it also gave the exiles an opportunity to pray collectively for the fall of Castro. As John Underwood wrote in "Exiles Pray for End of Tyranny," a front page article in The Miami Herald the following day, "it was...the first time exiled Cubans of all political leanings were thus united and was easily the largest show of allegiance since the abortive April invasion" (1A). Thus the Virgin of Charity once again united Cubans in their struggle to achieve the elusive goal of liberty. Cuban devotion to the Virgin in Miami soon became so intense that the Archdiocese of Miami decided to construct a shrine, the Ermita de la Caridad, in 1967 (Tweed 99). Six years later, over 10,000 Cubans gathered in 1973 to dedicate the shrine, waving Cuban flags and shouting Virgen de la Caridad, jdevuélvenos a Cuba! (100). 
Thus from the beginning, the Virgin's shrine in Miami has assumed a political significance. In order to fully appreciate this political significance of La Caridad in exile, one must first understand the demography of Cubans in Miami. Important factors to consider when analyzing the shrine, and the evolution of the Virgin's myth in general, are the race, class, religion, and generation of the devotees who visit. According to Tweed, most of the devotees who visit the shrine, both then and now, are white, middle-class, Catholic Cubans (64). Before 1959, however, the devotees who visited the Virgin's shrine in El Cobre were disproportionately lower-class blacks, many of whom practiced Afro Cuban religions (64). This difference in demographics is obviously due to the disproportionate number of white, middle-class, Catholic Cubans who went into exile in the early 1960 s, part of the first wave of exiles that brought about 200,000 Cubans to the United States (Grenier and Pérez 23). Members of the upper classes, many of these "golden" exiles were skilled professionals who today consider themselves "the principal standard-bearers in the sustained struggle against the Cuban government, the faithful keepers of the exile legacy" (23).

The second wave of exiles brought another 260,000 Cubans to the United States between 1965 and 1973 (Grenier and Pérez 24). The next major exodus occurred in 1980, during the Mariel boatlift that brought over 125,000 Cubans to the United States. For the first time, Afro Cubans and members of the lower classes constituted a large percentage of the immigrants (Grenier and Pérez 24). Following the influx of the marielitos, the next wave of Cuban immigrants consisted of the balseros, thousands of whom left the island by raft in the early 1990s (25). Unlike the "golden" exiles, most of whom fled Cuba for political reasons, the majority of marielitos and balseros left Cuba 
because of economics. During the rest of the decade, about 20,000 Cubans continued to immigrate annually to the United States by legal means, although illegal migrations persisted (Grenier and Pérez 26). According to the 2000 census, over 1.2 million people of Cuban "origin or descent" live in the United States today, 65 percent of whom live in Southern Florida (26). While 700,000 Cubans in the United States are considered firstgeneration exiles because they were born on the island, a significant percentage was born in the United States. Thus in addition to immigration wave, another crucial factor to consider in the demography of Cuban Miami is place of birth.

As the above exploration of exile demographics reveals, differences in race, class, religion, immigration wave, and generation are crucial factors in the veneration of $\mathrm{La}$ Caridad in exile. These differences will be explored in greater detail below in my comparative analysis of the Virgin's current significance. Clearly the different religious, social, and political backgrounds of the "golden" exiles, marielitos, and balseros must be taken into consideration. While members of the first wave are more likely to be white, middle-class Catholics, members of subsequent waves are more likely to be workingclass Afro Cubans who blend African and Catholic religious beliefs. Thus although La Caridad is widely perceived as the spiritual mother of all Cubans, a closer examination of these demographic differences will reveal that Cuban identity is indeed a contested notion.

Despite these critical differences, for most Cubans in exile La Caridad remains the symbol of their collective dream: a Cuba libre. Therefore, the evolution of the Virgin's myth of exile has led to the intensification of her nationalistic significance (Tweed 63). Through devotion to the Virgin, Cubans in exile retain the hope that one 
day Cuba will be free. In the words of a white, middle-class Cuban male who often visits the shrine in Miami, his devotion to the Virgin is important because "it is that which maintains my hope to see my country free" (78). According to Tweed, the overwhelming majority of Cubans who visit the shrine pray for the liberation of Cuba from Communism. This desire is incarnated in the symbol of La Caridad, whom Cubans view not only as the mother of Christ, but also as the mother of their imagined nation, the Cuba libre of their dreams. In this sense, she is a symbol of longing, a reflection of elusive liberty.

Furthermore, La Caridad is a symbol of cubania, the desire of exiles to remain Cuban despite the physical separation from their homeland. By remaining devoted to the Virgin, exiles are able to maintain a collective link to their past. As Tweed observes, the use of common symbols like La Caridad enables exiles to retain bonds with the homeland, a crucial aspect of the construction of diasporic identity (84). He correctly believes that a central element of the exilic construction of identity is "diasporic religion," which "negotiates diasporic identity as followers remember the homeland's past and imagine its future" (86). In a sense, Cuban exiles have turned to religion, and to the Virgin of Charity in particular, to make sense of the disorientation of exile. In the words of Eduardo Boza Masvidal, the Virgin in exile is "a link of national unity in the permanent and fundamental values which we share" (202). Although most exiles tend to believe that such links of national unity enable them to "reaffirm" their identity, Tweed emphasizes that diasporic identity is dynamic and constantly reconstructed as symbols like the Virgin acquire new significance (85). 
The most important celebration of the Cuban diasporic religion is the annual feast day celebration on September 8, in which La Caridad's role as the symbol of Cuba libre is central. In the words of one 57 year-old woman who attended the celebration in 1991, the festival is so important because "for me it is a way of celebrating the Virgin's day united with all to ask for the liberty of Cuba" (Tweed 126). At that celebration in 1991, the fall of Communism in Eastern Europe stirred hope among the community that a transition to democracy in Cuba was right around the corner (132). From the altar, the priests predicted that next year Christmas would be celebrated in Havana. Two years later, even though they still celebrated Christmas in Miami, many exiles believed that their dream of a Cuba libre was about to be realized once again. At the 1993 celebration, they arranged flowers to say Libre '94 above the image of the Virgin, a reflection of the community's hopes that Cuba would be liberated from Communism the following year (Tweed 116). As usual, their hope remained illusory, yet the exiles continue to pray unabated to the Virgin to "save Cuba." Since 1961, for example, Father Pedro Luis Pérez has led the recital of the rosary at every celebration in a uniquely Cuban way: he interrupts the prayers to shout !Virgen de la Caridad!, to which the crowd responds, Isalva a Cuba! (Tweed 128).

In addition to symbolizing the exile community's dreams, La Caridad also symbolizes their collective past, especially the historical struggles for liberty. Participating in the annual celebration thus returns the Cuban exiles to this shared history. This is clearly evident when the statue of the Virgin enters the site of celebration and the crowd sings La Virgen Mambisa: Todos tus hijos a ti clamamos, Virgen Mambisa, que seamos hermanos ("All your children cry to you, Virgen Mambisa, that we become 
brothers") (Tweed 130). In the words of Tweed, "to sing La Virgen Mambisa as the statue enters is to align oneself ritually with los mambises" (132). Furthermore, although they may not realize it, the exiles also align themselves with the royal slaves of El Cobre, due to not only the common devotion to the Virgin of Charity, but also to the shared sense of the value of liberty. Although the Virgin's myth may have been transformed to serve the needs of these various sectors in Cuban history, essentially their political agenda remained the same: libertad.

Reina de la República

Although devotion may not have been as intense in Cuba during the past four decades as it has been in exile, the Virgin continues to be venerated on the island. Historically the Cuban Catholic Church has been a relatively weak institution, yet popular belief in the Virgin Mary has always remained strong. Despite the religious restrictions imposed by the revolution after 1959, many Cubans on the island have maintained faith in the Virgin of Charity. Although public expressions of their faith were severely restricted for decades, La Caridad's sanctuary in El Cobre never closed. The shrine was seldom visited, however, due to the climate of fear imposed by the Cuban government. In the words of one volunteer at the shrine: "the shrine never closed after the revolution, but many people were afraid to come. Those were years of repression -we were not allowed to publicly express our faith for many years. I was never afraid -- I was still able to study and become a nurse, but the climate of fear was prevalent."12

\footnotetext{
${ }^{12}$ Personal interview with shrine volunteer (December 10, 2003)
} 
After the Cuban government abandoned its official policy of atheism in the early 1990s, La Caridad's shrine began to recover the popularity it had lost during the previous three decades. On September 8, 1993, her symbol was once again appropriated to advance demands for Cuban liberty. On that day the Cuban bishops released a pastoral letter entitled El amor todo lo espera. Their decision to publicize this letter on La Caridad's feast day clearly reveals the power of her symbol. Written in the midst of the "Special Period," a time of intense economic crisis, the letter condemns the excessive control of the government and "the exclusive and omnipresent character of the official ideology." Specifically, the bishops requested an end to the discrimination against and the imprisonment of Cubans whose political and/or religious creeds conflict with the official government ideology. For the first time in years, the bishops of the island made their voice heard, condemning the "grave circumstances" that had led to the "Special Period." In their own words, "in the present grave circumstances it seems that if there are no real changes, not only economic, but also political and social, our achievements could be crushed after years of sacrifices." Simply put, the "Special Period" was a time of crisis. Thus the intensified devotion to the Virgin of Charity is not surprising, for the role of a nation's patron saint has always strengthened during times of political crisis. As Rey writes, "the more the crisis worsens, the deeper the people's fervor in prayer to the Virgin for their liberation" ("The Politics of Patron Sainthood" 538).

During the 1990s, the Cuban bishops' demand for increased religious freedom was partially met. The government relaxed its stance on religion, and gradually people began to publicly display their faith in greater numbers. On September 8, 1996, an unprecedented crowd of thousands made a procession to La Caridad's shrine in El Cobre 
(Díaz, "Rethinking Tradition" 47). The increased acceptability of public expressions of faith is evident in the government's decision to allow the 1998 Papal visit, during which Pope John Paul II declared the Virgin to be la Reina de la República (Mensajero de la paz y la esperanza 52). According to Díaz, La Caridad's coronation "reactivated the icon as an emblem of the Cuban nation, a symbol of cubania" ("Rethinking Tradition" 47). In addition, the coronation effected new relations between the church, the state, and the Cuban people. Although the Virgin's role as a symbol of Cuban identity may have been suppressed by the revolution for decades, she had now become the Queen of the island.

Once again, here the symbol of La Caridad was appropriated as a means to unify Cubans in their quest for political, economic, and social liberty. The crowning of the Virgin occurred during the pope's Mass in Santiago de Cuba, held in the Plaza Antonio Maceo, a powerful reminder of the Virgin's connection with the mambises. The Pope centrally featured the historical significance of the Virgin in his homily, in which he mentioned the connections between Cuba's patroness, the slaves of El Cobre, and such independence leaders as Céspedes, Maceo, and Calixto García, all of whom chose "the path of liberty" (Mensajero de la paz y la esperanza 53).

Liberty was a central theme of the Pope's homily, not only liberty of the Catholic Church, but also of each individual on the island. In his words, faith is necessary to achieve "true liberty, which includes the recognition of human rights and social justice" (Mensajero de la paz y la esperanza 54). In order for the Cuban desire for liberty to be fulfilled, the Pope recognized that unity was essential, and so he called on the Virgin "to unify, and reconcile, all Cubans as a national community over and above ideological differences in the present" (Díaz, "Rethinking Tradition" 47). In other words, the Virgin 
possesses the potential not only to unify Cubans on the island, but also to reunite exiles "by means of reconciliation and fraternity" (Mensajero de la paz y la esperanza 56). As Díaz writes, this is "a demanding feat that may take a veritable miracle from the virgin mother of all Cubans" ("Rethinking Tradition" 47).

Although the Virgin may have had the power in the past to unify politically the cobreros, the mambises, and the exiles, does she have the power to heal the wounds of a divided nation? The events surrounding the return of the young balsero Elián González to Cuba in 2000 suggest that reconciliation is not as attainable as the Pope suggests. On both sides of the Florida Straits, Cubans appealed to La Caridad to protect the boy from either the "Miami mafia" or the "evils of Communism." Once again, the Virgin in the Elián saga was politicized, as devotees in both Miami and Cuba claimed that La Caridad was on their particular side. ${ }^{13}$ While exiles went to Caridad's ermita to pray that Elián could remain in the United States, Cubans on the island journeyed to El Cobre to implore Caridad to bring the boy home. As one of the volunteers at the El Cobre sanctuary told me:

Elián's father came here two months before his return, in April of 2000. He went up to the Virgin crying.... He didn't know what to ask for. "Just ask for your son," we told him. He did, and two months later, the boy was returned. ${ }^{14}$

The passionate intensity of Cubans in both Miami and Cuba during the Elián affair clearly reveals that the challenges of reconciliation will not be overcome merely through a common belief in the Mother of Cubans.

\footnotetext{
${ }^{13}$ See Ikam Acosta, "Boy Exile Turned Saint: Elián González as a Contested Religio-ideological Symbol among Cuban-American Catholics." M.A. Thesis, Florida International University, 2001.

${ }^{14}$ Personal Interview (December 10, 2003)
} 
As the above historical analysis demonstrates, for four centuries various sectors of Cuban society have appropriated, contested, and reinvented the myth of La Caridad to meet their own needs in the never-ending quest for liberty. Based on the Virgin's historical ability to unify Cubans, Cubans in both Miami and Cuba continue to believe that the Virgin of Charity has the ability to unify all her children in "one indivisible nation" (Cutié 3). When one considers the complex and contested nature of Cuban identity, however, this belief is revealed to be idealistic. As María Elena Díaz writes in "Rethinking Tradition and Identity," the fact that La Caridad is an icon of cubanía does not signify "that there is, or has been, just one formulation of the Cuban nation. Nor for that matter has the virgin been a univocal symbol of cubania throughout modern years" (43). In the words of Fernández and Betancourt, "what today is recognized as a pillar of the collective sense of self is in fact a product of contingencies and partial struggles that were not natural, national, essential, or inevitable" (8). In other words, the Virgin is not a static, unifying reflection of Cuban identity, but rather a dynamic, contested symbol of cubania that responds to the changing needs of her devotees. 


\section{CHAPTER 5:}

\section{THE FLUIDITY OF OCHÚN: REFLECTIONS OF CUBANÍA}

Jorge and Isabel Castellanos argue that pilgrims to the Virgin of Charity's shrine in El Cobre, Cuba can be divided into three groups: orthodox Catholics who come to venerate the Virgin, strict practitioners of Santería who come to worship the goddess Ochún, and those who oscillate between both cults (268). This third group represents the majority and therefore cannot be ignored in any ethnographical analysis of devotion to La Virgen de la Caridad. Despite the fact that the Catholic Church hierarchy considers Santería to be "Afro-Cuban witchcraft" (CRECED 93) and Ochún devotees to be "in error" (Tirado 4), an understanding of Ochún's significance is necessary to fully understand her Catholic counterpart, La Caridad, in popular Cuban and Cuban American Catholicism.

This chapter addresses the following questions: 1) How does Ochún meet the needs of her "children"? and 2) What does Ochún reveal about Cuban national identity? Ochún, like identity itself, is dynamic, multidimensional, complex, and most importantly, fluid. Like the Virgin of Charity, Ochún is also a symbol of cubania, yet as long as her devotees are considered to be in "error" in orthodox Catholic eyes, Cuban identity will remain contested. Ochún's fluidity, however, will ultimately enable her cult to flourish, no matter what obstacles are placed in the many paths of her devotion by Catholic hierarchy. As the Yoruba goddess of rivers, Ochún will continue to flow, meeting the many spiritual, social, cultural, and economic needs of her children, meanwhile affirming the unique identity of those Cubans who venerate her. 
The story of Ochún ${ }^{15}$ begins several centuries ago among the Yoruba people of present-day Nigeria, where she was revered as the goddess of the river that today bears her name (Castellanos, Cultura afrocubana 49). Ochún became one of the most powerful orishas in the Yoruba pantheon. According to the Yoruba belief system, orishas are intermediary divinities who govern the forces of the universe and give spiritual strength; they are "personifications of ashe that can be put at the disposal of human beings who honor them" (Murphy, Santería 11). A key principle in their complex religious belief system, ashe is defined as "the life force of God, the orishas, and nature" (175).

Each orisha is in charge of a particular domain of human existence. Ochún, for example, is commonly labeled as the "river goddess," the "fertility goddess," or an "African Venus" (Murphy and Sanford 2). Her significance, however, transcends these convenient labels. For the Yoruba, Ochún is the vital source of life; without her sanction, "no healing can take place, no rain can fall, no plants can bear fruit, and no children can come into the world" (18). Ochún's name, in fact, means "source"; she is viewed as "the perpetually renewing source of life" (3).

As the most powerful female deity of the Yoruba pantheon, Ochún accompanied her enslaved children across the sea during the transatlantic slave trade. During a series of civil wars at the beginning of the nineteenth century, thousands of Yoruba people were enslaved and sent to Brazil, Cuba, and elsewhere in the Americas in order to meet the insatiable labor demands of the sugar mills (Murphy, Santeria 21). African slaves were brought to Cuba as early as 1511 , the most intense period of the slave trade being

\footnotetext{
${ }^{15}$ Ochún is a "Cubanized" spelling. The African version of her name is Osún.
} 
between 1762 and 1838 (Knight 10). During these years, over 400,000 slaves were brought to the island, the majority from the west coast of Africa (48). ${ }^{16}$ The intensification of the slave trade in Cuba created profound demographic changes: while the slave population in 1774 was only 44,300 , by 1841 it had increased to 436,500 -over $43 \%$ of the island's entire population (Knight 86 and Curtin 34).

The effects of the slave trade, however, were far more than demographic, for the importation of slaves would forever alter the island's culture, especially as the Yoruba slowly replanted the ways of ashe in the New World. Despite the catastrophic consequences of the mass and brutal enslavement of the Yoruba, their orishas survived. As the Yoruba people faced the horrors of slave life in nineteenth-century Cuba, they relied heavily on the spiritual power of the orishas, and found new ways of keeping the deities alive. In this sense, religion served as a social support system for the slaves, "since it was instrumental in giving the African slaves and their descendants a sense of identity" (Sandoval, "Afro-Cuban Religion in Perspective" 91).

According to Joseph Murphy, the orishas were able to survive for three principal reasons: 1) the flexibility of the Yoruba religious heritage; 2) the social environment of colonial Cuba; and 3) the influence of the Roman Catholic Church (Santería 105). Although slaves were required to be baptized and instructed in the principles of Catholicism, traditional Yoruba religion survived because of its adaptability. Unlike the Catholic Church, this tradition is theologically flexible and has no institutions to define

\footnotetext{
${ }^{16}$ The percentage of Yoruba is impossible to determine, due to the fact that the region of the ships' embarkation in Africa was not always documented. An educated guess, however, can be made through an analysis of census data of slaves captured and returned by the British Navy along the West African coast. For example, according to an 1848 census of recaptives, over 7,000 of the 13,273 slaves included in the sample were Yoruba (Curtin 245).
} 
orthodoxy. In the opinion of Murphy, the genius of Yoruba religion is its ability to adapt; it is a fluid religion whose orishas are dynamic and therefore able to survive in new environments ("Yeyé Cachita" 98).

Another significant factor in the survival of the orishas in Cuba is the creation of cabildos, societies of blacks organized by the Catholic Church for the purpose of religious instruction. Ironically, these societies enabled the survival of the Yoruba religion, despite the fact that they were intended to serve as a social base for catechizing slaves. The final factor of the orishas' survival, according to Murphy, is the hagiocentric nature of Cuban Catholicism. As Miguel Ramos writes, "Roman Catholicism bears a very close resemblance to Yoruba religion, especially...the 'cult' of the saints" (54). The common belief in "petitionable intermediaries" thus provided a means of adaptation. For Murphy, "the saints provided symbols behind which the orishas could live on.... Catholic symbolism provided a haven for the orishas, symbolic building blocks to recreate the way of the orishas in the New World" (Santeria 114).

Due to these three factors, the Yoruba vision gradually changed to reflect the Catholic worldview that was forced upon the slaves. In a sense, slaves took possession of Catholicism; they appropriated and transformed the religion within their own universe. In the words of Murphy, "a new bilingual tradition emerged, at once a resistance to Catholic oppression and an accommodation to Catholic values" (Santeria 32). This new Cuban tradition is generally called Santería, "the way of the saints," because devotions to the orishas were carried out beneath the images of the saints. ${ }^{17}$ As this tradition emerged,

\footnotetext{
${ }^{17}$ Santería is also called La regla de ocha, ("the rule of the orishas"), La regla lucumi, or simply Lucumi, in reference to the name for Yoruba people in nineteenth-century Cuba. See "The Geographic, Ethnologic, and Linguistic Roots of Cuban Blacks," by Jorge and Isabel Castellanos for more information on the origin
} 
each African orisha came to be identified with a particular Catholic saint. Ochún, for example, was understandably associated with La Virgen de la Caridad -- another powerful female deity who emerged from the water to guide her spiritual children.

The dynamics of the syncretic relationship between orishas and saints are complex. Although a fully-detailed exploration of syncretism is not the objective of this chapter, a brief discussion of the topic can reveal useful insights into the nature of the relationship between these religious symbols. ${ }^{18}$ In religious terms, syncretism is defined as the fusion of different systems of belief; for example, the syncretic relationship between Ochún and La Caridad involved the interaction of Yoruba and Catholic religious traditions. This correspondence between African deities and Catholic saints is one of the most basic of syncretic processes.

In general, syncretism is a contentious and contested term. While some view religious syncretism as a form of resistance to cultural domination, others view it as a disparaging, ethnocentric label used to distinguish "impure" traditions (Shaw 8). Adherents to the second view contend that syncretism implies contamination, "the infiltration of a supposedly 'pure' tradition by symbols and meanings seen as belonging to other, incompatible traditions" (8). For example, the Catholic Church's definition of syncretism refers to "syntheses where they perceive that the Truth of the Christian message is distorted or lost" (11). These contested views of syncretism make this arena "a deeply politicized site of difference" (8). This political nature of syncretism is clearly

\footnotetext{
of the term "Lucumí." Many practitioners of Santería reject this term for its implications of Catholic dominance, and prefer to call their religion La regla de ocha or Lucumí.

${ }^{18}$ For more information on the importance of syncretism in Caribbean religion, see Anthony StevensArroyo, "The Contribution of Catholic Orthodoxy to Caribbean Syncretism: The Case of la Virgen de la Caridad del Cobre in Cuba."
} 
reflected in the contested meanings of La Caridad's symbol, which will be analyzed in greater detail below.

Despite the negative connotations of the word, syncretism is essential to consider in any analysis of La Caridad. There are three ways to characterize the syncretism of African deities and Catholic saints: synthesis, symbiosis, and dissimulation (Rey, Our Lady of Class Struggle 207). Theories of synthesis maintain that the fusion of the two religious systems results in the formation of a third religion (207). In other words, the Yoruba slaves in Cuba found Catholic symbols so compelling and powerful that they created a new religion, Santería, in which the "constituent elements have so far coalesced into a single whole that they are no longer individually recognisable" (Bastide 83). Thus according to this view, Ochún and La Caridad fused into one deity. Yet as many scholars maintain, it is erroneous to assume that Africans lacked awareness and naively believed that the saints and orishas were one (Pérez y Mena 8).

Contrary to the synthetic approach, the symbiosis perspective does not maintain that substantial fusion occurs (Rey, Our Lady of Class Struggle 207). Rather, elements from the two traditions exist side by side as part of a mosaic; true fusion is impossible because the beliefs of each system are solid and unalterable (Bastide 82). Symbiosis is thus defined as "the spatial juxtaposition of diverse religious traditions... which coexist without fusing with one another" (Desmangles 8). In nineteenth-century Cuba, this juxtaposition involved the identification of Catholic saints with African deities based primarily on visual associations. The choice of a particular saint to correspond to a specific god was often based on the similarity of symbols between Catholic and African iconographies; thus lithographs depicting saints played a crucial role in the symbiosis of 
the two systems (172). In the case of La Caridad, her beauty in lithographs is perhaps one of the most significant reasons that African slaves began to associate her with Ochún, often perceived as a beautiful young woman. ${ }^{19}$ Despite this visual association, however, symbiosis theories would maintain that no genuine fusion occurred. According to this view, Ochún and La Caridad, although visually connected, remained separate in the minds of slaves. Operating side by side in such a complex mosaic, each symbol maintained its own individuality and function. In a sense, the Virgin of Charity became a co-mediary with Ochún -- yet each deity remained distinct.

Proponents of dissimulation, on the other hand, maintain that Catholic symbols such as La Caridad were merely used to mask African religious traditions that were illegal during the era of slavery (Rey, Our Lady of Class Struggle 214). According to this view, slaves saw no religious value in Catholic symbols, used as "instruments of concealment in attempts to mask and thereby perpetuate otherwise threatened African traditions" (214). Proponents of this view maintain that Catholic saints are merely a "shell" to contain the African deities. Although slaves publicly stated that saints and orishas were one and the same, they simply said this to conceal their true beliefs (Pérez y Mena 4). While the need to conceal African religious practices certainly played a role in the identification of Ochún with the Virgin of Charity, it is erroneous to assume that Catholic symbols did not appeal to slaves on a more profound level. Syncretism is not "simply a mask put over the black gods for the white man's benefit" (Bastide 154); it is far more complex.

\footnotetext{
${ }^{19}$ Other factors must be considered besides the visual association. In La Caridad, the Yoruba encountered several characteristics shared with Ochún, including her association with water, copper, healing, and motherhood. See Cabrera, page 55.
} 
The above exploration of perspectives on syncretism reveals the complexity of the issue. One of the most crucial issues of the syncretic relationship between La Caridad and Ochún is the extent to which their visual association implies a corresponding syncretism of the spiritual beings whom they represent. The reality of this correspondence is not uniform; for some, Ochún and La Caridad have fused into one deity, yet for others, the two symbols remain distinct pieces of the mosaic. Although the Virgin of Charity may have initially been merely a mask to conceal the worship of Ochún from slave owners, La Caridad's significance among the Yoruba in Cuba gradually transcended the realm of concealment as they realized the genuine spiritual power of the Virgin.

Although the association between a Catholic virgin and a flirtatious goddess of love may seem an anomaly, the relationship makes sense when the maternal nature of both symbols is taken into consideration. In La Caridad, the Yoruba encountered a compassionate mother who loves and protects her spiritual children, in the same way that Ochún guides her devotees. In addition, the Yoruba encountered a morenicita (a brownskinned girl) who miraculously appeared to save people of color from a storm; in this sense, La Caridad was "one of their own"-- they appreciated her power to heal, soothe, and fight for her marginalized children (Murphy, "Yeyé Cachita" 88). Thus the Yoruba in Cuba did not pretend to venerate her; they did, in fact, recognize the spiritual power of La Caridad.

The complexity of the Caridad/Ochún relationship is based on the deities' simultaneous similarity and difference. At the same time that Ochún is visually represented by the Virgin of Charity, the Yoruba goddess retains her distinct personality. 
As Murphy writes in his essay "Yeyé Cachita: Ochún in a Cuban Mirror," the two religious symbols "are both the same and not the same.... Ochún both is and is not La Caridad" (94). Because each symbol maintains its individuality and distinctive character, their relationship is primarily symbiotic. Yet it can also be considered synthetic in the sense that the Virgin of Charity is one of the many manifestations of Ochún. As Murphy maintains, saints are "ways that the orishas manifest themselves to the Catholic world. Just as the Catholic Church believes that the Virgin Mary manifests herself in different ways to different cultures,...the orishas are capable of appearing to ordinary Catholics as pallid white saints and to santeros as the invisible forces of ashe" (Santería 40).

In other words, La Caridad can be considered a camino of Ochún. Devotees of Santería use the term camino, or path, to express the multiple guises of orishas (Castellanos, "A River of Many Turns" 34). Although one must keep in mind that the Virgin's significance transcends this interpretation of her as a path of Ochún, exploring the concept of caminos reveals useful insights into the nature of the goddess. Afro Cuban orishas are not simple, monolithic entities; rather, they "express a multiplicity of often contradictory meanings" (34). They are not individuals, but sets of personalities or paths that reflect different domains of human experience (34). Thus Ochún has various caminos, including La Caridad.

\section{The Caminos}

As the above exploration of Ochún's historical roots and syncretic nature reveals, she is a fluid, complex, and dynamic goddess. As Ysamur Flores-Peña writes in "Overflowing with Beauty," Ochún is an "image of constant flow and change" (113). It is precisely her fluidity that enabled not only her survival in the New World, but also the 
world-wide spread of her cult. Although her principal shrine is in Osogbo, Nigeria (Badejo 6), today Ochún is worshipped around the world, in such cities as Rio de Janeiro, Havana, Miami, and New York (Murphy and Sanford 4). There exist multiple traditions of Ochún, each of which is distinct; therefore, she cannot be categorized in any single way because each locale and each individual recognizes Ochún in unique ways (6). In Brazil, for example, there are sixteen caminos of Ochún, or Oxúm, as she is known there (Castellanos, "Four Women in the Life of Changó" 32). Thus "the images alluding to her presence and power are as diverse as the people and the geographical locations where she is worshipped" (Murphy and Sanford 10). These multiple Ochúns arise out of the experience of many communities, thereby revealing that her symbol is socially constructed to meet the needs of her devotees.

It is also important to realize, however, that within each of these single traditions a diversity of interpretations is possible. Thus Ochún is multidimensional not only among different traditions, but also within each tradition. In the case of Cuba, Ochún has five principal caminos, each of which responds to the particular needs of her spiritual children. Initiates in her cult will belong to one of the following five paths (Castellanos, "A River of Many Turns" 35):

1. Ochún Ibú-Akuaro: a beautiful young woman who epitomizes sensual love;

2. Ochún Ololodí: a serious homemaker who enjoys sewing;

3. Ochún Ibú-Kolé: a powerful sorceress;

4. Ochún Yumú: a rich, old woman who is deaf; and

5. Ochún Ibú-Aña: the queen of drums.

These paths reveal profound contradictions: Ochún is simultaneously young, old, rich, poor, ugly, and beautiful. Despite the diversity of these caminos, devotees insist that 
there is only one Ochún. In a sense, her divergent paths reflect the contradictions that are an inescapable aspect of the human condition (Castellanos, "A River of Many Turns" 37). Thus it is possible for Ochún to be perceived as a young, beautiful mulata with many lovers, who enjoys music and dancing, celebrates the joy of living, and is skilled in seduction, while simultaneously being perceived as a deaf old woman. Despite her many caminos, she is "almost always portrayed as the essence of female sexuality and joie de vivre" (Castellanos, "Four Women in the Life of Changó" 32).

In light of Ochún's multidimensional, dynamic nature, Isabel Castellanos writes that she is "a river of many turns" ("A River of Many Turns" 42). "Like the river," Castellanos writes, "she is constantly moving, eternally pursuing a path. Ochún represents the constant flow of human life" (39). Furthermore, like a river, she is unpredictable: "she can be placid and contented, flowing and gracefully nurturing and nourishing those who worship and indulge her.... Yet there is also the other face of the goddess...the raging river" (Flores-Peña 114). Unlike the Virgin of Charity, Ochún is not always forgiving (Castellanos, "A River of Many Turns" 40). She is kind but quick to take offense, demanding, capricious, vindictive, and stubborn (40). This irony reveals the fact that "Afrocuban wisdom is based upon a profound dialectical view of... reality" (42). Thus devotees recognize that "there is no life without death, no good without evil, no love without hate, and no infirmity without health. The goal of the followers of the orichas is not to obliterate or to simplify these paradoxes, but to accept their indeterminacy and yet learn how to orchestrate them into a favorable, vital balance" (42). To achieve this spiritual balance in a complex world, devotees depend on Ochún for guidance. Thus one of the principal needs that Ochún meets is the need for spiritual 
balance, ironically made possible by the fact that she is "a river of many turns." Through an appreciation of Ochún's complexity, devotees are able to appreciate the paradoxes of life itself. They realize that although she may assist them in achieving a favorable spiritual balance, the contradictions of life will always persist.

Just as Ochún herself is multidimensional, so too is her power, thereby enabling the goddess to meet the basic needs of her various and abundant children. Like all orishas, she assumes a parental role and tends "to treat a devotee as a mother would her child" (Ramos 58). In addition to a maternal figure, Ochún also serves as a guardian angel for her devotees (Flores-Peña and Evanchuk 8). ${ }^{20}$ To her children, Ochún offers "the good things in life, health, wealth, and love," but she brings them in certain ways that must be followed in order to receive her blessings (Murphy and Sanford 7). Rituals are thus a crucial component of her devotion. Through ritual divination, devotees acquire knowledge of their destiny and specific models of action in order to take advantage of it (Murphy, Santería 135). In these rituals, "the orishas speak to human beings, diagnosing their needs and opening their destinies to fulfillment" (135). Many of the rituals often focus on a specific problem of the devotee. Because most of Ochún's children are poor, the problems are usually practical and involve money, health, or love (134).

In this respect, Santería is a practical religion that enables its practitioners to deal with life's daily struggles. As Katherine Hagedorn writes, one can look at Santería "through the lens of resolver," the resolution of problems (212). Its practicality is thus one of the primary reasons for the swelling number of practitioners in Cuba following the

\footnotetext{
${ }^{20}$ Individuals do not choose their particular orisha -- this knowledge is acquired by divination. Once the orisha is revealed to devotees, that deity remains their particular patron forever (Flores-Peña and Evanchuk $8)$.
} 
beginning of the "Special Period" in 1990 (220). Ochún and the other orishas are a means for Cubans to deal with the struggles of daily life that have intensified since 1990 . As Mercedes Cros Sandoval observes, the feelings of powerlessness experienced on the island have resulted in "the resurgence of a greater reliance on magical systems" ("Santería" 628). In a sense, Ochún serves as a financial advisor/physician/psychiatrist for those who cannot afford such conventionally costly services. Devotees believe that nearly all problems can be resolved by deepening their relationship with Ochún; therefore, her symbolic strength resides in her ability to meet all the needs of her children.

One of the most important aspects of Ochún's power is her ability to soothe and heal her devotees. As the goddess of rivers, Ochún's main curative agent is water. Used ritually by her children, water is believed to eliminate tension, heal ailments, and create a sense of inner harmony and peace (Murphy and Sanford 25). In ceremonies of devotion, water is a thus a reflection of the soothing power of the goddess' fluid nature. Like water, she brings spiritual refreshment.

Another significant aspect of Ochún's power is her maternal nature. As ruler of the organs by which conception is possible, she assists women who desire to become pregnant (Castellanos, "A River of Many Turns" 42). In a sense, she epitomizes the ashe of motherhood, and symbolizes the power of mothers to help communities cope with whatever problems they face. In the case of Cuba, perhaps one of the greatest problems faced is the existence of contested notions of Cuban identity. Although Ochún may have the power to soothe and unite her own devotees, does she have the power to heal and 
unify all Cubans? Is she truly "the mother of all Cubans," as some suggest? The next section of my thesis will explore this complex yet necessary question.

\section{The Caminos of Cubania}

Another aspect of Ochún's power is her importance in negotiating social identity. As a religious symbol, she reflects the identity of those who venerate her. In a sense, Ochún is a mirror in which devotees see themselves. The construction of this mirror is largely determined by the needs of the community, by practical concerns such as the need for money, health, love, and spiritual balance, as discussed above. Yet the mirror can also reflect the desire of individual devotees for an affirmation of their identity. In the case of devotees of Ochún, their devotion reflects their desire to be "Cuban" in their own way, in ways sometimes radically different from the Marian devotion of their compatriots. In the same sense that they have constructed their own version of Ochún, they have constructed their own sense of cubania by choosing to practice Santería. As a reflection of the never-ending process of identity construction, Ochún herself can be considered "a symbol in process, an unfinished complex of meanings, images, and experiences reflecting the unsettled, contested questions of race" (Hale 227).

These contested questions of race did not end with the abolition of slavery in Cuba in 1886. Since the emergence of Santería in the nineteenth century, secrecy has been necessary among its practitioners, due to a social environment of racial prejudice and oppression. ${ }^{21}$ In the minds of Cuba's white elite, Santería was associated with superstition, criminality, and laziness; until 1940, in fact, its practice was a punishable

\footnotetext{
${ }^{21}$ For more information regarding the evolution of Santería after independence and before the revolution, see George Brandon, Santeria from Africa to the New World.
} 
crime (De la Torre, "(N)either the (M)other..." 844). Placed in the historical context of modernization, Afro Cuban religion was often viewed as irrational witchcraft (Palmié 7). Persecution continued after the revolution of 1959 -- black Cubans on their way to religious ceremonies were often stopped and physically or verbally harassed by the police (Hagedorn 9). Despite the various government-sponsored research projects on African religious traditions in the 1980 s, the harassment of Santería practitioners continued (9).

Although persecutions abated somewhat in the 1990 s, primarily because of the government's discovery that Santería could be commodified to produce tourist dollars, Catholic priests continue to believe that practitioners must be "corrected" so that they can embrace the "official" faith (De la Torre, "(N)either the (M)other..." 841). According to Catholic orthodoxy, devotees of Santería are confused practitioners of an "impure" religion (841). Yet despite the attempts of Catholic officials to religiously purify Cuba, about one out of every four Catholics occasionally consulted santeros (priests of Santería), according to a 1954 study commissioned by the Cuban Catholic Church (De la Torre, The Quest for the Cuban Christ 56). Thus although the tenets of Santería will always be theologically challenged by Catholic orthodoxy, its influence on Cuban identity cannot be ignored. While the religion originated among African slaves on the island, its flexibility and practicality has appealed to Cubans of all colors throughout the twentieth century, as is evident in the 1954 study.

The revolution of 1959 resulted in the spread of Santeria from the island to exile. Just as Ochún accompanied her children from Nigeria to Cuba, so too did she accompany her children who immigrated to the United States in the twentieth century, whether for political or economic reasons. In the words of Robert Farris Thompson, "her strong 
presence was a blessing for followers subjected to forced migration," for "in the midst of circumstance, she keeps tradition flowing like the depths of the river in which she dwells" (251). As Sandoval writes, Ochún and the other orishas crossed the Florida Straits "to console, cure, and advise their children" (La religión afrocubana 270). Not only has Santería survived in exile, but it has flourished, primarily because of its flexibility and its ability to meet the practical needs of followers, many of whom are white Cubans (273). ${ }^{22}$ In order to deal with the disorientation of exile, many Cubans in Miami -- of all races -- are increasingly attracted to Santería as "a mental health care system" (Sandoval, "Santería as a Mental Health Care System" 137).

Meanwhile, hostility towards Ochún, and Santería in general, continues among some members of the predominately white, middle-class Cuban exile community of Miami. In the eyes of some Cubans, the Virgin of Charity "has come to stand for a prerevolutionary Cuba of the heart, a warrior to win back the island from tyranny" (De la Torre, "(N)either the (M)other..." 857). Ochún, consequently, represents a threat to their struggle because she has the potential to disturb the pre-revolutionary social order in which middle-class whites enjoyed a position of power and privilege. Although most visitors to La Caridad's shrine in Miami know little about Ochún except that she "has something to do with Santería," some are openly hostile towards the religion and believe it is a source of embarrassment. Anabel, for example, is a 39 year-old white female who believes that Santería is not only witchcraft, but also the cause for Cuba's oppression. ${ }^{23}$

\footnotetext{
${ }^{22}$ For more information on the reasons why Santería has flourished in exile, see Mercedes Cros Sandoval, La religion afrocubana, pp. 270-74.

${ }^{23}$ Personal interview conducted at the Ermita (October 26, 2003)
} 
Clergy at the shrine in Miami, meanwhile, preoccupy themselves with evangelization; they desire to purify Catholicism, viewing baptized Catholics who are influenced by Santería as ignorant (Tweed 44). The Catholic hierarchy thus tries to denigrate Afro Cuban religion as "a sphere of ignorance and impurity" (De la Torre, The Quest for the Cuban Christ 57). Catholic clergy therefore attempt to reveal the "Truth" of Catholicism to practitioners of Santería. ${ }^{24}$ In the words of Monsignor Román, "we have to preach the Catholic faith... we have to expose clearly the truth, what one has to believe" (Tirado 5).

Devotees of Ochún who visit the Miami shrine are often asked to leave, but it is not always possible to visually distinguish those who venerate the Santería goddess, as I discovered during my fieldwork at the shrine. For example, I interviewed Teresa, a 17 year-old mulata born in the United States, after she attended a Mass for a deceased relative. Based solely on her appearance and her participation in the Mass, a priest would probably not be able to discern that she considers herself "a daughter of Ochún, ever since I was born." 25 Despite their fervent desire to evangelize, clergy at the shrine will never be able to eradicate the influence of Santería, whose growing influence among white Cubans in Miami is undeniable.

In light of the Catholic Church hierarchy's attitude toward Santería, Miguel de la Torre's assertion that the relationship between the Virgin of Charity and Ochún "has the potential to inspire a theology of reconciliation" is too idealistic ("(N)either the

\footnotetext{
${ }^{24}$ According to the canon law of the Catholic Church, evangelization is a duty of all Christians, "so that the divine message of salvation may increasingly reach the whole of humankind in every age and every land" (143).
}

${ }^{25}$ Personal interview conducted at the Ermita (November 15, 2003) 
(M)other..." 838). De la Torre believes that as the "Mother of all Cubans," La Caridad/Ochún represents the potential of reconciliation not only between blacks and whites, but also between Cubans in exile and on the island. He writes that she can serve both as "a catalyst for reconciling the two Cubas" as well as "a witness against the dominant white Cuban elite who reconstruct her image in a way that masks their own power and privilege" (838). Not only is this belief idealistic, but it is also simplistic in the sense that there are not "two Cubas," as he contends. His division of Cuba based solely on geographical factors is most tenuous, for when race and class considerations are taken into account, one realizes that there are in fact many Cubas.

De la Torre is correct, however, that in Santeria "there are rich resources for understanding Cubans that provide a healing response to the rupture" (838). Although most white, middle-class Cubans know little about Santería, an exploration of its beliefs can reveal insights into the many dimensions of Cuban identity. Although Santería may be naïve syncretism to some, in reality it is "a sophisticated attempt to account for the possibility of truth in multiple forms" (Murphy, Santeria 124). The existence of truth in multiple forms, however, is certainly not recognized by the Catholic orthodoxy or by those white, middle-class exiles who view Santeria as witchcraft and Catholic doctrine as the Truth. Devotees of the orishas, on the contrary, believe that multiple truths are possible. In the case of Ochún's complex relationship with La Caridad, they recognize that neither identity is the "true" one because both are true (Murphy, "Yeyé Cachita" 94). When applied to the concept of Cuban national identity, this perspective is illuminating; just as there are many ways to understand Ochún, so too are there many caminos of 
cubania. In other words, there is not one "true" way to be Cuban; all individuals have the right to construct their own Cuban identity.

As long as some Cubans believe that Santería is witchcraft, however, cubanía will remain a contested notion. Therefore, true reconciliation remains highly unlikely until all Cubans embrace the possibility of multiple truths, of multiple ways to be Cuban. Although the future of a unified Cuba is uncertain, and perhaps impossible, the future of Ochún remains certain, in my opinion. As this section has revealed, Ochún's fluidity explains why she has remained relevant to her devotees in the midst of dramatic social changes. As Castellanos writes in "A River of Many Turns," Ochún has "survived and flourished under conditions as varied as those brought on by slavery, freedom, tyranny, democracy, and exile" (36). Her flexibility explains both her survival despite slavery and persecution as well as the spread of her devotion to new societies such as the United States. In the future, her complex, dynamic, fluid, and multidimensional nature will enable her to survive, no matter what obstacles are placed in her caminos, for "with each new social environment Ochún will contract and expand, ebb and flow, conceal and reveal" (Murphy, "Yeyé Cachita" 98). Like the water of a river, she will continue to flow, always the same and always different, offering spiritual refreshment, practical solutions to life's daily problems, and most importantly, a reflection of la cubanía. 


\section{CHAPTER 6:}

\section{A COMPARATIVE ANALYSIS OF LA CARIDAD'S CURRENT SIGNIFICANCE}

This chapter compares the present cultural and political significance of the Virgin of Charity in Miami and Cuba. The first section presents descriptions of her feast day celebrations in exile and on the island. While my description of Miami is a first-hand account, the description of Cuba is based on observations and interviews I conducted in December 2003 in El Cobre, as well as on Olga Portuondo Zúñiga's account of past feast days and publications of the Archdiocese of Santiago. Following both accounts, I then offer reflections on the differences between the celebrations. The final section of this chapter presents an analysis of the interviews I conducted in Miami and Cuba.

\section{MIAMI}

September 7, 2003

After driving past the dozen or so road-side flower stands, filled with yellow carnations and sunflowers for sale, I arrive at the ermita on a Sunday afternoon, the day before the Virgin's feast day, part of a steady stream of cars entering the grounds of the shrine. Approaching the shrine, the conical design is impressive, a reflection of the Virgin's mantle. On the door of the ermita I immediately notice a "welcome" banner with the following words from Psalm 118:

This is the gate of the Lord. Only the righteous can come in.

I wonder who meets the requirements of righteousness to enter the shrine. Despite the implications of exclusivity, the interior is filled with about 150 people. Some people are praying in silence, kneeling and gazing at the Virgin, yet others are chatting with friends, not paying any attention to the altar. There is a lot of commotion, and I wonder if some 
find it difficult to pray to the Virgin in silence, for the scene seems more like a social event than a religious celebration.

Immediately upon entering the shrine, my eyes are drawn to the mural behind the altar. In a sense, the images visually transport the viewer to Cuba: the shrine in El Cobre; the Cathedral of Havana; the shield of Cuba; the mogotes of Pinar del Rio; the faces of Félix Varela, José Martí, Máximo Goméz, Antonio Maceo. Although described by its creator as "The History of Cuba in a Glance," there are no references to Batista or Castro. The most prominent image, of course, is the Virgin herself, who appears to be at the center of all Cuban history.

I notice people of all ages -- about half are older females, but there are also many families with young children and three pregnant women. Many people wear yellow, the favorite color of La Caridad, according to popular tradition, ironically rooted in the cult of Ochún. Of all the people inside, only a dozen or so are black. I soon notice Monsignor Román walking around to greet visitors, who shake his hand or even kiss his ring as a sign of respect. In the center aisle, there is a long line of people waiting to spend a few moments as close to the Virgin as possible, as well as a line of people in the shrine store, waiting to buy rosaries and medals. Next to the altar there are t-shirts with the Virgin's image for sale, as well as a banner with the words: "To Jesus through Mary." Near the entrance there is a display case with various pamphlets about the history of the shrine and the "truths of the Christian faith."

As I take my seat near the back of the shrine, Monsignor Román approaches the podium and begins to bless rosaries and medals. He explains the significance of the rosary and the history of devotion to La Caridad, emphasizing her role as Mary, the 
Mother of God. His passion for evangelization is clear. After the blessing, petitions are made for a Cuba libre, for the freedom of all Communist countries, for the evangelization of all Cubans, and for the sick. I decide to observe the people outside and as I leave the interior, I see at least one hundred bouquets of yellow carnations and sunflowers in a pile by the exit door. Placed by pilgrims on the altar, the flowers are immediately removed by workers at the shrine.

Outside by the bay, some people are sitting alone on the wall, staring at the horizon, while others have set up lawn chairs on the grass, to rest and chat with their families. Soon a procession emerges from the interior, led by Román, around the shrine's property. The Virgin is placed on the back of a pick-up truck, and the people follow slowly behind, singing hymns to La Caridad. I walk around the grounds, noticing the prevalent evocations of Cuba -- the mural of Cardinal Jaime Ortega, the current Archbishop of Havana; the statue of Félix Varela, a Cuban bishop and scholar who died in 1853; the monument to the martyrs of the homeland with busts of Martí and Varela and quotes about the importance of being a religious nation. But perhaps the most powerful reflection of the patria is the water itself. Beyond the horizon of the bay lies the land of which these exiles have dreamed for decades. Although the horizon may appear serene, it cannot fail to evoke painful memories of the past, for it is this water that physically separates exiles from their homeland. On the other hand, the horizon also represents the never-ending dream of a future Cuba libre.

September 8, 2003

I once again return to the shrine in the late afternoon, just before the Virgin is transported to the American Airlines Arena by boat. Slowly the grounds of the shrine 
begin to fill with people, eager to see La Caridad leave. A local Spanish-language news station captures the scene on film. On the bay waits the Virgin's boat, draped with a Cuban flag. Like yesterday, people have set up lawn chairs by the water, a place to relax and contemplate the horizon. Over the loudspeakers I can hear what is being said in the shrine. "This is a celebration," one of the priests tells the crowd. The people inside begin to sing:

$$
\begin{gathered}
\text { Y si vas a Miami, } \\
\text { Quiero que me traigas } \\
\text { Una virgencita de la Caridad, } \\
\text { Yo no quiero flores, } \\
\text { Yo no quiero estampas, } \\
\text { Lo que quiero es Virgen de la Caridad. } \\
\text { (And if you go to Miami, } \\
\text { I want you to bring me } \\
\text { A little Virgin of Charity. } \\
\text { I don't want flowers, } \\
\text { I don't want holy cards, } \\
\text { What I want is the Virgin of Charity.) }
\end{gathered}
$$

The words of the popular song have changed -- "El Cobre" has been replaced with "Miami" -- but the melody is the same. People by the bay begin to join in the song. Next to me is a white mother in her early $40 \mathrm{~s}$, with her 10 year-old daughter, both in yellow dresses. When the mother hears the song, she immediately begins to sing and teaches the words to her daughter.

A sense of anticipation is palpable among the crowd. Finally the Virgin appears, in a procession led by Román from the altar to the bay, and the people begin to clap. As La Caridad passes, some bless themselves. She is placed on the boat, which slowly pulls 
away and heads to the arena. The people wave good-bye and throw yellow flowers into the sea.

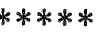

At the entrance to the arena, I am greeted with a multitude of medals and Catholic magazines for sale, as well as pamphlets about Radio Paz and the drive to canonize Varela. Inside a video is being shown with images from past celebrations of the Virgin's feast day, beginning in 1962. On the curtain behind the altar are a large Cuban flag and an image of St. Antonio María Claret, a nineteenth-century Cuban bishop. I take my seat in the upper section of the arena, and watch the steady stream of people enter the arena. About one-tenth of the growing crowd is dressed in yellow. As at the shrine, I notice few black Cubans. Ironically the image of the Virgin on the program cover is one of the darkest I have ever seen. Under her image are the Tres Juanes, here portrayed as two native Cubans and one black Cuban, and behind her are symbols of Cuba's six original provinces: Pinar del Río, Habana, Matanzas, Las Villas, Camagüey, and Oriente.

As expected, evocations of Cuba are prevalent. Following the images of past celebrations, the screens in the center of the arena begin to project images of Cuba: the mogotes of Pinar del Río, the statue of Jesus in Havana's Bay, and the Pope's 1998 visit, which elicits loud applause from the crowd. Soon begins the procession of various Catholic groups such as the Cofradia de la Virgen de la Caridad del Cobre, all of which take their reserved seats at the center of the floor. As the groups parade around the arena, Father Pedro Luis Pérez approaches the podium to begin the annual tradition of the rosary, which he has led every year since 1961. In between prayers, he tries to energize the crowd: ¡Viva Cristo el rey! ¡Viva la Virgen de la Caridad! ¡Viva Cuba libre! 
The people clap and cheer, but Father Pérez is not satisfied. ¡No se oye! So he repeats the litany, expecting them to cheer louder, which they do. iQue se caiga el comunismo! shouts Father Pérez. The people go wild. Songs are sung after each decade of the rosary, including Madre de nuestra esperanza ("Mother of Our Hope"). After each song, Father Pérez praises the Virgin, eager to maintain the energy of the faithful. "The Virgin of Charity is not only the Patroness of Cuba," he tells the crowd, which I estimate to be between six and seven thousand. "She is the Patroness of Miami, of Venezuelans, of Argentines, of Colombians, of everyone!" The people do not applaud. Apparently his desire to share La Caridad with other immigrants is not felt by all Cubans. ¡Viva Venezuela! ¡Viva Colombia! ¡Viva América del sur! ¡Viva Cuba libre!

As the rosary continues, the screens now project live images of the Virgin arriving by boat. The crowd erupts with applause, eager to be in the physical presence of La Caridad. A few minutes later, she enters the arena, led by Monsignor Román and six young girls carrying the Cuban flag, in white dresses with red flowers in their hair, symbols of the democratic republic for which these exiles long. As she processes throughout the arena, people begin to wave white handkerchiefs and sing La Virgen Mambisa. The woman next to me, a white female in her late 50 s, begins to cry as the Virgin is placed on her seat of honor in front of the altar. Before the Mass begins, both the American and Cuban national anthems are sung, and the keys of the city are presented to Monsignor Román in honor of his retirement after years of service as Miami's Auxiliary Bishop. Following the presentation, all the priests of the archdiocese process into the arena, and the Mass begins. 
After the introductory rites and the readings, Román approaches the podium to give his homily. He begins to talk in English, still a difficult language for him despite decades in the United States. "Why are Cubans so devoted to the Virgin?" he asks. "Because we have found Jesus in her arms." He repeats the same message in French, and then in Spanish. The people begin to clap upon hearing their native language. Román tells the crowd that he would like to focus on two exceptional Cuban exiles: Father Varela and Monsignor Eduardo Boza Masvidal, who recently died this past March. $\mathrm{He}$ talks about the exemplary life of Varela and then reads excerpts from Boza's Voz en el destierro: "According to his words, the Virgin is "the star of the sea that shines in the dark night, giving a ray of light and hope.' In a world of imbalance, she is 'Our Lady of Balance." Román finishes the homily by discussing the importance of faith in exile, and receives a standing ovation.

Following petitions for the Pope, a Cuba libre, all the nations of Latin America, the work of Román, all immigrants, the sick, evangelization, and world peace, various symbols are brought to the altar during the Preparation of Gifts, including a bouquet of yellow roses, a Cuban bohio, a book about Varela, and the rosary. After Communion, homage is paid to Román for his years of service. "Monsignor Román is our father in exile," says one of the cofradia representatives. "What would have become of us without him?" A video about Román's upbringing and achievements is shown, with photos of his boyhood in Matanzas, his arrival in Miami in the 1960s, and the construction of the ermita, as well as taped messages of congratulations from a cousin who still lives in Cuba and the Bishop of Matanzas. At the end of the video there are various images of Cuba: El Morro, the Malecón, the Hotel Nacional, the Cathedral of Havana, the Capitol, the 
beach of Varadero, the cathedral of Santiago, the shrine of El Cobre. A collective sigh emerges from the crowd, a sigh of nostalgia, bittersweet memories, and the overwhelming desire to see these places in person one more time. The video ends with an image of the Virgin herself in El Cobre, and the crowd gives her a standing ovation.

\section{CUBA}

September 8, 2003

Meanwhile in El Cobre, the birthplace of La Caridad's cult, approximately 15,000 devotees visit her shrine throughout the day, eager to see their spiritual mother in person. ${ }^{26}$ Amidst the majestic Sierra Maestra Mountains the cream-colored church rises dramatically, a beautiful sight for those Cubans from around the island who have made the journey to the spiritual heart of their homeland. Of all ages and colors, they arrive by bus, truck, car, motorcycle, on foot, and even by horse-drawn carriages, however they can, past the road-side flower stands and through the tiny town of El Cobre. Although most enter the sanctuary on foot, there are some who climb the dozens of steep stairs to the entrance on their knees, fulfilling a vow they have made to the Virgin. From the top of the stairs, the panorama of the pueblo below and the surrounding mountains is breathtaking. Near the principal door there are busts of Varela and Pope John Paul II, in commemoration of his 1998 visit, as well as a plaque of gratitude to the Virgin from the Independence War veterans, donated in 1928. Upon entering the church the pilgrims are greeted by a sign with a prayer upon entering the sanctuary: "Holy Virgin of Charity, Mother of all Cubans, I give you thanks for enabling me to arrive at your sanctuary to

\footnotetext{
${ }^{26}$ Figure given in a personal interview with a volunteer at the shrine in El Cobre (December 10, 2003)
} 
venerate you with all my heart.... Upon humbling myself before your image, may my love of God and my brothers grow, and may peace and joy abide in me."

After entering the church, the Cubans rapidly climb the stairs to the Virgin's sanctuary, where she stands on a pedestal in a glass-enclosed case above the altar. The space is small, with only a few pews, so they must struggle with the crowd if they wish to see the details of the Virgin's elaborately-decorated, gold-encrusted satin gown. Many bring flowers to offer La Caridad, everything from a single carnation or sunflower to elaborate bouquets. Some have brought their newborn babies to present to the Virgin for the first time; others have come alone to sit and pray in silence. In the front row sits a young Cuban boy, still in his school uniform, sitting next to his mother, gazing silently at the Virgin and telling her son to keep still and pray.

Throughout the day Masses are held by Father Jorge Palma, the director of the sanctuary. Part of an annual tradition, everyone in the shrine sings the Cuban national anthem when the homily concludes. They then sing the popular song:

Y si vas a El Cobre, Quiero que me traigas

Una virgencita de la Caridad,

Yo no quiero flores,

Yo no quiero estampas,

Lo que quiero es Virgen de la Caridad.

(And if you go to El Cobre,

I want you to bring me

A little Virgin of Charity,

I don't want flowers, I don't want holy cards, What I want is the Virgin of Charity.) 
In between Masses, Father Palma walks around the shrine to greet visitors. Around noon, a replica of the Virgin's statue is processed around the church, and the people try to get as close as possible, eager to touch the statue.

After visiting La Caridad in her sanctuary upstairs, many devotees descend to enter the Room of Miracles. Near the entrance there is a glass display case with objects left behind by grateful devotees, such as athletic medals and trophies, uniforms, coins, tshirts, and caps, as well as notes of thanks:

*'I give thanks to the Virgin of Charity for having played well in the championship basketball game of 2002. As I promised, here is my uniform."

*'I leave you my trophies so you continue giving me victories in life and to thank you for your help."

*"Many thanks for giving me the strength to win these prizes. With faith in you I will win more."

Inside the Room of Miracles the faithful can light a candle and leave behind a personal object or note of gratitude to the Virgin, many of which are still displayed from past years: "To the Virgin of Charity of El Cobre, mother of all Cubans, I leave in your sanctuary your image so you give health to my family and so you help my daughter in her studies. Thanks for always hearing my prayers, don't forget your children, give us health and open the path to Cubans." While this particular woman left behind a statue of the Virgin, other devotees have left behind an assortment of objects, including medals, rosaries, locks of hair, potpourri, baby clothes, watches, bracelets, and a wedding cake decoration. 
Other objects in the room are historical, such as the original wood tablet on which the Virgin was found in the early seventeenth century, the 1916 letter to Pope Benedict $\mathrm{XV}$ by Independence War veterans asking him to declare the Virgin as Patroness of Cuba, a collection of badges brought as promises to the Virgin by members of Castro's Rebel Army, and a painting of Pope John Paul II holding a Cuban flag, with the Virgin behind him. And some objects in the room are overtly political, such as a map of Cuba with the names of all prisoners of conscience listed in each province, as of June 2003. Next to the map there is a small banner with the words, "Amnesty for Political Prisoners," and a poster with the message: "Virgen Mambisa, for the liberty of political prisoners, we count on your support."

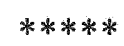

Other devotees prefer to attend Mass at the cathedral in Santiago, where they listen to Archbishop Pedro Meurice Estiú's homily, most of which contains biblical reflections on La Caridad as Mary, the Mother of God. At the end, however, the Archbishop discusses the Virgin's relationship with the Cuban people: "She is not content to be solely the Mother of all humanity, for she knows the identity and traditions of all countries," he tells the crowd. 27 "In this way faith and history are fused, making the Virgin and the Cuban nation inseparable." Later that day, at the feet of La Caridad in El Cobre, his words become more political, in an attempt to inspire change in Cuba: "With liberty, with sweat, we will be capable of building the Cuba that we need, and that we all desire... Let us ask the Virgin to help us understand each other...to leave behind our

\footnotetext{
${ }^{27}$ Homily printed in Iglesia en marcha, the official publication of the Archdiocese of Santiago.
} 
differences... and honestly compromise ourselves to build a Cuba that is great, beautiful, and free."

\section{$* * * * *$}

Today marks the culmination of the novena to the Virgin, which all Catholic Cubans have been encouraged to pray. Beginning on August 31, many have said daily prayers to the Virgin, asking her for spiritual guidance and assistance with a list of intentions made by the Cuban Catholic Church for the year $2003:^{28}$

1. For world and national peace.

2. For a profound and radical conversion of all Cubans.

3. For liberty in Cuba and national reconciliation.

4. For the Cuban family separated by exile and undermined by divorce and the lack of values, so it returns to its Christian roots.

5. For Cuban youths, that they live in accordance with the Gospel.

6. For all Cubans, that we live an authentic faith, not just in words.

7. For the political prisoners, so they are liberated. We especially pray for the persecuted and those incarcerated because of their political labor.

8. For exiled Cubans around the world, may those who desire to return to the homeland be able to do so.

9. For the sick, the old, and the children, especially for those who suffer in solitude and helplessness.

10. For our personal intentions: disease, plans, family, work, etc.

Several of these intentions are mentioned in the most recent pastoral letter of the Cuban bishops, released today throughout the island, on the tenth anniversary of the release of El amor todo lo espera. The decision of the bishops to release the letter on La Caridad's feast day is a significant reflection of the symbolic association between the Virgin and the need for change in Cuba. Entitled La presencia social de la Iglesia, the letter demands increased political, economic, and social freedoms. Although it is intended to offer Catholic Cubans theological reflections on the mission of the Church in

\footnotetext{
${ }^{28}$ List of intentions and novena posted on website of Cuban Catholic Church, www.cubacatolica.org
} 
society, the bishops do not refrain from condemning recent events such as the sentencing last March of 75 dissidents and the execution of three hijackers, acts which "have closed the path to liberty of expression and to understanding among Cubans."

In addition, the bishops condemn the increased restrictions placed on religion following the Pope's visit in 1998: "After the visit of the Pope, Cuba has increasingly experienced a return to the language and methods of the first years of the revolution." Tired of dealing with the restrictions of the regime, they demand the right to build new churches, the easing of restrictions on bringing new priests into Cuba, and access to means of communication and education. Furthermore, they demand increased economic freedom, and criticize the government for lapsing on the economic reforms begun a decade ago. It is this lack of economic freedom, they believe, that explains the "lack of hope, the daily burdens of survival, and the growing desire to emigrate," observed in the majority of Cuban people. Although the bishops insist that the goal of the Church is never to have political power, they recognize that "the Church cannot be neutral regarding the lack of liberty." And so the Cuban bishops have chosen the feast day of La Caridad to make their voices heard. They close the pastoral letter with an invocation of the Virgin:

With devotion we invoke the blessed name of the Virgin of Charity of El Cobre. Under her maternal protection we place ourselves. Like a loving mother, she is always aware of what is truly good for us, her dear children. To you, Mother, we offer with humility and simplicity the fruits of our reflection! Strengthened by this hope, let us work with patience, abnegation, and love, for the present and future well-being of our Homeland.

\section{Reflections}

The intensity of the Virgin's feast day celebrations on both sides of the Florida Straits cannot be overstated. The simple fact that thousands of Cubans in Miami were 
willing to fight downtown traffic on a Monday evening and thousands on the island were willing to find any means of transportation possible to El Cobre, clearly reflects this. The exact number of devotees who made the journey is unknown. According to a volunteer at the Virgin's shrine in El Cobre, approximately 15,000 devotees made the journey to see La Caridad in person. ${ }^{29}$ A similar estimate was given for the number of people who attended the $42^{\text {nd }}$ annual celebration in Miami, according to newspaper accounts in The Florida Catholic. El Nuevo Herald, however, estimated the number of those in attendance to be 4,000 , quite a significant difference. Although 15,000 is probably an exaggerated number for both El Cobre and Miami, the strength of La Caridad's cult remains significant.

On the surface, the celebrations in Miami and El Cobre may seem very different. While exiles arrive at the ermita in BMWs and Lexuses, Cubans on the island arrive by any means possible -- packed in the back of trucks or horse-drawn carriages. Differences in class are one of the most significant observations to consider. To a Cuban from the island, the spectacle of La Caridad arriving by boat, with live images of her transport projected on video screens, to an arena used for concerts and basketball games, might seem a bit overwhelming.

In addition to class, the other most significant factor of difference is race. A Cuban from the island, accustomed to celebrations in El Cobre, may find it difficult to believe that one can look around the arena and practically count the number of Afro Cubans on two hands. This difference is to be expected, however, when one considers the disproportionate number of white Cubans in exile. Although I was unable to attend a

\footnotetext{
${ }^{29}$ Personal interview (December 10, 2003)
} 
celebration in honor of Ochún, one must remember that such festivities were also being held on both sides of the Florida Straits.

The Catholic Church's mission to evangelize is evident in both Miami and Cuba. On the island this is reflected in the list of 2003 intentions, yet in Miami the passion for evangelization is more visibly evident in both the pamphlets about the truths of the Christian faith and in the figure of Monsignor Román himself. The absence of Santería practitioners is quite understandable when one considers the warning on the door.

Despite the significant differences in class and race, the similarities between the celebrations in El Cobre and Miami are striking. For both exiled and island Cubans, the shrines in Miami and El Cobre are spiritual centers of solace and reflections of national identity. Whether by the bay in Miami looking to the homeland beyond the horizon, or in the mountains of El Cobre on a site supposedly chosen by the Virgin herself, the locations of both shrines are highly significant for all Cubans. Both offer devotees lessons in Cuban history, whether through a mural of Cuban heroes or a room of miracles filled with historical objects. In both Miami and El Cobre, this attention to history is a reflection of both gratitude for past struggles and pride in being Cuban.

For exiles in Miami, however, the relationship between the Virgin and Cuban history takes on an added significance. The most important religious ritual for exiled Cubans, La Caridad's annual feast day celebration not only brings them together as a demonstration of gratitude for the Virgin's past assistance, but it also allows them to express their never-ending hope that Cuba will one day be free. The celebration is a powerful means to achieve unity in the diaspora. As Tweed writes in Our Lady of the Exile, the Mass is an act of collective remembering, for it enables exiles to celebrate the 
Virgin's role in Cuban history (132). More importantly, however, the Mass is an opportunity to express collective hope for the future of their homeland. Both retrospective and prospective, the Mass is "transtemporal" in the sense that it transports exiles back and forth in time, back to pre-revolutionary Cuba and ahead to the day when the dream of a Cuba libre is fulfilled (Tweed 117). The transtemporal nature of the event is clearly evident in the video of past celebrations and the repeated chants for a free Cuba. In the sense that it transports exiles back to the patria of their memories, the Mass is also "translocative" (Tweed 117). This is clearly evident in the various images of Cuba projected on the video screens throughout the celebration, images which elicited a collective sigh from the crowd.

The ability of the Virgin to return Miami exiles to Cuba -- at least in their imaginations -- is perhaps one of the most significant needs that she fulfills. Nowhere is this ability more evident than on the grounds of the ermita by the bay in Miami. Simply by watching a Cuban gaze at the horizon, one can begin to understand the intensity of the exile experience. Returning to an imaginary Cuba through the help of La Caridad is one way that exiles can deal with the trauma they have endured. As Monsignor Román stated in his homily, the Virgin is "Our Lady of Equilibrium" because she provides exiles a sense of balance in a world of increasing disorder. This balance is enabled by maintaining a connection with Cuba through La Caridad. In this light, the significance of the ermita's location by the bay becomes clear. As Tweed writes, "the symbols and practices bridge the water that separates exiles from their homeland and transport the diaspora to the Cuba of the exilic imagination" (139). At the same time that the Virgin's shrine allows exiles to return to their homeland by way of the imagination, devotion of $\mathrm{La}$ 
Caridad fulfills their undeniable desire to be Cuban. Going to the ermita is an effective means of asserting their Cuban identity in a foreign land, for by expressing devotion they simultaneously express their personal sense of cubania.

Whereas the ermita in Miami is both transtemporal and translocative, the sanctuary in El Cobre is merely transtemporal. Although it transports the faithful to the past through objects of Cuban history, there is no need to transport Cubans to the homeland, for one simply has to step outside the church. Thus Cubans on the island do not feel the need to assert their Cuban identity, for their identity has never been contested. They live in Cuba, so they are Cuban. Although the Virgin's feast day may provide a means for island Cubans to express a sense of pride in being Cuban, they do not necessarily feel the need to assert their Cubanness. Yet even if they did feel the need to reflect on what it means to be Cuban, the contemplation of identity is superceded by their struggle to survive economically on the island. Their economic struggles are the key reason that the Virgin's feast day celebration in El Cobre might be considered translocative. For those devotees who ask the Virgin for assistance in immigrating, the celebration can mentally transport them to the day when they are able to begin a new life in a new country, one they have never known. While Caridad is not a translocative symbol for island Cubans in the same way she is for exiles, the Virgin does possess the power to transport islanders to an imaginary life in the future.

It is precisely this ubiquitous desire to leave that concerns the bishops of Cuba. As they expressed in their pastoral letter, this desire reflects the need for change on the island. Their decision to release the letter on September 8 is not surprising, when one considers the historical relationship between the Virgin and Cuban struggles for liberty. 
Ten years after the release of El amor todo lo espera, the "Special Period" may have come to an end, but the political and economic situation condemned by the bishops in 1993 remains the same in many respects. As María Campistrous writes in an essay on the tenth anniversary of El amor todo lo espera (11):

In these ten years there have been changes, but the situation has visibly worsened.... Now, as then, we have to seriously ask ourselves: Why are there so many Cubans who want to leave and who do leave their homeland?... Ten years after that message full of new hopes, at times we feel tired, our illusions broken.... We want what does not exist and we hope for what we do not know how to build.

The words of Campistrous poignantly reveal the lack of hope among Cubans on the island today, one of the most significant reasons why many turn to La Caridad for inspiration in their struggles.

In La presencia social de la Iglesia, the Cuban bishops demand increased political, social, and economic freedoms, changes which can be achieved only through dialogue and reconciliation, not through confrontation. Although those who favor a violent overthrow of Castro's government may find the bishops' words weak, their decision to speak out must be commended. As the Archbishop of Miami writes, "I salute the bishops of Cuba for their forthright courage and pastoral leadership...I commend Cuba's bishops for their courage in speaking out, and the wisdom with which they do so....Cuba's church is neither silent nor weak" (Favalora 2).

Thus the politicization of the Virgin is not limited to the cries for Cuba libre heard for decades in Miami. In my opinion, the real political power of the Virgin's symbol lies in Cuba, not in exile. A future Cuba libre will be achieved by those who work for the goal within the island. Until that goal is achieved, exiles will certainly 
continue to collectively chant for the freedom of their homeland every year on September

8. But the real changes will come from within the island, and there is no doubt that the symbolic power of the Virgin of Charity will be invoked.

Regardless of the uncertain political future of Cuba, the celebrations of $\mathrm{La}$ Caridad this past year indicate that devotion to her will remain strong for years to come. Most likely, she will not become the Patrona de todos los inmigrantes in Miami, simply because most Catholic immigrants from other nations prefer their own Marian cults. Whatever the future holds for the cult of the Virgin of Charity, it is safe to say that Cubans on both sides of the Florida Straits will maintain the tradition of devotion, as long as mothers in Miami teach their daughters the importance of wearing yellow on September 8 and the words of $Y$ si vas a El Cobre..., as long as mothers in Cuba take their sons to the shrine in El Cobre to sit in front of the Virgin. It is images such as these that most powerfully reveal the cultural significance of La Caridad.

\section{INTERVIEWS}

Equally as powerful as images are the words of devotees. In the following section I will allow the faithful to speak for themselves. Unless otherwise stated, the overwhelming majority of my Miami interviewees are first-generation, white, Catholic, middle-class exiles, a reflection of the ermita's typical visitor. Although most left Cuba in the 1960 s, several of my interviewees immigrated more recently. While members of the first wave may never have returned to Cuba since the early 1960s, balseros were raised under the current system and understand the present situation of the island firsthand. This crucial difference must be kept in mind when considering my analysis of the interviews. 
My interviewees from the island represent more diverse sectors of Cuban society. Although all can be considered members of the lower class, they reflect the racial and religious diversity of the island. While some claim to be "pure" Catholics, many blend Catholic and African religious beliefs on a daily basis. Age is another important factor to consider, since those interviewees under the age of 45 have known only the current regime.

Although my questionnaire consisted of 32 questions in Miami and 25 questions in Cuba, I have chosen to focus on the following questions.

1. Why have you come to the shrine today?

2. What does the Virgin symbolize to you?

3. In what ways, if any, does Our Lady of Charity help you?

4. How do you define la cubanía?

5. In what ways, if any, is Our Lady of Charity connected with la cubania?

6. In your opinion, do Cubans who live in Cuba today/ exiled Cubans have the same degree of devotion to Our Lady of Charity?

7. What do you know about Ochún? Does she play a role in your devotion?

Why have you come to the shrine today?

Devotees of the Virgin in Cuba and Miami share several motivations for visiting the shrines in common, including gratitude, tradition, and health. Thankful for La Caridad's assistance with various problems in the past, the faithful often go to her shrines to express their profound gratitude. Many Cubans visit El Cobre to give thanks for the birth of healthy babies, such as Lola, a 22 year-old black female from Santiago, who came with her mother and newborn daughter, and Celia, a 27 year-old black female also from Santiago, who also came with a newborn son. In Celia's words, "About a year ago, I had a stillborn child. I made a promise to the Virgin that I would come here if I had a 
healthy baby. And here I am." Others come to give thanks for successful operations, such as Ibrahim, a 58 year-old white male. Similar sentiments of gratitude are often expressed in Miami. "I am a believer, and I am grateful," said Adela, an elderly white female who left Cuba in 1966. Adela has dressed completely in white every day for more than forty years, as a promise she made to the Virgin if her son arrived safely to the United States. He did, and she has worn white ever since, as an expression of her gratitude.

Tradition is also a common factor of motivation to visit the shrines. Enrique is a balsero who visits Miami's ermita every Sunday to express his gratitude to the Virgin for his safe journey to the United States. Other interviewees in Miami who habitually visit the shrine include Pablo, a 69 year-old white male who comes every day; Miguel, a 78 year-old retired white male who comes daily "to kill the time"; and Luisa, a 75 year-old white female who visits the shrine once a month to honor the memory of her recentlydeceased husband, who was profoundly devoted to the Virgin. Several of my interviewees in Cuba also visit the shrine in El Cobre on a regular basis, including Rosa, a white female in her mid 60s. "For the past two years, I have come every month," Rosa told me. "Today I came with my granddaughter, for her fifth birthday. We wanted her to meet the Virgin for the first time."

The shrines in both Miami and El Cobre attract many traditional Cuban Catholics, who consider themselves to be Catholic a mi propia manera, "in my own way." Although Miguel goes to the Miami ermita for Mass once in a while, he admits that "I am not a good Catholic. I don't like to follow the rules." Alberto also admits that "I may not be a proper Catholic. I don't go to Mass like I should, but I pray to the Virgin. I am 
Catholic in my own way." Visits to the Virgin's shrines thus enable such Catholics to maintain a connection to God, without following the traditional rules of the Catholic Church such as weekly Mass attendance.

Health concerns are another significant factor of motivation to visit the Virgin's shrines. As should be expected in a country affected by a severe lack of medicine and medical supplies, the health concerns of Cubans in El Cobre seem to be more prevalent than in Miami. Several of my interviewees told me about serious health problems in their families. Pilar is a black female with a 12 year-old daughter experiencing health problems due to malnutrition. Unemployed, Pilar comes to the shrine once a week from Santiago to pray to the Virgin for her daughter's health. "I am going through some hard times right now. My daughter is sick, she needs better nutrition. She is very sick, and I need the Virgin's help." Omara, a 73 year-old white female, is also concerned about the health of her family: "I came to pray for the health of my son, to give thanks for the birth of my great-granddaughter, and to pray for my grandson's operation. All of this is happening at the same time, so my head is a little crazy. But I have a lot of faith, and when I pray, I immediately feel better." Health concerns, of course, are not limited to Cuba. In addition to its location by the bay, another significant aspect of the ermita in Miami is its proximity to Mercy Hospital. Several interviewees in Miami expressed beliefs that the Virgin could help them with their health problems, including Francisco, an elderly second-wave exile whose favorite saint is San Lázaro. For matters of health, however, he always turns to La Caridad: "I came to ask her for health. I am very sick."

In terms of factors of motivation to visit the Virgin's shrines, the greatest difference between Miami and El Cobre is the politicization of the exiles' ermita. Many 
visit the shrine simply to express their hatred of Communism. In the words of Ester, a white female from Havana who came to Miami in 1970, "I am against the regime. That is the motive of all Cubans who come here." Or in the words of Ricardo, a white male who left Cuba in 1968: "Why did I come to the shrine? Simple. Porque no soy comunista." The same words, "because I am not a Communist," were also used by Esteban, a member of the first wave of exiles. As Alberto, a white male who left Cuba in 1969, told me, "I do not accept Communism....I am a lover of liberty." As the above descriptions reveal, those who come to the shrine to express their rejection of Communism share several characteristics in common: most are middle-class, white, Catholic, in their late $60 \mathrm{~s}$ or early $70 \mathrm{~s}$, and members of the first or second wave of exiles. None of those who left in the 1980s or 1990s expressed political motivations for visiting the shrine, perhaps a reflection of the increased level of tolerance for the current regime often expressed among this sector of exile. Unlike the "golden" exiles, those Cubans who left more recently -- primarily motivated by economic reasons -- have been raised within Castro's system. Consequently, they are less likely to express such an intense hatred of Communism.

Thus many of my interviewees did not come to express hatred of Castro. Rather they came simply to meditate, pray, and relax. "I came for peace and tranquility," said José, a 35 year-old white male who left Cuba in 1992. This desire for peace and tranquility was a common response among interviewees, as was the desire to be near the water. As María -- a white female who left Cuba at the age of 1 in 1967 -- told me, "I came to meditate, to look at the sea and be near the water." In the words of Carmen, a member of the second wave, "mentally the sea relaxes me." Thus one of the most 
significant aspects of the ermita in Miami is the sense of serenity that its location provides. This is another significant difference between Miami and El Cobre. Although several interviewees in Cuba told me they are devoted to the Virgin because she gives them inner peace, none said that the physical location of El Cobre provides a sense of tranquility. The mountains surrounding the shrine are certainly tranquil, yet the waters of Miami's Biscayne Bay seem to provide exiles with more profound feelings of peace -perhaps because of the unique relationship between islanders and the sea.

The shrine of El Cobre is significant in terms of both its geographic location and its spiritual significance. In the words of Herminia, a black female who volunteers at the shrine, El Cobre is "the heart of Cuba." Or as a deacon in the archdiocese of Santiago told me, the shrine is "the most magnetic place on the island. Like a magnet, it attracts Cubans from all parts." From across the island, devotees come to see La Caridad in person. Although the majority of devotees I interviewed at the shrine were from El Cobre or Santiago, a significant percentage comes from other parts of the island, despite the difficulties of transportation. Of my 25 interviewees, five were from other cities, including Havana, Matanzas, Pinar del Río, Camagüey, and Guantánamo. Alicia, for example, is a 36 year-old black female from Matanzas: "I came with a group of people from Matanzas by bus," she said. "This is truly an opportunity of a lifetime to see the Virgin in person." Sol, a 27 year-old black female, traveled to El Cobre from Pinar del Río, at the other end of the island. "This is my third time here," said Sol. "I come every few years because I need to see her." Although Cuban exiles from around the United States visit the ermita, the majority live in Miami. Of my 25 interviewees, only Alberto 
did not live in the area. He came from Union City, New Jersey for one reason only: "to show that I am a lover of liberty."

Of all the differences between Miami and El Cobre, the political nature of the exiles' sanctuary is definitely the most significant. Although there may be Cubans who travel to El Cobre simply to ask the Virgin for political change, the motivations of the majority are more immediate and practical. They come to pray for sick children, to give thanks for healthy babies, and to ask for help in the daily struggles of life. As Herminia told me in El Cobre, "We must endure daily the problems with our system. In Cuba there are some who live well, some live okay, but most are barely surviving. That is why we need the Virgin." Although some of the island devotees may share the exiles' hatred of Castro and his government, such political preoccupations are clearly superceded by concerns of survival.

What does the Virgin symbolize to you?

In both Miami and El Cobre, the majority of my interviewees expressed that La Caridad is the Mother of God and/or the Mother of Cubans. When asked what the Virgin symbolizes to them, about half of my interviewees immediately offered a theological interpretation of La Caridad as the Mother of Christ or the Mother of God. As Oscar, a white male who left Cuba at the age of two in 1962, told me, "first of all she is the mother of God, the most important person after Christ." Others offered a cultural interpretation of La Caridad as the Mother of all Cubans or the Patroness of Cuba. In the words of Alejandro, a white male who left Cuba in 1970, "She is our patroness. $99 \%$ of us, no -99.9\%, believe in her." Cubans in El Cobre also expressed similar sentiments, including Alberto, a deacon in the archdiocese of Santiago: "La Caridad is our patroness, both here 
and over there. She is a symbol of our identity." As the Patroness of Cuba, the Virgin is indeed a powerful symbol of national identity, a fact expressed by Cubans both in Miami and on the island. In the words of Herminia, the volunteer in El Cobre: "To say Cuba is to say the Virgin of Charity" Similar sentiments were expressed in Miami by Julia, a 63 year-old first-wave exile, who views the Virgin of Charity as "a flag for Cubans. She is like the star of our flag."

Thus Cubans on both sides of the Florida Straits believe that the Virgin is a symbol of national identity. As Olga Portuondo Zúñiga, the author of La Virgen de la Caridad del Cobre: Símbolo de cubanía, told me in a personal interview, La Caridad is "a way to affirm Cubanness." As mentioned previously, the need to affirm Cubanness is more prevalent in exile, away from the homeland. Thus Portuondo Zúñiga believes that "in Miami the Virgin takes on added significance because she symbolizes the homeland, the sentiments of patriotism, a form of national unity in the exterior. In this way, she possesses even more strength over there. The Virgin gives exiles strength and helps them to reaffirm their identity." The reaffirmation of Cubanness through La Caridad is thus possible because she symbolizes Cuba itself. For those Cuban Americans who have never been to Cuba, La Caridad also symbolizes a link to their Cuban heritage, as Teresa told me. A 17 year-old mulata who was born in the United States to a Cuban mother and Colombian father, Teresa is devoted to the Virgin because "she connects me to my ancestors. She reminds me of my grandparents; they always wore her symbol."

My interviews reveal that it is possible to simultaneously view La Caridad as both the Mother of God and the Mother of Cubans. Many Cubans interpret her in both a 
theological and cultural sense, including Jorge, a 60 year-old white male from Santiago, who believes that La Caridad symbolizes both the homeland and the faith of Cubans:

To me she symbolizes the combination of human history and the mystery of God, a mystery she unites with the Cuban nation. Like the flag, the hymn, the mariposa, the tambor, tobacco, rum, the guitar, she is a symbol of our patria. And even more than that, she symbolizes the faith that Cubans have in the progress of our lives.

Whether one chooses to interpret La Caridad as the Mother of God or the Mother of Cubans, the fact remains that she is a maternal figure. In the words of Lourdes, a 64 year-old white female who is a sister at the shrine in El Cobre, "She is our mother, present in all moments of our lives. She resolves all our problems." In Miami, Luisa believes that the Virgin is "like my own mother. In my most difficult moments, she is there." Or in the words of Victor, a 29 year-old black male from El Cobre, "She is an example of how to be a mother. That is the most beautiful thing about her, even for those who don't have faith." Victor raises an interesting point about the symbolic power of the Virgin: many Cubans who do not profess to have faith in God do express faith in La Caridad. Victor considers himself to be a Rastafarian, yet he prays to the Virgin every day. According to Felicia, a 62 year-old mulata who volunteers at the shrine, this phenomenon is common: "People come here with different ideologies, but here there is a sense of unity because everyone respects the Virgin. Some even come without faith, but even they experience something, an interior change. No one leaves the same as they entered." The fact that "faithless" Cubans have faith in La Caridad reveals that her symbolic power transcends the realm of the Catholic Church. For these Cubans, the Virgin is not the Mother of God, but a maternal figure who guides her children through 
the struggles of life. Thus I believe that La Caridad's universal appeal can be explained by the fact that she is a maternal figure.

As both a maternal figure and a symbol of the patria, La Caridad appeals to Cubans of all types: orthodox Catholics as well as atheists and the typical "in-my-ownway" Catholics. In the words of Julia in Miami, "most importantly, she is our mother. She is also like a flag...the most powerful symbol we have. She represents liberty, independence, faith for everyone: Communists, anti-Communists, the rich, the poor, people here, people over there." The Virgin's universal appeal is reflected in the words of Vilma, a 53 year-old mulata:

I am Catholic, but in my own way. I don't go to Mass every week, but I have a lot of faith in the Virgin. At least once a month, I dress all in yellow and go to El Cobre with my children. They are not religious, but even they like to go there because it makes them feel better, asking her for help. There are many people like that here, people who don't practice a religion, who say they don't have faith, but they do have faith in the Virgin. When they see her, they are moved. They know that she will help them.

Although the Virgin of Charity clearly does not appeal to all Cubans, especially Protestants, one cannot deny that she is embraced by Cubans of diverse political and religious ideologies. The following anecdote of Father José Conrado, pastor of Santa Teresita Parish in Santiago, reveals the extent of her appeal: "When I was in college, one day a professor, a known atheist, told me that 'I don't believe in God, but no one should mess with the Virgin of Charity." In this sense, Father Conrado agrees with Portuondo Zúñiga that La Caridad is a symbol of cubania, a fact which explains her wide appeal to Cubans of all ideologies. Yet during our interview, he stressed to me that "she is also something more. She transcends identity." In other words, there are essentially two 
fundamental ways to interpret the symbol of La Caridad. One can choose to view her as a symbol of cubania that transcends the realm of religion, or as a spiritual symbol that transcends the realm of national identity.

Of course, such a binary opposition is too simplistic an interpretation, for my interviews reveal that one can simultaneously believe that La Caridad is both the Mother of God and the Mother of Cubans. Thus the symbolic power of the Virgin lies in the fact that she is a maternal figure. As Father Conrado wrote in his own interpretation of the Virgin of Charity, she is a "symbol of communion for the Cuban nation." However, if one explores beyond the superficial ability of La Caridad to unify all Cubans, one will discover that she is simultaneously a symbol of unity and disunity. Although the Virgin may unify Cubans on both sides of the Florida Straits who believe that she is the Mother of God and/or the Mother of Cubans, not all Cubans share this belief. For many Cubans, La Caridad is not the Mother of God, but a wife of Changó, a fact which I will explore in subsequent pages. Furthermore, for some Protestant and Marxist Cubans, La Caridad may not be significant at all.

In what ways, if any, does Our Lady of Charity help you?

The strength of any religious symbol lies in its ability to meet the needs of the faithful. In the case of Cubans devoted to La Caridad, she meets various needs through her ability to provide inner strength, tranquility, hope, protection, guidance, maternal comfort, health, and prosperity. In times of great difficulty, Cubans on both sides of the Florida Straits often turn to the Virgin for the inner strength they need to face their problems. As Oscar told me in Miami, "she gives us strength to bear our crosses." In the

\footnotetext{
${ }^{30}$ José Conrado, Nuestra Señora de la Caridad del Cobre: Signo de communion para el pueblo cubano.
} 
words of Cristina, who left Cuba at the age of two in 1961: "In my most difficult moments, I ask the Virgin of Charity and she helps me." This ability of the Virgin to give inner strength to her devotees is crucial for those who must endure the struggles of exile. As Esteban told me, "I need her even more to deal with this, with exile. She helps me to face exile with faith." Cubans on the island also turn to La Caridad for the inner strength they need to face the many problems of a dying revolution. As Patricia told me in El Cobre, the Virgin is "like a crutch, a means of support, for those who need it. She listens to all our problems and gives us the strength we need to continue on."

Not only does La Caridad provide a sense of inner strength, but perhaps more importantly, a sense of hope to Cubans everywhere. In the words of Fernando, a 32 yearold white male who works for the Archbishop of Santiago:

In a situation like we have today, she is a source of economic, social, and political hope. Not only to Catholics, but to those without faith as well. She gives hope to everyone -- to Communists, to atheists, to all Cubans -because she can help us find a solution to our problems. In spite of all our discord, she unites us. Our faith in her continues today more than ever before.

Father Conrado also believes that one of the most significant aspects of the Virgin of Charity is her ability to inspire a sense of hope in spite of Cuba's many problems: "Above all, she sustains hope. She helps us to carry our crosses in life; she is a figure who alleviates burdens, especially in our country's situation." Cubans in Miami also look to the Virgin for a sense of hope that Cuba will one day be free. In the words of Carmen, who has not returned to the island since 1967, "whenever I feel hopeless, whenever I start to think that I may never return to see my country free, I ask the Virgin for help. She gives me hope that one day my homeland will be free." Devotees also 
believe that La Caridad will enable them to return to their island. As Ana told me, "she keeps up our hope that we will one day go back."

In addition to psychological needs, the Virgin of Charity also meets the more practical needs of her children, including health and prosperity. As Vilma told me in Cuba, "the Virgin keeps me healthy. I ask her above all for health. Because when you have health, you have everything." Some devotees also believe that the Virgin has the ability to provide economic prosperity. In the words of Maya, a white female who left Cuba in 1986, "She helps me with everything, my job, my health, my family. She gives me everything I need. I am happy. I have a job, a car, my health -- all because of her." Julia echoed similar sentiments: "Economically she responds to me very rapidly. When I am having money problems, things always seem to work out if I ask her for help." Although I expected many Cubans on the island to make similar economic requests -perhaps even to a greater extent than in Miami due to the severe financial problems of Cuba -- none of my interviewees stated that they turn to the Virgin for economic help. Instead, they are more likely to petition La Caridad for health and tranquility. As Ibrahím told me in El Cobre: "We don't come here asking for wealth. We come asking for tranquility, harmony, peace, satisfaction, solidarity, a sense of well-being. We just want to be comfortable in life." Perhaps Cubans on the island do not make economic petitions because they realize that any improvements in their economic situation must come from the government. Instead of asking the Virgin for wealth -- a goal they realize is not feasible, at least in the near future -- they ask for the psychological and physical wellbeing that is necessary to endure the daily struggles of life on the island. 
Others on the island, however, are fed up with such daily struggles. Instead of asking the Virgin for the strength they need to endure reality, they ask for her assistance in leaving Cuba. As Leo, a 30 year-old white male with an engineering degree who drives a taxi with a statue of La Caridad taped to his dashboard, told me, "I pray every day to the Virgin that one day I will live in Miami, every day. I plan to leave by boat -that may be dangerous I know, but it is more dangerous to live here. I know she will guide me." Simply put, the symbolic strength of the Virgin lies in the fact that she meets the diverse needs of her spiritual children, wherever they live. In the words of one of the religious sisters at the shrine in El Cobre, "the Virgin hears petitions, and listens to the needs of each individual." Despite the vastly different political, social, and economic conditions in which exiled and island Cubans live, their needs are essentially the same because they are the needs of all human beings. Regardless of where they live and what problems they are facing, all Cubans need strength to endure their struggles and hope that one day such struggles will end. It is precisely this sense of strength and hope that La Caridad provides to those who believe in her.

How do you define la cubanía?

In order to understand how the Virgin of Charity is a symbol of cubania, one must first understand the term itself. As mentioned previously, I believe there are several basic characteristics of cubanía: it is multidimensional, fluid, a choice, a contested concept, and most importantly, a matter of desire.

One of the most significant aspects of the Cuban spirit is its multidimensional nature. While I tend to associate the term with individual conceptions of identity, I realize that the historical and sociological aspects of cubanía cannot be ignored, as Olga 
Portuondo Zúñiga reminded me during our interview. When I asked the author to provide a definition of cubania in her own words, she replied that a concise definition is impossible because:

The topic of cubania is complex. There are different criteria.... Each generation has their own way of defining it. Today we define cubanía in terms of mestizaje, a mixed society. It is not easy to define the term, especially because each of Cuba's regions has its own identity....Identity itself is a complex process, so the term cubania can never be easily defined.

Although I agree with Portuondo Zúñiga that the complex, multidimensional nature of cubania prevents a concise definition, I believe that an exploration of individual definitions of the term reveals useful insights into the concept. The following definitions reveal that cubania is defined differently not only by each generation, but also by each individual.

The diversity of answers that I received reveals the complexity of the topic. In Miami, Julia defined la cubanía in one word: orgullo, or pride. Luisa believes that cubania means "respecting Martí, Maceo, all the patriots, the poets, having pride in our patria, respecting the flag....A Cuban is someone who believes in the homeland and feels proud." Several of my interviewees on the island also equated cubania with pride, but the word most often used to describe cubania was querer. Cubans both in Miami and on the island believe that love of the homeland is an essential aspect of being Cuban. In Miami, Eliana believes that to possess la cubania is querer a la patria, "to love the homeland." The same definition was used by Alberto on the island. The word querer has several meanings, including to love and to want. Regardless of where they live, I believe that most Cubans agree that both aspects of querer are equally significant 
components of cubania. To possess cubanía one must not only love the homeland, but also want to be Cuban. To be Cuban one must desire to be Cuban; one must choose to express cubanía.

This choice, of course, is perhaps more applicable to the exile experience. Although Cubans on the island and in exile may agree that querer is an essential aspect of cubania, the experience of exile has certainly altered perceptions of the term. While Cubans on the island do not have to make a conscious decision to be Cuban, those in exile must make the choice to express cubania. As Alberto told me, to be Cuban in exile means "to choose to never forget the past." María believes that "if you feel Cuban and you want to stay connected, you keep cubania alive in your heart." Her words reveal an important aspect of la cubania in exile: individuals must choose to maintain the connection to their homeland. As mentioned previously, one of the most powerful ways to maintain the connection is through the Virgin.

Another significant difference between island and exilic definitions of cubania is the sense of nostalgia reflected in the definitions of Miami Cubans. For Esteban, la cubania signifies "the palm tree, the beaches, the blue sky, the dear homeland." Furthermore, he equates cubania with querer libertad, the desire for liberty. This association between cubania and political freedom was not made by any of my interviewees on the island. Although many of them desire political freedom as much as their fellow Cubans in Miami, the term cubania does not quite have a political connotation on the island, at least for those whom I interviewed. Only in exile did this connotation emerge. 
The very fact that the concept of cubania has survived in exile reveals its fluidity. Identity can never be contained by geographical or political borders. Despite the physical absence of the homeland, cubania has survived in exile because its fluid nature allows it to transcend borders. Although the majority of my interviewees believe that a person must be born in Cuba to be Cuban, a view which I personally do not share, at the same time they believe that one does not have to live on the island to be Cuban. Their definition of what makes a person Cuban may be static in the sense that it is based on place of birth, but their conceptions of cubania are more dynamic. In the words of Luisa, "even in Alaska you can be Cuban. If there are five Cubans there, they will gather and have a party in the snow." Cubans on the island share the exilic belief that cubanía transcends the island. As Marta told me in El Cobre, "just because you move to a different country doesn't mean you lose your identity." Despite decades in exile, Cubans in Miami passionately maintain that they are Cuban. In the words of Ana, a 45 year-old white female who left the island at the age of 17: "I drive a Suburban, I listen to rock, I have an American flag in front of my home... but I am totally Cuban."

My own definition of cubanía extends its fluidity to another level. In my opinion, it is precisely the fluidity of identity which enables someone like myself to identify as "Cuban." If Ortiz is correct that cubania is not a matter of birth, but of desire, then my belief that I am Cuban should not be challenged. After all, it is my desire to be Cuban, and to intellectually explore my heritage, that has motivated this thesis. These pages are further proof that cubania cannot be limited to the island. I may have been born in Philadelphia and raised on a farm in northeastern Pennsylvania, but I feel Cuban. I therefore do not hesitate to consider myself Cuban because I possess the key ingredient of 
cubania: the desire to be Cuban. Although most of my interviewees would disagree that someone like myself can be Cuban simply because I was not born on the island, some did share my belief that a self-proclaimed Cuban does not have to be born in Cuba. As Julia told me in Miami, a Cuban is simply "someone who loves the island." In a similar sense, Adela believes that a person is Cuban "if they feel Cuban."

Conflicting opinions on the importance of one's place of birth are only one manner in which the term cubanía is contested. When asked if there are differences between the cubania of Cubans on the island and in exile, Miami Cubans revealed to me the contested nature of the term. Some believe that the difference between exiles and island Cubans is extreme, including Rafael who said that Cubans on the island "are different in every respect because forty years of Communism creates a different mentality." Pablo does not distinguish a Cuban's sense of cubanía by place of residence, but by year of birth. In his opinion, there are two types of Cubans: "those born before Fidel and those born after." Miguel also categorizes Cubans into two groups:

There are two types of Cubans: old Cubans and today's Cubans. They are completely different. Pardon me if I curse, but the others are mierda. They are trash. Morally and ethically we are different. Cubans like me -we made a life for ourselves. We were hard-working and wanted to forge ahead. But Cubans in Cuba today don't like to work. They work as least as possible because the system allows it. They are not professionals, and so when they come here, they don't work. They come just to receive economic aid, but don't work!

An important fact to consider is that Rafael, Pablo, and Miguel are all members of the first wave of exiles, which left Cuba in the early 1960s. Although their strong opinions may not represent the majority of this wave, they reflect not only the tension between Cubans on and off the island, but also the tensions among the different waves of Cubans 
in Miami. Their dichotomous categories of pre-/post-Fidel Cubans and cubanos viejos/actuales are clearly simplistic, but they reveal the contested nature of cubania. Keeping such tension in mind, the ability of any symbol -- including the Virgin -- to unify all Cubans is indeed questionable.

Some of my interviewees in Miami believe there is no difference between the cubania of island and exiled Cubans. As Ana told me, "A Cuban is a Cuban is a Cuban." Or as Julia said, "We are all Cuban." The majority in Miami, however, expressed their belief that the major factor of difference between exilic and island conceptions of cubanía is Cuba's political system. Exiles from all waves are united by the general consensus that four decades of Communism has affected conceptions of Cuban identity. Unlike Miguel, most exiles expressed a sense of sympathy for Cubans who must endure the difficulties of life on the island. The majority believe that Cubans on the island "are just as proud to be Cuban, but it is more difficult to be yourself over there," due to the lack of liberty. In a similar sense, Esteban describes the cubania of island Cubans as aplastada, or crushed, by the reality of life in a Communist country. Enrique, a balsero who understands this reality first-hand, also believes that the cubania of island Cubans is completely different "because of a lack of liberty." Maya, who left Cuba in 1986, believes that Cubans on the island do not think about concepts like cubania "because they think of survival only. They don't think about the bigger issues."

Maya raises a significant point about the concept of identity. For most Cubans on the island who must endure the difficulties of the Communist system, the contemplation of identity is clealy superceded by more practical concerns. How can people contemplate the definition of cubania when they must struggle daily to find food for their families? 
Despite the ubiquitous slogans encouraging Cubans to place the patria before all other concerns, the concerns of most are more practical. The failure of the government to meet the basic needs of many Cubans has thus affected expressions of cubania on the island. In other words, the desire to be Cuban is difficult to express when basic needs are not met.

Furthermore, the contemplation of cubania is unnecessary for Cubans on the island because their identity as Cubans has never been contested, as mentioned previously. Several of my interviewees in Cuba even laughed at the "silly" question of what makes a person Cuban. The majority share Lola's belief that the cubania of island and exiled Cubans is "similar, but different because of the age in which we live." Unlike exiles in Miami, Cubans on the island generally did not give lengthy answers to my questions about identity, perhaps because this is a topic which they do not need to contemplate.

In addition to class and location, an equally significant factor that explains the different interpretations of cubania is race. Yet another area of contention is the significance of Afro Cuban culture in conceptions of Cuban identity, an area which I will explore in subsequent pages. For now, it is sufficient to conclude that my personal definition of cubania was validated by the responses I received.

In what ways, if any, is Our Lady of Charity connected with la cubania?

The responses I received to this question reveal that devotion to La Caridad, like la cubania itself, is multidimensional, fluid, contested, a choice, and a matter of desire. In both Miami and El Cobre, many interviewees replied that the Virgin is inseparably connected to Cuban identity because she is the patroness of the island. As the patroness, 
La Caridad's role in Cuban history and culture has been multidimensional. In the words of Fernando, "she has been present in all our struggles for independence, ever since the birth of our nation, since the beginning of cubania. She will always be with us." Furthermore, the Virgin "unites all Cubans, both now and in the past," according to Eliana in Miami. Others replied that La Caridad and cubanía are "inseparable" and "completely connected. She is a fundamental part of our thinking." Some even believe that the Virgin is not a symbol of cubania, but is the Cuban spirit. As Ana told me in Miami, "You can't be a Cuban without the Virgin of Charity....She is la cubania."

Devotees in El Cobre share the general consensus of my Miami interviewees that La Caridad and cubania are inseparable. One of the volunteers in El Cobre, however, wanted to clarify that "the Virgin is not connected to Cuban identity. Cuban identity is connected to the Virgin. She existed before the concept of 'Cuban' identity, before the nation of Cuba itself." Most share Alberto's belief that "the Virgin implies cubanía. Because of that, El Cobre is the most magnetic place on the island. Like a magnet, it attracts Cubans from all parts."

Not everyone makes an association between the Virgin and Cuban identity, however. Rafael, for example, is a 58 year-old white male who goes to the Miami ermita regularly for confession only. In his own words:

I am not devoted to the Virgin. I am devoted to Christ. People here are ignorant....That is just a statue. It has no meaning....The Virgin is just an intercessor for Christ, a mediator.... Stories about the Virgin are beautiful but mean nothing.

Oscar, who left Cuba at the age of two, also does not make the connection between La Caridad and cubanía: "For me, she is not connected with Cuba, because I am 99\% 
American. I am not the typical visitor here. Most are older." Although these two views are definitely the minority, one must realize that the connection between La Caridad and Cuban identity is not automatic for all Cubans, especially for those who left the island at a young age like Oscar. While he considers himself to be devoted to the Virgin "as an avenue to Christ," he does not connect this devotion to his Cuban identity.

It is also crucial to realize that the connection between cubania and La Caridad is not significant for most members of the second generation of Cuban Americans, those born in the United States. Of my 25 interviewees in Miami, only two belong to this group. Although both Teresa and Maribel consider themselves to be devoted to the Virgin, they realize that they represent the minority among members of the second generation. As 17 year-old Teresa told me, "people my age are too caught up in today. They don't care about the past. My generation lives a different lifestyle. We are American." Most of my interviewees in Miami agreed with Teresa that members of the second generation are not as devoted to the Virgin of Charity as members of the first.

When considering the Virgin's role as a symbol of cubania, this decline in devotion is to be expected. Unlike members of the first generation who desire to stay connected to the past, most members of the second do not feel this need. As Americans, most do not share their parents' desire to be Cuban or to express cubania. Consequently, they do not feel such a need for La Caridad. Yet the fact that both Teresa and Maribel are devoted to the Virgin of Charity, despite the fact that they have never been to the island, reveals the fluidity of faith in the patroness, which cannot be contained by geographical borders. Thus devotion to the Virgin of Charity in exile is clearly a matter of individual choice, as is the desire to express cubania. 
In your opinion, do Cubans who live in Cuba today/ exiled Cubans have the same degree of devotion to Our Lady of Charity?

The majority of my interviewees in Miami believe that Cubans on the island have maintained devotion to the Virgin of Charity. Some like Ana base their opinions on firsthand observations made when they have visited the island in the past. "I saw it in my own family," she said. "I went to see them two years ago, and I was shocked to see so many statues in their homes. I think devotion has increased a lot because of the Pope." Ana is one of the many exiles who immediately take relatives who have recently left the island to the shrine in Miami to give thanks for a safe journey. The desire of recentlyarrived immigrants to go the ermita is another reason why many of my interviewees believe that devotion on the island has been maintained. As Elsa told me, "yes, the devotion is the same because those who just arrive always come here." Luisa agrees that the degree of devotion is the same in Cuba because "there has been an opening of the Church. People can now publicly show their faith, and I have read that the churches there are always filled on September 8th."

Others believe that although the degree of devotion may be similar, religious restrictions on the island must be taken into consideration. "Perhaps they are just as devoted as we are, but it's not easy," said Ricardo. Enrique, a balsero, understands the difficulties of devotion first-hand. He believes that faith in the Virgin is just as intense on the island "but there are more restrictions there." Eliana agrees that devotion in Cuba "is difficult under the system. However, they seem to be opening their eyes." Julia also agrees that "they have not lost devotion, but it depends on how they've been raised." 
Other exiles, however, are not sure that devotion to the Virgin has been maintained on the island. Miguel is "not sure because I haven't been back." Others like Maria believe that faith in the Virgin is not as intense in Cuba because "they have been brought up differently. They don't have time to think about religion. They are thinking about what they are going to eat instead."

Meanwhile in El Cobre, most devotees believe that faith in the Virgin has been maintained by exiles in Miami. Some like Felicia are unsure because "I don't really know about those that live outside of Cuba. We don't get that kind of information, so I really can't answer that," but most believe that exiles are equally devoted to La Caridad. In the same sense that exiles believe that island Cubans have maintained devotion because they wish to immediately visit the Miami ermita after leaving Cuba, many devotees in El Cobre believe that exiles have maintained devotion because "those that return to Cuba often come here to give thanks that they were able to see their patria once again." Others base their belief that devotion is the same on "the fact that they constructed an ermita." Some like Fernando believe that faith in the Virgin has been maintained in exile because "she is the mother of all Cubans, and the Cuban nation is united, so of course they maintain devotion. We may be divided in the sense that there is much resentment on both sides, but that does not matter. What does matter is that devotion to the Virgin continues."

Padre Conrado shares the majority's belief that exiles are equally devoted to $\mathrm{La}$ Caridad, yet he makes an important distinction between the nature of devotion in Miami and Cuba: "In Miami the Virgin occupies an equally important place in the heart of exiles. For them, she is a link with the past, with their origins. But here she is a link to 
what we want to be, to our future, as well as a source of help and hope for those who wish to leave the island." Thus despite the fact that most of my interviewees believe that faith in the Virgin is equally intense in exile and on the island, the differences in the reasons for devotion cannot be ignored. Padre Conrado's belief that the exiles are devoted to a Virgin of the Past and those on the island to a Virgin of the Future may be too simplistic, but it does provide an insightful way to interpret the differences between exiled and island devotees. The intensity of devotion may be similar, but recognition of the differences is essential to truly understand the current significance of La Caridad. What do you know about Ochún? Does she play a role in your devotion?

One of the most significant differences in devotion to the Virgin of Charity in Miami and Cuba is the syncretic nature of belief on the island. Although Jorge and Isabel Castellanos estimate that one-third of visitors to the shrine in El Cobre are initiates of Santería, none of the Cubans whom I interviewed admitted to being an initiate. Based on Celia's appearance, I chose to interview her because I assumed she may have been initiated. A black female in her late 20 s, Celia was dressed completely in white, as Santeria initiands are expected to dress. Although I question whether or not she told me the truth, Celia emphasized that "I don't have faith in Ochún. I have faith in the Virgin."

About one-third of my interviewees admitted that Ochún does play a role in their devotion to the Virgin, most of them young black females such as Lola. "Ochún is the Virgin of Charity, the Virgin of love. They are the same, just a change in name," Lola told me. When I asked Patricia, a 36 year-old black female, if Ochún played a role in her devotion, she laughed. "Of course Ochún is part of my faith. Look at the color of my skin." Manuel, an 82 year-old black male from El Cobre, simply said "Como no...como 
no." Of course. Not all of my black interviewees, however, stated that Ochún plays a role in their devotion to La Caridad, including Pilar. A 43 year-old black female, she told me that "I don't believe in any of that." Although I have no way of verifying her statement, it is important to recognize that the color of one's skin does not necessarily reveal if a devotee believes in Ochún. I do recognize, however, that race is a crucial factor. None of my white interviewees in El Cobre admitted to being devoted to Ochún. Surprisingly, some of them had no idea who Ochún is. Of all my interviewees in Cuba, none expressed condemnation of syncretism or Santería -- unlike those in Miami, as I will soon demonstrate.

In an effort to understand how the Cuban Catholic Church deals with Santería, I asked Padre Conrado how the religion is viewed by Church officials like himself. "Syncretism is a historical fact, a symbol of the Cuban culture," he said. "To a certain point, Santería was logical, a way to escape religious persecution. Our hope in the Church is that the Virgin eliminates these mythological dimensions and that the people discover the truth who is Mary." In an effort to encourage practitioners of Santería to discover this "truth," those who visit the shrine in El Cobre are therefore not turned away. As one of the religious sisters at the shrine told me: "The Church is the mother of all, so the doors are always open here. Of course we see santeros dressed in white, but we don't turn them away. We hope and pray that they convert to the Virgin, but that is not a realistic goal for everyone." Practitioners of Santería in Miami, on the other hand, are often asked to leave the shrine. Although I am unsure how to explain this extreme difference in the treatment of santeros in El Cobre and Miami, it is one of the most significant differences between the two shrines. 
As should be expected due to the disproportionate number of exiles who are middle-class whites, the syncretic relationship between Ochún and the Virgin of Charity is significantly less prevalent in Miami. Of my 25 interviewees, only one admitted to practicing Santería. As mentioned in the section on Ochún, Teresa is a 17 year-old mulata who considers herself to be a daughter of Ochún. She does not distinguish between the goddess and the Virgin of Charity because "they are the same. Ochún is La Caridad. She's inside the shrine." Most of the other 24 interviewees recognized that Ochún "has something to do with Santería," yet that was often the extent of their knowledge. Ana recognized Ochún as "a santo, but I've never done anything with that. I know they're the same thing." Julia also recognized that Ochún "is the same...a fusion of traditions." José knew that "Ochún is the Virgin in Santería," but he stressed to me that "not all Cubans believe that. I don't." Most of the exiles admitted that they knew little about Santería. As Luisa told me, "I don't understand much about that, but it is syncretism....It is a religion I respect."

Other exiles in Miami, however, are not as tolerant of religious diversity as Luisa. Rafael, who believes that those who are devoted to the Virgin are ignorant, also believes that "Santería is plain ignorance, but slaves were smart to hide their beliefs." Eliana admits that "I don't like Santería," and Maribel believes that Santería is brujería, or witchcraft. According to Maribel, Santería is the reason why the dream of a Cuba libre has never been fulfilled:

One day the Virgin will free Cuba, but not until Cuba stops its idolatry. There is too much brujeria there. They're idolizing the wrong gods. They need to get their priorities straight. They have the wrong perspective....If they believed in the right God, then they would be free, but $80 \%$ of them pratice brujeria. 
While such a strong condemnation of Santería may not reflect the typical perspective of exiles, it clearly reveals the contested nature of cubania. Unless all Cubans learn to respect the many different ways to Cuban -- including the practice of Santeria, then both cubania and La Caridad will remain contested. If Cubans truly believe that the Virgin of Charity is the Mother of all Cubans, then they must also recognize that for many Cubans, she is both a Catholic virgin and the Yoruba goddess of love. 


\section{CHAPTER 7:}

\section{CONCLUSION: ¿Hasta cuando?}

For centuries, Cubans have looked to the Virgin of Charity for assistance in dealing with the struggles of slavery, independence, revolution, and exile. The symbolic power of her ability to meet the needs of her spiritual children cannot be denied. As a maternal figure, the strength of La Caridad lies in her ability to hear her children's diverse requests. As revealed in my historical analysis of devotion to the Virgin of Charity, her symbol has evolved to meet the needs of devoted Cubans for four centuries. I therefore accept my first hypothesis that La Caridad's symbolic strength has enabled her to meet the various needs of her spiritual children, whether those needs be religious, political, economic, or social. Her "resumé" is impressive: not only did she assist the royal slaves of El Cobre in achieving their freedom and guide the mambises on the path to independence from Spain, but she (as well as her counterpart Ochún) also continues to inspire in both exiles and island Cubans a sense of hope in the future. Thus La Caridad's role in the island's historical struggles for "liberty" in its many dimensions cannot be denied. The past evolution of her symbol clearly reveals both its power and plasticity.

In addition to meeting the various needs of her spiritual children, the Virgin of Charity has also reflected their desire to be "Cuban." Like La Caridad's myth, the concept of Cuban identity has evolved through the centuries, from the cobreros' attachment to the patria chica to the exiles' connection to a mythical homeland. As the idea of what it means to be "Cuban" evolved, so too did the symbol of La Caridad to reflect these changing conceptions of cubania. I therefore also accept my second hypothesis that the fluidity of her symbol reflects the fluidity of Cuban identity. Through 
an exploration of the Virgin's history and current significance, one can achieve a greater understanding of what it means to be Cuban.

Furthermore, as my thesis has revealed, the Virgin of Charity reflects the dynamic, complex, multidimensional, and fluid nature of cubania. As a symbol of Cuban identity, La Caridad reveals illuminating insights into the nature of what it means to be Cuban. Like identity itself, her symbol is complex and contested. Although some may invoke the Virgin as a means to unify all Cubans, the contested nature of her symbol clearly reveals that such unity is idealistic. As long as some Cubans believe that Santería is witchcraft, as long as some exiles believe that those on the island are trash, as long as some of those born on the island refuse to believe that I can be Cuban, the concept of cubania will remain contested. Furthermore, the belief that the Virgin is the Mother of all Cubans is idealistic when one takes into consideration the fact that not all Cubans believe in her symbol, especially the half a million Protestants on the island today. Thus although the Virgin may be a powerful symbol of Cuban national identity, devotion of $\mathrm{La}$ Caridad is clearly not essential in order to be Cuban.

As my analysis indicates, the association between cubania and the Virgin of Charity is more intense in the diaspora than on the island, due to the psychological difficulties of exile. In light of the disorientation experienced by exiles, the need to express cubania through devotion to the Virgin is understandable. Cubans on the island, however, do not turn to La Caridad to satisfy their collective nostalgia for prerevolutionary Cuba. Instead, they primarily seek support for the daily struggles they face, one of the most significant differences between devotion on the island and in exile. Perhaps four decades of revolutionary propaganda encouraging Cubans to place the 
patria ahead of all other concerns has ironically led to the opposite effect. Perhaps four decades of daily hardships and failed promises has affected the desire of Cubans on the island to express pride in being Cuban. In other words, it may be difficult to express cubania when one experiences constant hunger.

Although their motivations of devotion may differ greatly, devoted Cubans find in La Caridad a source of maternal comfort, spiritual solace, and most importantly, hope that the dream of Cuba libre will become a reality. Yet until their dream becomes a reality, faithful Cubans continue to place their hopes in La Virgen de la Caridad, asking her to end the daily struggles they face and to fulfill their desire for a free homeland. This desire is palpable when one observes devotees of La Caridad by the bay in Miami, contemplating the horizon beyond which lies their homeland, asking the same question they have asked for decades: ¿Hasta cuando? How long must we endure the struggles of exile? Ever hopeful that a Cuba libre is inevitable, exiles place their dreams of return at the feet of the Virgin, just as Cubans on the island place their dreams of escape. They too ask the same question: ¿Hasta cuando? How long must we endure the struggle to survive? In the words of Padre Conrado, "we must ask ourselves -- ¿hasta cuando? How long will people continue to risk their lives for a better future? When will the future we want be a reality?"

In a sense, the question ¿hasta cuando? is a unifying element of Cuban identity. Despite differences in race, class, gender, ideology, and residence, Cubans throughout history have been united by this question. How long must we endure slavery? How long must we remain a colony of Spain? How long must we remain in exile? How long must we struggle daily to find food for our families? As long as Cubans on the island and in 
exile ask how long they must wait for liberty, they will continue to seek comfort in the Virgin of Charity.

For now, Cuba libre is still a dream. When the dream does indeed become a reality, then one thing is definite: the myth of the Virgin will continue to evolve. Future stories of Cuba's patroness will emphasize her role in the demise of Communism, just as today's stories emphasize her role in achieving victory in the independence wars, in order to maintain the hope of liberation. Until the realization of the dream, however, many Cuban exiles will continue to share the hope expressed by Monsignor Román about future feast days of the Virgin: "We hope to celebrate it one day in El Cobre." Many Cubans in El Cobre, meanwhile, hope to celebrate the next September 8th in Miami.

Although the belief that she has the power to reconcile all Cubans is too idealistic and simplistic, I believe that reflections on her symbolic significance can lead Cubans to the beginning of the long and complex path of reconciliation. Perhaps the realization that Cubans are united by the question of ¿Hasta cuando? is the first step on this path. Furthermore, Cubans are united by the possession of cubania, the undeniable desire to be "Cuban," whatever that may mean for the individual. Understanding the multifaceted nature of Cuban identity is another essential step on the road to reconciliation. True reconciliation will be possible only when contested notions of Cuban identity are transcended, only when all Cubans affirm that an upper-class Catholic white male from Havana who now lives in Coral Gables is just as Cuban as a lower-class black female from Santiago who has an altar to Ochún in her home, or a middle-aged white female from Havana who recently converted to Protestantism, or a young black male from El Cobre who considers himself to be a Rastafarian but still believes in La Caridad. Or for 
that matter, an English-speaking, Pennsylvania-born, middle-class white female with a Cuban father and an Irish-American mother. Despite these radical differences in race, class, gender, age, and place of birth and residence, we are all "Cuban" in our own way. And somewhere in our homes, or in our wallets, or simply in our hearts, you will find La Caridad.

\section{$* * * * * *$}

Before leaving Cuba, I spent my final day conducting research in El Cobre. As I waited for my taxi to pick me up, I took a seat on a stone wall by the entrance to the shrine. Immediately a swarm of cobreros approached me, all begging me to buy a cheap wooden statue of the Virgin. Desperate for dollars, a few placed stones from El Cobre in my lap, expecting me to give them money in return. I gave the stones back, and told the group that I already bought my souvenirs.

Soon someone asked the unavoidable question, "Where are you from?"

"I'm American," I told the group. They all smiled, and told me how lucky I am. A young man jokingly, or perhaps not, asked me if I wanted to take home a Cuban husband, one of several proposals made to me during my time in Cuba, a reflection of the people's desperation to leave the island by any means possible.

"And how does an American like you learn to speak Spanish?" another young man asked me after I politely declined the marriage offer.

"I am Cuban," I told them. "My father is from Varadero."

“¿De verdad? Your father is Cuban? But you are not. You don’t speak Spanish like a Cuban, and you don't have Cuban eyes. Your father may be Cuban, but not you." 
"You are wrong," I wanted to say, "I am Cuban," but my taxi had arrived. I realized that no matter how much I may write about my intellectual quest to understand cubania, I will never be Cuban in the eyes of many, especially in the eyes of those Cubans who must endure daily the reality of the revolution. Although I may attempt to transcend the borders of identity through my words, the boundaries remain in the minds of many.

\section{$* * * * *$}

The following day, I returned home to Miami and saw the ermita from my airplane window, a destination that millions of Cubans on the island long to see with their own eyes. I realized how lucky I am to travel freely between both shrines, between the country of my birth and the island of my heritage. Like identity itself, I cannot be restricted by boundaries. I may not have been born on the island, but I am Cuban simply because I possess cubania. I may not be devoted to La Caridad, but you will find her image in my home, a reflection of both my respect for her symbolic power and my own desire to be "una cubana por excelencia,"31 just like Caridad.

\footnotetext{
${ }^{31}$ The Virgin of Charity was described as "una cubana por excelencia" by the independence war veterans in their petition to the Pope to declare her the island's patroness.
} 


\section{BIBLIOGRAPHY}

Acosta, Ikam. "Boy Exile Turned Saint: Elián González as a Contested ReligioIdeological Symbol among Cuban-American Catholics." M.A. Thesis, Religious Studies. Florida International University, 2001.

Anzaldúa, Gloria. Borderlands/La Frontera: The New Mestiza. 2nd ed. San Francisco: Aunt Lute Books, 1999.

Arrom, Juan José. "La Virgen del Cobre: historia, leyenda y símbolo sincrético." Certidumbre de América. $2^{\text {nd }}$ ed. Madrid: Editorial Gredos, 1971: 184-214.

Arzobispado de Santiago de Cuba. Iglesia en marcha. Año XII, No. 112 (Sept-Oct 2003).

Avis, Paul. God and the Creative Imagination: Metaphor, Symbol and Myth in Religion and Theology. NY: Routledge, 1999.

Badejo, Diedre L. Osun Seegesi: The Elegant Deity of Wealth, Power, and Femininity. Trenton: Africa World Press, 1996.

Bastide, Roger. African Civilisations in the New World. Transl. Peter Green. London: C. Hurst \& Co., 1971.

Belleli, Guglielmo and Mirella Amatulli. "Nostalgia, Imagination, and Collective Memory." Collective Memory of Political Events. Eds. James W. Pennebaker et al. Mahwah, NJ: Lawrence Erlbaum Associates, 1997.

Benítez-Rojo, Antonio. The Repeating Island: The Caribbean \& the Postmodern Perspective. Trans. James E. Maraniss. Durham: Duke UP, 1992.

Bidegain, Ana María. "Women and the Theology of Liberation." Through Her Eyes: Women's Theology from Latin America. Ed. Elsa Tamez. Maryknoll, NY: Orbis Books, 1989.

Boff, Leonardo. Introducing Liberation Theology. Transl. Paul Burns. Maryknoll, NY: Orbis Books, 1989.

---. The Maternal Face of God: The Feminine and its Religious Expressions. Transl. Robert R. Barr and John W. Diercksmeier. NY: Harper \& Row, 1987.

Boza Masvidal, Eduardo. Voz en el destierro. $2^{\text {nd }}$ ed. Miami: Trade Litho, Inc., 1976. 
Brandon, George. "Ochún in the Bronx." Osún Across the Waters: A Yoruba Goddess in Africa and the Americas. Eds. Joseph Murphy and Mei-Mei Sanford. Bloomington: Indiana UP, 2001: 155-64.

---. Santeria from Africa to the New World: The Dead Sell Memories. Bloomington: Indiana UP, 1997.

Cabrera, Lydia. Yemayá y Ochủn. NY: Eliseo Torres, 1980.

Campistrous, María C. "Diez Años Después." Iglesia en marcha. Año XII, No. 112 (Sept-Oct 2003): 9-11.

Castellanos, Isabel. "Four Women in the Life of Changó: The Semantic Complexity of Afro-Cuban Orishas." Apuntes Posmodernos/Postmodern Notes issues 6 \& 7: 30-38.

--- "A River of Many Turns: The Polysemy of Ochún in Afro-Cuban Tradition." Osún Across the Waters: A Yoruba Goddess in Africa and the Americas. Eds. Joseph Murphy and Mei-Mei Sanford. Bloomington: Indiana UP, 2001: 34-45.

Castellanos, Jorge and Isabel Castellanos. Cultura afrocubana. Vol. 3 and 4. Miami: Ediciones Universal, 1994.

--- and ---. "The Geographic, Ethnologic, and Linguistic Roots of Cuban Blacks." Cuban Studies vol 17 (1987): 95-110.

Christ, Carol P. "Why Women Need the Goddess: Phenomenological, Psychological, and Political Reflections." Womanspirit Rising: A Feminist Reader in Religion. Eds. Carol P. Christ and Judith Plaskow. NY: Harper Collins, 1992: 273-287.

Coriden, James A., et al, eds. The Code of Canon Law: A Text and Commentary. NY: Paulist Press, 1985.

Cuban Ecclesiastical Reflection Communities in the Diaspora. CRECED: Final Document. Transl. José Roig. Puerto Rico: Ramallo Brothers, 1996.

Curtin, Philip D. The Atlantic Slave Trade. Madison: University of WI Press, 1969.

Cutié, Alberto. "Haznos un solo pueblo bajo tu manto protector." La Voz Católica. 30 September 2002: 3 .

De Herrera-Vaillant, Antonio A. La Virgen de la Caridad del Cobre, El Hidalgo Sánchez de Moya y la supervivencia de Santiago de Cuba. Madrid: Hidalguía, 1982. 
De la Torre, Miguel. "Cubans in Babylon: Exodus and Exile." Religion, Culture, and Tradition in the Caribbean. Eds. Hemchand Gossai and Nathaniel Samuel Murrell. NY: St. Martin's Press, 2000: 73-94.

--.. "Ochún: (N)either the (M)Other of All Cubans (n)or the Bleached Virgin." Journal of the American Academy of Religion vol 69, no 4 (Dec. 2001): 837-861.

---. The Quest for the Cuban Christ: A Historical Search. Gainesville: UP of Florida, 2002.

De Rojas, Alma. "La cubanía in Exile." English Honors Thesis. Susquehanna University, 2002.

Desmangles, Leslie G. The Faces of the Gods: Vodou and Roman Catholicism in Haiti. Chapel Hill: University of North Carolina Press, 1992.

Díaz, María Elena. "Rethinking Tradition and Identity: The Virgin of Charity of El Cobre." Cuba, the Elusive Nation: Interpretations of National Identity. Eds. Damián J. Fernández and Madeline Cámara Betancourt. Miami: UP of Florida, 2000: 43-59.

---. The Virgin, the King, and the Royal Slaves of El Cobre: Negotiating Freedom in Colonial Cuba, 1670-1780. Stanford: Stanford UP, 2000.

Duany, Jorge. "From the Cuban ajiaco to the Cuban-American Hyphen." CSA Occasional Paper Series vol 2, no 8 (15 October 1997).

---. "Reconstructing Cubanness: Changing Discourses of National Identity on the Island and in the Diaspora during the Twentieth Century." Cuba, the Elusive Nation: Interpretations of National Identity. Eds. Damián J. Fernández and Madeline Cámara Betancourt. Miami: UP of Florida, 2000: 17-42.

Eliade, Mircea. Images and Symbols: Studies in Religious Symbolism. Transl. Philip Mairet. Princeton, NJ: Princeton UP, 1991.

Espín, Orlando O. "Popular Religion as an Epistemology (of Suffering)." Journal of Hispanic and Latino Theology vol 2, no 2 (1994): 55-78.

Farris Thompson, Robert. "Orchestrating Water and the Wind." Osün Across the Waters: A Yoruba Goddess in Africa and the Americas. Eds. Joseph Murphy and Mei-Mei Sanford. Bloomington: Indiana UP, 2001: 251-62.

Favalora, John C. "Pray for Cuba's Courageous Catholic Church." The Florida Catholic (18 Sept 2003): 2. 
Fernandes, Adolfo. "Mass Under Close Watch of Security Agents." Prima News 12 September 2002. www.prima-news.ru/eng/news/articles/2002/9/12/16784.html.

Fernández, Damián J. "Cuba and lo cubano, or the Story of Desire and Disenchantment." Cuba, the Elusive Nation: Interpretations of National Identity. Eds. Damián J. Fernández and Madeline Cámara Betancourt. Miami: UP of Florida, 2000: 7999.

--- and Madeline Cámara Betancourt. "Interpretations of National Identity." Cuba, the Elusive Nation: Interpretations of National Identity. Eds. Damián J. Fernández and Madeline Cámara Betancourt. Miami: UP of Florida, 2000: 1-13.

Flores-Peña, Ysamur. "Overflowing with Beauty." Osún Across the Waters: A Yoruba Goddess in Africa and the Americas. Eds. Joseph Murphy and Mei-Mei Sanford. Bloomington: Indiana UP, 2001: 113-127.

--- and Roberta J. Evanchuk. Santería Garments and Altars: Speaking Without a Voice. Jackson: UP of Mississippi, 1994.

Foskett, Mary F. A Virgin Conceived: Mary and Classical Representations of Virginity. Bloomington: Indiana UP, 2002.

Gebara, Ivone and Maria Clara Bingemer. Mary: Mother of God, Mother of the Poor. Transl. Philip Berryman. Maryknoll, NY: Orbis Books, 1989.

Greenfield, Sidney M. and André Droogers. "Recovering and Reconstructing Syncretism." Reinventing Religions: Syncretism and Transformation in Africa and the Americas. Eds. Sidney M. Greenfield and André Droogers. NY: Rowman \& Littlefield, 2001: 21-42.

Grenier, Guillermo and Lisandro Pérez. The Legacy of Exile: Cubans in the United States. NY: Pearson Education, 2003.

Hagedorn, Katherine J. Divine Utterances: The Performance of Afro-Cuban Santería. Washington, DC: Smithsonian Institution Press, 2001.

Hale, Lindsay. "Mama Oxum." Osún Across the Waters: A Yoruba Goddess in Africa and the Americas. Eds. Joseph Murphy and Mei-Mei Sanford. Bloomington: Indiana UP, 2001: 213-229.

Hall, Stuart. "Cultural Identity and Diaspora." Diaspora and Visual Culture: Representing Africans and Jews. Ed. Nicholas Mirzoeff. NY: Routledge, 2000: 21-33. 
Herskovits, Melville. "African Gods and Catholic Saints in New World Negro Belief." American Anthropologist vol 39, no 4. (Oct-Dec 1937): 635-643.

Johnson, Elizabeth. "Mary of Nazareth: Friend of God and Prophet-Indeed, what is a woman? And who gets to decide?" America 17 June 2000.

Johnson, Paul C. "Kicking, Stripping, and Re-Dressing a Saint in Black: Visions of Public Space in Brazil's Recent Holy War." History of Religions vol 37, no 2 (Nov 1997): 122-141.

Kirk, John M. Between God and the Party: Revolution and Politics in Revolutionary Cuba. Tampa: University of South Florida Press, 1989.

Knight, Franklin W. Slave Society in Cuba during the Nineteenth Century. Madison: University of WI Press, 1970.

Lachatañere, Rómulo. "Las religiones negras y el folklore cubano." Revista Hispánica Moderna vol 9 (Jan-Apr 1943): 138-43.

Machado Ribeiro dos Santos, Ieda. "Nesta Cidade Todo Mundo e d'Oxum." Osún Across the Waters: A Yoruba Goddess in Africa and the Americas. Eds. Joseph Murphy and Mei-Mei Sanford. Bloomington: Indiana UP, 2001: 68-83.

Marrero, Leví. Cuba: Economía y sociedad. Vol. 5. Madrid: Editorial Playor, 1976.

---. Los esclavos y la Virgen del Cobre: Dos siglos de lucha por la libertad. Miami: Ediciones Universal, 1980.

Marx, Karl. Early Writings. NY: Vintage Press, 1979.

McManus, Jim. All Generations Will Call Me Blessed: Mary at the Millenium. NY: The Crossroad Publishing Co., 1999.

Mensajero de la paz y la esperanza: Textos de la visita de Su Santidad Juan Pablo II a Cuba. Miami: Ediciones Universal, 1998.

Morgan, David. Visual Piety: A History and Theory of Popular Religious Images. Los Angeles: University of California Press, 1998.

Murphy, Joseph M. Santería: An African Religion in America. Boston: Beacon Press, 1988.

--.. "Yéyé Cachita: Ochún in a Cuban Mirror." Osún Across the Waters: A Yoruba Goddess in Africa and the Americas. Eds. Joseph Murphy and Mei-Mei Sanford. Bloomington: Indiana UP, 2001: 87-101. 
--- and Mei-Mei Sanford. "Introduction." Osún Across the Waters: A Yoruba Goddess in Africa and the Americas. Eds. Joseph Murphy and Mei-Mei Sanford. Bloomington: Indiana UP, 2001: 1-27.

Murray, Mary. "Cuban Church Challenges Castro." 10 September 2003. www.msnbc.com/news/ntbk_front.asp.

Nagle, Robin. Claiming the Virgin: The Broken Promise of Liberation Theology in Brazil. NY: Routledge, 1997.

Narbutas, Titas. Marian Shrines of the Americas. NY: Vantage Press, 1968.

Neville, Robert Cummings. The Truth of Broken Symbols. Albany: SUNY Press, 1996.

Ortiz, Fernando. "Los factores humanos de la cubanidad." Orbita de Fernando Ortiz. Ed. Julio Le Riverend. Havana: UNEAC, 1973: 149-157.

Palmié, Stephan. Wizards and Scientists: Explorations in Afro-Cuban Modernity and Tradition. Durhahm: Duke UP, 2002.

Pérez, Lisandro. "The Catholic Church in Cuba: A Weak Institution." Puerto Rican and Cuban Catholics in the US, 1900-1965. Eds. Jay Dolan and Jaime Vidal. Notre Dame: University of Notre Dame Press, 1994: 147-157.

Pérez Firmat, Gustavo. The Cuban Condition: Translation and Identity in Modern Cuban Literature. NY: Cambridge UP, 1989.

---. "A Willingness of the Heart: Cubanidad, Cubaneo, Cubanía." Cuban Studies Association Occasional Paper Series vol 2, no 7 (October 1, 1997).

Pérez y Mena, Andrés. "Cuban Santería, Haitian Vodun, Puerto Rican Spiritualism: A Multiculturalist Inquiry into Syncretism." Journal for the Scientific Study of Religion vol 37, no 1 (March 1998): 15-27.

Poole, Stafford. Our Lady of Guadalupe: The Origins and Sources of a Mexican National Symbol, 1531-1797. Tuscon: University of Arizona Press, 1995.

Portuondo Zúñiga, Olga. La Virgen de la Caridad del Cobre: Símbolo de cubanía. Santiago de Cuba, Editorial Oriente, 1995.

Poviones-Bishop, María del Pilar. "The Braids of the Virgin: Taino Roots of the Early Cult of La Virgen de la Caridad del Cobre in Cuba." M.A. Thesis, Religious Studies. Florida International University, 2002. 
Ramos, Marcos Antonio. Panorama del Protestantismo en Cuba. San José: Editorial Caribe, 1986.

---. Protestantism and Revolution in Cuba. Miami: Research Institute for Cuban Studies, 1989.

Ramos, Miguel "Willie." "Afro-Cuban Orisha Worship." Santería Aesthetics in Contemporary Latin American Art. Washington DC: Smithsonian Institution Press, 1996: 51-76.

Rey, Terry. Our Lady of Class Struggle: The Cult of the Virgin Mary in Haiti. Trenton: Africa World Press, 1999.

--.. "The Politics of Patron Sainthood in Haiti: 500 Years of Iconic Struggle." The Catholic Historical Review. vol 88, no 3. (July 2002): 519-545.

---. "The Virgin's Slip is Full of Fireflies': The Multiform Struggle Over the Virgin Mary's Legitimierende Macht in Latin America and its U.S. Diasporic Communities." U.C. Davis Law Review vol 33, no 4 (Summer 2000): 955-972.

Rodríguez, Jeanette. Our Lady of Guadalupe: Faith and Empowerment Among Mexican-American Women. Austin: Univ. of Texas Press, 1994.

Román, Monsignor Agustín. "La Virgen de la Caridad en el Centenario de la República de Cuba." La voz católica (May 2002).

Sandoval, Mercedes Cros. La religión afrocubana. Madrid: Playor, 1975.

---. "Santería." J. Florida M.A. vol 70 no 8 (August 1983): 620-28.

---. "Santería as a Mental Health Care System: An Historical Overview." Social Science and Medicine vol 13 (1979): 137-51.

Shaw, Rosalind and Charles Stewart. "Introduction: Problematizing Syncretism." Syncretism/Anti-Syncretism: The Politics of Religious Synthesis. Eds. Charles Stewart and Rosalind Shaw. NY: Routledge, 1994.

Skorupski, John. Symbol and Theory: A Philosophical Study of Theories of Religion in Social Anthropology. NY: Cambridge UP, 1976.

Stevens-Arroyo, Anthony M. "The Contribution of Catholic Orthodoxy to Caribbean Syncretism: The Case of la Virgen de la Caridad del Cobre in Cuba." Arch. de Sc. Soc. des Rel. vol 117 (Jan-Mar 2002): 37-58. 
--. "The Evolution of Marian Devotionalism within Christianity and the IberoMediterranean Polity." Journal for the Scientific Study of Religion vol 37, no 1 (1998): 50-73.

--. "Latino Catholicism and the Eye of the Beholder: Notes Towards a New Sociological Paradigm." Latino Studies Journal vol 6, no 2 (May 1995): 22-55.

Tirado Torres, Brenda. "Pasión por el Evangelio." La voz católica (August 2003): 4-5.

Tweed, Thomas. Our Lady of the Exile: Diasporic Religion at a Cuban Catholic Shrine in Miami. NY: Oxford UP, 1997.

Underwood, John. "Exiles Pray for End of Tyranny." The Miami Herald. 9 September 1961. p. 1A, 2A.

United States Department of State. "International Religious Freedom Report 2002:

Cuba." www.state.gove/g/drl/rls/irf/2002.

Warner, Marina. Alone of All Her Sex: The Myth and the Cult of the Virgin Mary. NY: Vintage Books, 1983.

Weber, Max. The Sociology of Religion. Boston: Beacon Press, 1993.

Wright, Irene. "Our Lady of Charity." Hispanic American Historical Review vol 5, no 4. (November 1922): 709-717. 


\section{APPENDIX 1}

\section{Cubania and Caridad}

English-language version of the Structured Interview Questions

Miami FL

Today's Date:

1. Male Female

2. Where do you live now? City

3. In what year were you born? Country

4. In which country were you born?

5. If you were born in Cuba, in which municipality were you born?

6. If you were not born in the United States, in which year did you arrive in this country?

7. Why have you come to the shrine today?

8. How long have you been devoted to Our Lady of Charity?

9. Please tell me about where your devotion to Our Lady of Charity began.

10 . What does the Virgin symbolize to you?

11. In the United States, has your devotion to La Caridad increased, decreased, or remained the same? If it has increased, in what way?

12. Why are you devoted to Our Lady of Charity?

13. In what ways, if any, does Our Lady of Charity help you? (Have you ever made a promise to her? If yes, could you please describe?)

14. How important is this devotion to you?
a. Not important at all
b. Not very important
c. Somewhat important
d. Very important

15. How do you express your devotion to Our Lady of Charity?
a. Daily masses
b. Rosaries
c. Annual rosary and mass on September 8
d. Personal devotions
e. Other:

16. Do you have symbols of La Caridad at home? Do you wear any symbols of La Caridad?

17. In your own words, can you tell me the story of La Caridad? Who were "los tres Juanes?"

18. In what way and to what extent is devotion to Our Lady of Charity connected with your beliefs and feelings about Cuba?

19. In your opinion, will La Caridad affect the future of Cuba? If so, how?

20. In what way, if any, is your devotion to Our Lady of Charity connected with your Cuban identity?

21. How do you do identify yourself?
a. Cuban 
b. Cuban American

c. Other:

22. Has life in the United States changed your feelings about your Cuban identity? If so, how?

23. How do you define la cubanidad/la cubanía?

24. Does la cubanidad/la cubanía affect your personal life, and if so, how?

25. In what way, if any, is Our Lady of Charity connected with la cubanidad/la cubania?

26. In your opinion, does the second generation of Cuban Americans (those who were born in the United States or who arrived when very young) have the same degree of devotion to Our Lady of Charity? Why or why not?

27. In your opinion, do Cubans who live in Cuba today have the same degree of devotion to Our Lady of Charity?

28. What makes a person Cuban?

29. To be Cuban, do you need to live in Cuba? Why or why not?

30. Is the cubania of people who live on the island different from the cubania of exiles?

31. What do you know about Ochún? Does she play a role in your devotion?

32. What is your attitude about contemporary Cuba? 


\section{APPENDIX 2}

\section{Cubanía and Caridad}

English-language version of the Structured Interview Questions

Santiago de Cuba

Today's Date:

33. Male__ Female

34. Where do you live now? City

35 . In what year were you born?

36. In which municipality were you born?

37 . Why have you come to the shrine today?

38. What does the Virgin symbolize to you?

39. How long have you been devoted to Our Lady of Charity?

40. Please tell me about where your devotion to Our Lady of Charity began.

41. Why are you devoted to Our Lady of Charity?

42. In what ways, if any, does Our Lady of Charity help you?

43. How important is this devotion to you?
a. Not important at all
b. Not very important
c. Somewhat important
d. Very important

44. How do you express your devotion to Our Lady of Charity?
a. Daily masses
b. Rosaries
c. Annual rosary and mass on September 8
d. Personal devotions
e. Other:

45. Do you have symbols of La Caridad at home? Do you wear any symbols of La Caridad?

46. In your own words, can you tell me the story of La Caridad? Who were "los tres Juanes?"

47. In what way and to what extent is devotion to Our Lady of Charity connected with your beliefs and feelings about Cuba?

48. In your opinion, will La Caridad affect the future of Cuba? If so, how?

49. In what way, if any, is your devotion to Our Lady of Charity connected with your Cuban identity?

50. How do you define la cubanidad/la cubania?

51. Does la cubanidad/la cubania affect your personal life, and if so, how?

52. In what way, if any, is Our Lady of Charity connected with la cubanidad/la cubania?

53. In your opinion, do exiled Cubans have the same degree of devotion to Our Lady of Charity?

54. What makes a person Cuban?

55. To be Cuban, do you need to live in Cuba? Why or why not? 
56. Is the cubania of people who live in Cuba different from the cubania of exiles? 57 . What do you know about Ochún? Does she play a role in your devotion? 